\title{
Effects of edge and coarse woody debris on small mammal communities in riparian and upland habitats in northern West Virginia
}

Joseph Daniel Osbourne

West Virginia University

Follow this and additional works at: https://researchrepository.wvu.edu/etd

\section{Recommended Citation}

Osbourne, Joseph Daniel, "Effects of edge and coarse woody debris on small mammal communities in riparian and upland habitats in northern West Virginia" (2002). Graduate Theses, Dissertations, and Problem Reports. 1534.

https://researchrepository.wvu.edu/etd/1534

This Thesis is protected by copyright and/or related rights. It has been brought to you by the The Research Repository @ WVU with permission from the rights-holder(s). You are free to use this Thesis in any way that is permitted by the copyright and related rights legislation that applies to your use. For other uses you must obtain permission from the rights-holder(s) directly, unless additional rights are indicated by a Creative Commons license in the record and/ or on the work itself. This Thesis has been accepted for inclusion in WVU Graduate Theses, Dissertations, and Problem Reports collection by an authorized administrator of The Research Repository @ WVU. For more information, please contact researchrepository@mail.wvu.edu. 
Effects of Edge and Coarse Woody Debris on Small Mammal Communities in Riparian and Upland Habitats in Northern West Virginia

Joseph Daniel Osbourne

Thesis submitted to the

Davis College of Agriculture, Forestry, and Consumer Sciences

at West Virginia University

in partial fulfillment of the requirements

for the degree of

\author{
Master of Science \\ in \\ Wildlife and Fisheries Resource Management
}

James T. Anderson, Ph.D., Major Advisor

John W. Edwards, Ph.D.

Laurence B. Williams, M.S.

Division of Forestry

Morgantown, West Virginia

2002

Keywords: Abundance, Coarse Woody Debris, Diversity, Edge,

Interior, Riparian, Small Mammal, Upland

Copyright 2002 Joseph D. Osbourne 


\section{ABSTRACT \\ Effects of Edge and Coarse Woody Debris on Small Mammal Communities in Riparian and Upland Habitats in Northern, West Virginia}

\section{Joseph Daniel Osbourne}

The effects on biological communities of human-induced disturbances such as road construction for logging and military activities are a topic of much controversy in modern society. Furthermore, the response of small mammal communities to edge and coarse woody debris (CWD) volume in riparian and upland habitats of the central Appalachian Mountains has received little attention. The objectives of this study were to: 1) Perform a faunal survey of the Camp Dawson Collective Training Area in Preston County, West Virginia with an emphasis on rare and endangered species, 2) Estimate small mammal abundance, diversity, and condition in response to CWD manipulation, and 3) Compare small mammal abundance, diversity, and condition in edge and interior locations of riparian and upland habitats. Shannon diversity was higher in riparian $(\bar{x}=1.79, \mathrm{SE}=$ $0.04)$ than upland $(\bar{x}=1.62, \mathrm{SE}=0.05)$ habitats $(P=0.024)$ and also appeared higher in edge $(\bar{x}=1.74, \mathrm{SE}=0.05)$ than interior $(\bar{x}=1.61, \mathrm{SE}=0.06)$ trapping locations $(P=$ $0.050)$. Species richness was higher in riparian $(\bar{x}=9.71, \mathrm{SE}=0.31)$ than upland $(\bar{x}=$ $8.71, \mathrm{SE}=0.35)$ habitats $(P=0.038)$. Individual species' response to edge, $\mathrm{CWD}$, and habitat type varied. Habitat type and location are important in determining the composition of small mammal communities, while CWD manipulation has little effect on small mammal abundance, diversity, or condition. 


\section{ACKNOWLEDGMENTS}

I thank the following individuals for their assistance with the field sampling conducted for this project: Bryan E. Adams, Collins K. Balcombe, Jason M. Calhoun, David A. Helon, Sheri L. Helon, Joshua B. Johnson, Jennifer M. Menzel, M. Alex Menzel, Sheldon F. Owen, Todd J. Polesiak, N. Scott Riley, Jeff Simcoe, H. Wayne Weaver, Michael M. Whitmore, Jennifer L. Wykle, and Andrew K. Zadnik.

A special thanks is extended to George E. Seidel, C. Robert Long, and Gregory M. Forcey for assistance with statistical analysis. Special thanks also is extended to my graduate committee, in particular my advisor James T. Anderson, for advice, support, and the opportunity to conduct this research. I also thank the West Virginia Army National Guard, West Virginia University (WVU) Research Corporation, and the WVU Agricultural and Forestry Experiment Station for funding and resources.

Finally, I thank my family and friends for loving support through the trials and tribulations of life. I couldn't have done it without you! 


\section{TABLE OF CONTENTS}

CHAPTER I. LIST OF TABLES...............................................................................

CHAPTER I. LIST OF FIGURES...........................................................................

CHAPTER II. LIST OF TABLES........................................................................vii

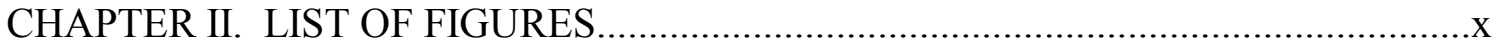

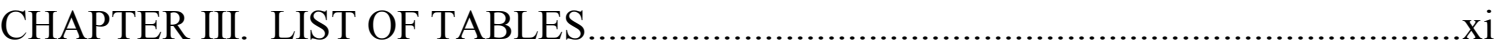

LIST OF APPENDICES...........................................................................................

CHAPTER I....................................................................................................................................1

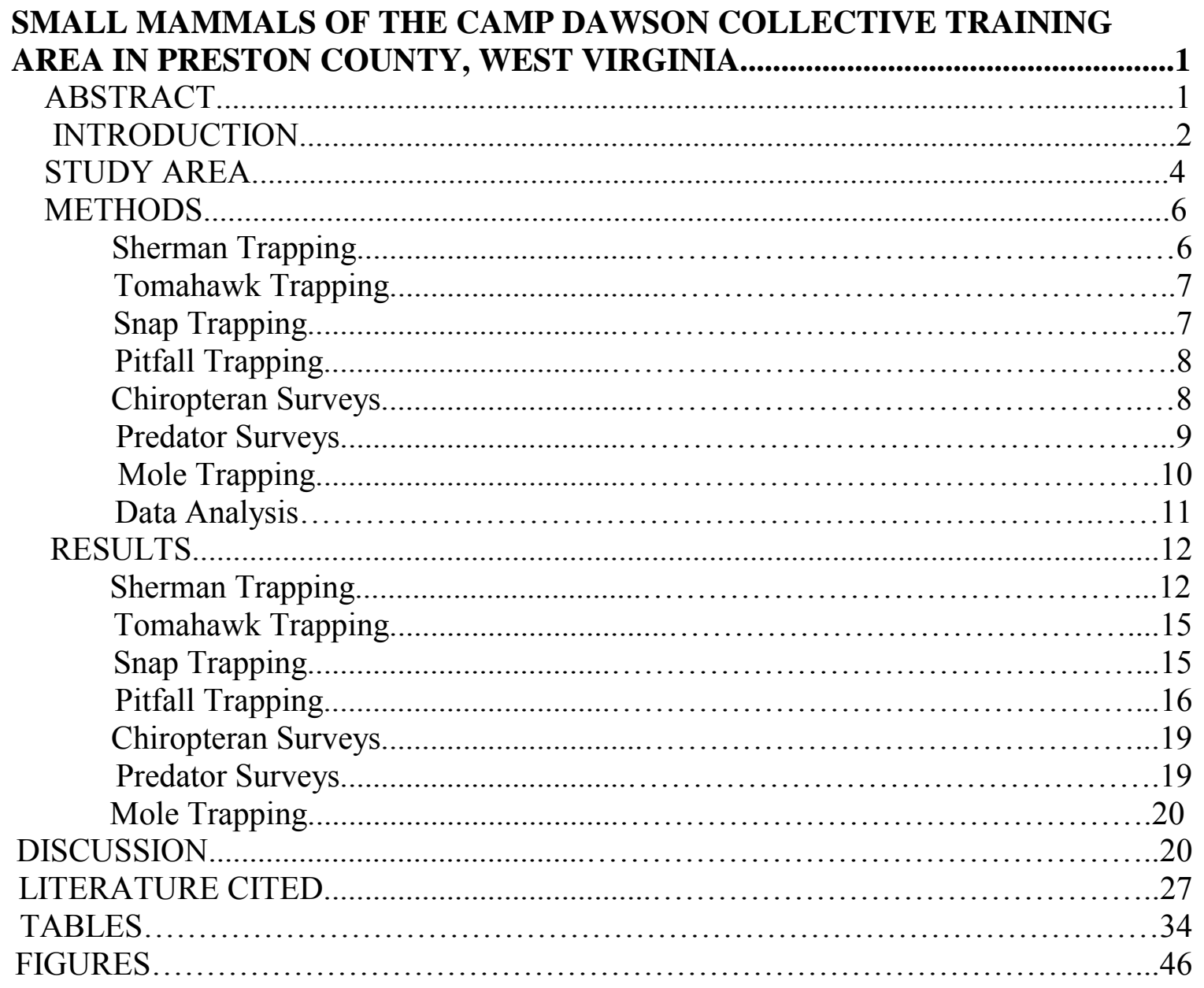




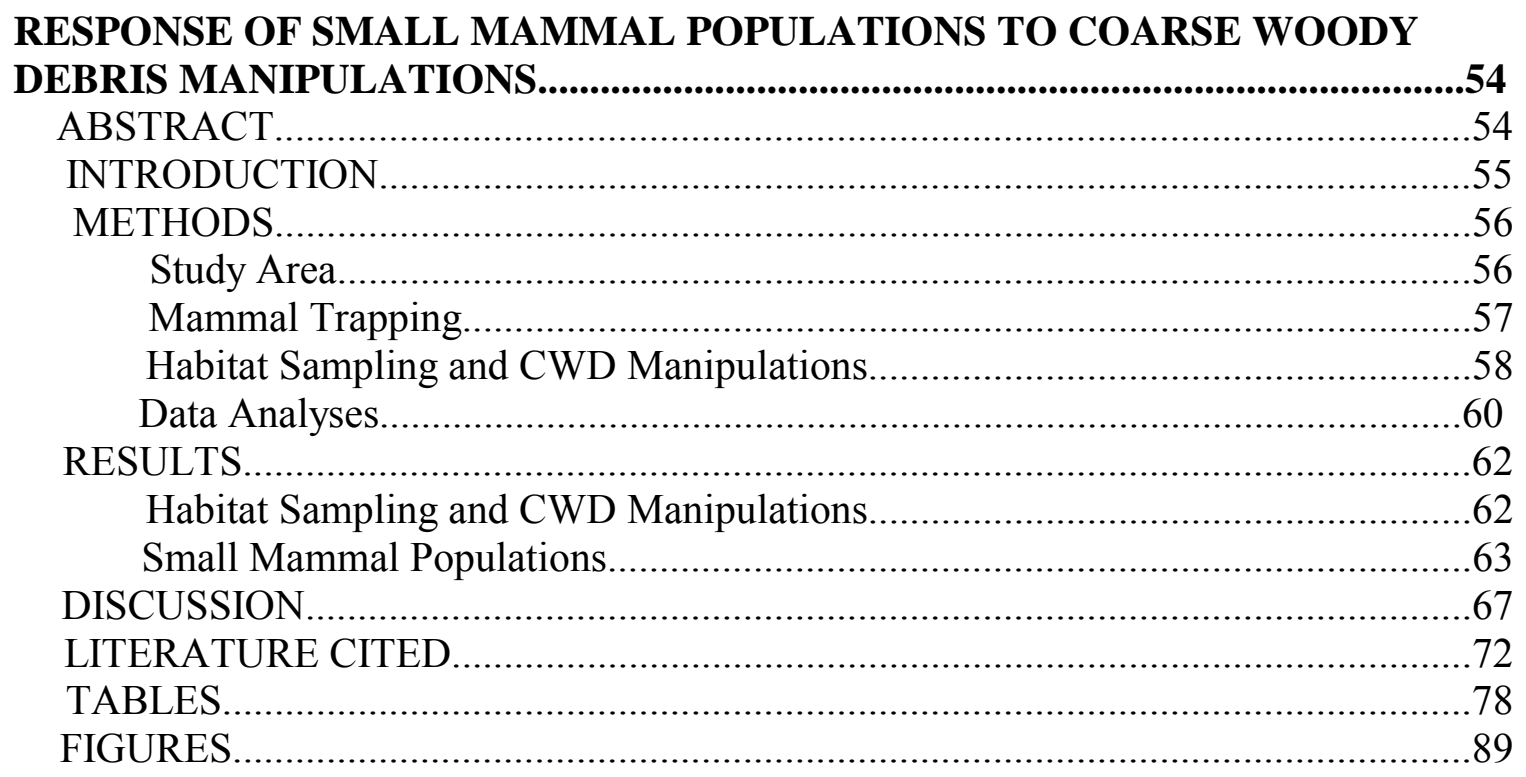

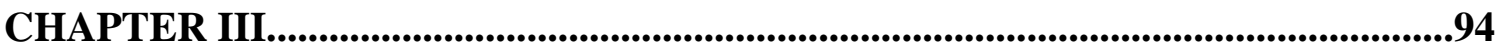

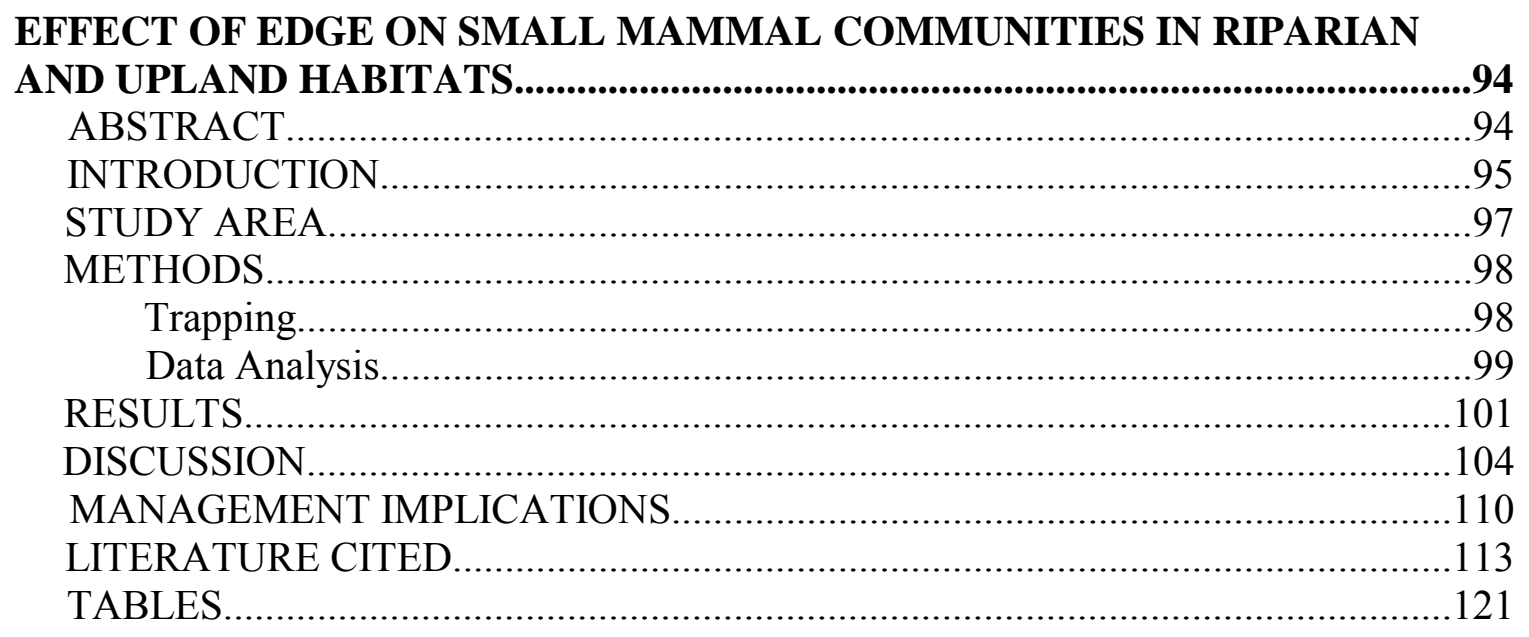

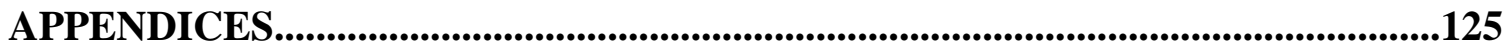




\section{CHAPTER I. LIST OF TABLES}

Table 1. Mammalian species listed on the West Virginia Rare Species List with global and state rank (WVDNR 2000). Species in bold were documented on the Camp Dawson Collective Training Area in Preston County, West Virginia during 2000 and 2001..........34

Table 2. Relative abundance of mammalian species observed on the Camp Dawson Collective Training Area (CDCTA) in Preston County, West Virginia during 2000 and 2001. Species with an * were captured on the CDCTA, and relative abundance for these species was calculated using number of individuals captured. For species observed but not captured relative abundance was based on frequency of observation.

Table 3. Captures per 100 trap nights for species captured in Sherman live trapping grids on the Cantonment Area (CA) and Pringle Tract (PT) of the Camp Dawson Collective Training Area in Preston County, West Virginia during 2000 and 2001

Table 4. Captures per 100 trap nights, Shannon diversity, Pielou evenness, and species richness for small mammals captured in pitfall trapping arrays on the Camp Dawson Collective Training Area in Preston County, West Virginia during 2000 and 2001

Table 5. Shannon Diversity, Pielou's Evenness Index, Species Richness, Sorenson Community Similarity Index, and number of arrays by vegetative community (Vanderhorst 2001) for small mammals captured in pitfall traps on the Camp Dawson Collective Training Area in Preston County, West Virginia during 2000 and 2001

Table 6. Mean number of calls recorded per monitoring session with test values for Chiropteran species captured on the Camp Dawson Collective Training Area in Preston County, West Virginia during 2000 and 2001

Table 7. Mammals and birds recorded at scent stations on the Camp Dawson Collective Training Area in Preston County, West Virginia during 2000 and 2001. 45 


\section{CHAPTER I. LIST OF FIGURES}

Figure 1. The Camp Dawson Collective Training Area in Preston County, West Virginia.

Figure 2. Locations of Sherman live trapping grids on the Pringle Training Area of the Camp Dawson Collective Training Area in Preston County, West Virginia during 2000 and 2001. Sites in blue were trapped once in 2000 and not selected for this study. Sites in red were selected and trapped in 2000 and 2001. Sites in yellow were added in 2001

Figure 3. Locations of Allegheny Woodrat (Neotoma magister) trapping sites on the Pringle Training Area of the Camp Dawson Collective Training Area in Preston County,

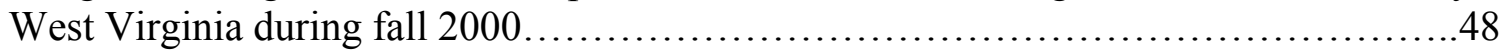

Figure 4. Locations of Tomahawk live trapping grids and Museum Special snap trapping grids on the Camp Dawson Collective Training Area in Preston County, West Virginia during 2000 and 2001. Sites in blue are Tomahawk grids trapped in 2000. Sites in yellow are Tomahawk trapped in 2001. Sites in black are snap trap grids trapped in 2000.

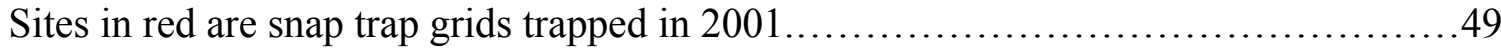

Figure 5. Locations of pitfall trapping arrays on the Camp Dawson Collective Training Area in Preston County, West Virginia during 2000 and 2001. Sites in red were trapped in 2000 and 2001. Sites in yellow were trapped in 2001.

Figure 6. Diagram of pitfall arrangements used on the Camp Dawson Collective Training Area in Preston County, West Virginia during 2000 and 2001. Full arrays have 4 drift fences and 5 pitfall buckets. Transect arrays have 1 fence and 4 pitfall buckets.

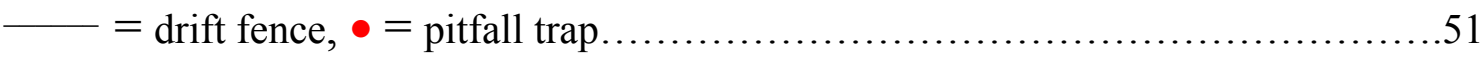

Figure 7. Shannon Diversity Index values by vegetative community for small mammals caught in pitfall traps on the Camp Dawson Collective Training Area during 2000 and 2001

Figure 8. Buffer zones around trapping locations where West Virginia state rare mammal species were captured on the Camp Dawson Collective Training Area in Preston County, West Virginia during 2000 and 2001 (WVDNR 2000)....................................53 


\section{CHAPTER II. LIST OF TABLES}

Table 1. Average vegetative characteristics for addition $(\underline{\mathrm{N}}=6)$, removal $(\underline{\mathrm{N}}=6)$ and control $(\underline{\mathrm{N}}=6)$ coarse woody debris $(\mathrm{CWD})$ manipulation grids on the Camp Dawson Collective Training Area in Preston County, West Virginia during 2000 and

2001

Table 2. Captures per 100 trap nights for the 5 most abundant species and diversity estimates for small mammals captured in addition $(\underline{\mathrm{N}}=4)$, removal $(\underline{\mathrm{N}}=4)$, and control $(\underline{N}=4)$ coarse woody debris $(C W D)$ manipulation classes and edge $(\underline{N}=8)$ and interior $(\underline{N}=4)$ trapping sites before CWD manipulations on the Camp Dawson Collective Training Area in Preston County, West Virginia during 2000 and 2001

Table 3. Captures per 100 trap nights for the 5 most abundant species and diversity estimates for small mammals captured in addition $(\underline{N}=6)$, removal $(\underline{N}=6)$, and control $(\underline{N}=6)$ coarse woody debris $(C W D)$ manipulation classes and edge $(\underline{N}=10)$ and interior $(\underline{\mathrm{N}}=8)$ trapping sites before CWD manipulations on the Camp Dawson Collective Training Area in Preston County, West Virginia during 2000 and 2001

Table 4. Captures per 100 trap nights and diversity estimates for small mammals captured in addition $(\underline{\mathrm{N}}=4)$, removal $(\underline{\mathrm{N}}=4)$, and control $(\underline{\mathrm{N}}=4)$ coarse woody debris $(C W D)$ manipulation classes and edge $(\underline{N}=8)$ and interior $(\underline{N}=4)$ trapping sites after CWD manipulations on the Camp Dawson Collective Training Area in Preston County, West Virginia during 2000 and 2001.

Table 5. Captures per 100 trap nights for the 5 most abundant species and diversity estimates for small mammals captured in addition $(\underline{\mathrm{N}}=6)$, removal $(\underline{\mathrm{N}}=6)$, and control $(\underline{N}=6)$ coarse woody debris $(\mathrm{CWD})$ manipulation classes and edge $(\underline{\mathrm{N}}=10)$ and interior $(\underline{\mathrm{N}}=8)$ trapping sites after CWD manipulations on the Camp Dawson Collective Training Area in Preston County, West Virginia during 2000 and 2001

Table 6. Average mass (g), ratio of males to females, and proportion of reproductive females for Peromyscus spp. captured in addition $(\underline{N}=4)$, removal $(\underline{N}=4)$, and control $(\underline{N}=4)$ coarse woody debris $(C W D)$ manipulation classes and edge $(\underline{N}=8)$ and interior $(\underline{\underline{N}}=4)$ trapping sites before CWD manipulations on the Camp Dawson Collective Training Area in Preston County, West Virginia during 2000 and 2001 
Table 7. Average mass (g), ratio of males to females, and proportion of reproductive females for Peromyscus spp. captured in addition $(\underline{N}=6)$, removal $(\underline{N}=6)$, and control $(\underline{N}=6)$ coarse woody debris manipulation classes and edge $(\underline{N}=10)$ and interior $(\underline{N}=8)$ trapping sites before CWD manipulations on the Camp Dawson Collective Training Area in Preston County, West Virginia during 2000 and 2001

Table 8. Average mass (g), ratio of males to females, and proportion of reproductive females for Peromyscus spp. and Blarina brevicauda captured in addition $(\underline{N}=4)$, removal $(\underline{N}=4)$, and control $(\underline{N}=4)$ coarse woody debris $(\mathrm{CWD})$ manipulation classes and edge $(\underline{N}=8)$ and interior $(\underline{N}=4)$ trapping sites after CWD manipulations on the Camp Dawson Collective Training Area in Preston County, West Virginia during 2000 and 2001

Table 9. Average mass (g), ratio of males to females, and proportion of reproductive females for Peromyscus spp. and northern short-tailed shrews (Blarina brevicauda) captured in addition $(\underline{\mathrm{N}}=6)$, removal $(\underline{\mathrm{N}}=6)$, and control $(\underline{\mathrm{N}}=6)$ coarse woody debris manipulation classes and edge $(\underline{\mathrm{N}}=10)$ and interior $(\underline{\mathrm{N}}=8)$ trapping sites after $\mathrm{CWD}$ manipulations on the Camp Dawson Collective Training Area in Preston County, West Virginia during 2000 and 2001 


\section{CHAPTER II. LIST OF FIGURES}

Figure 1. Abundance of Peromyscus spp. on addition, removal and control coarse woody debris manipulation sites in 2 statistical models on the Camp Dawson Collective Training Area in Preston County, West Virginia during 2000 and 2001. Data from 6 trapping sessions from the 12 grids manipulated in 2000 were used for analysis in Model I, and data from 2 trapping sessions from the 12 grids manipulated in 2000 and 4 trapping sessions from the 6 grids manipulated in 2001 were used for analysis in Model II. The same letter above standard error bars indicate no difference for that model $(\underline{\mathrm{P}}>$ $0.05)$

Figure 2. Abundance of Peromyscus spp. by trapping session in addition $(\underline{\mathrm{N}}=4)$, removal $(\underline{\mathrm{N}}=4)$, and control $(\underline{\mathrm{N}}=4)$ coarse woody debris manipulation classes on the Camp Dawson Collective Training Area in Preston County, West Virginia. Trapping session 1 was conducted before manipulations in the summer of 2000. The line represents the trapping session conducted within 24 hours of manipulations. The other 5 trapping sessions were conducted after manipulations

Figure 3. Captures per 100 trap nights $(\mathrm{TN})$ by trapping session in addition $(\underline{\mathrm{N}}=4)$, removal $(\underline{\mathrm{N}}=4)$, and control $(\underline{\mathrm{N}}=4)$ coarse woody debris manipulation classes on the Camp Dawson Collective Training Area in Preston County, West Virginia. Trapping session 1 was conducted before manipulations in the summer of 2000. The line represents the trapping session conducted within 24 hours of manipulations. The other 5 trapping sessions were conducted after manipulations

Figure 4. Relative abundance of Southern Red-backed Vole (Clethrionomys gapperi) in addition, removal and control coarse woody debris (CWD) manipulation classes of edge and interior forest trapping sites on the Camp Dawson Collective Training Area in Preston County, West Virginia during 2000 and 2001. Different letters above standard error bars indicate different values $(\underline{\mathrm{P}}<0.05)$

Figure 5. Average species richness by trapping session in addition $(\underline{\mathrm{N}}=4)$, removal $(\underline{\mathrm{N}}=$ 4 ), and control $(\underline{N}=4)$ coarse woody debris manipulation classes on the Camp Dawson Collective Training Area in Preston County, West Virginia. Trapping session 1 was conducted before manipulations in the summer of 2000. The line represents the trapping session conducted within 24 hours of manipulations. The other 5 trapping sessions were conducted after manipulations. 


\section{CHAPTER III. LIST OF TABLES}

Table 1. Average relative abundance in captures per 100 trap nights (CPU), species richness, Pielou's Evenness Index, Shannon Diversity Index, average mass (g), ratio of males to females, and proportion of reproductive females values for small mammal species captured in pitfall traps in riparian and upland habitats and edge and interior trapping locations on the Camp Dawson Collective Training Area in Preston County, West Virginia during 2000 and 2001 


\section{LIST OF APPENDICES}

Appendix Ia. Mammalian species with range maps overlapping the Camp Dawson Collective Training Area (CDCTA) in Preston County, West Virginia (Burt and Grossenheider 1980, Merritt 1987, Wilson and Reeder 1993). Species in bold are listed as rare or endangered by the West Virginia Division of Natural Resources (2000). Species with an * were observed on the CDCTA during 2000-2001....

Appendix Ib. Total number of mammalian species captured on the Camp Dawson Collective Training Area in Preston County, West Virginia during 2000 and 2001

Appendix IIa. Vegetative characteristics measured at Sherman live trapping grids on the Camp Dawson Collective Training Area in Preston County, West Virginia during 2000 and 2001. Coarse Woody Debris (CWD) volumes are reported before and after manipulation of CWD. ( $\mathrm{A}=$ Addition Site, $\mathrm{R}=$ Removal Site, $\mathrm{C}=$ Control site)

Appendix IIb. Captures per 100 trap nights (CPU) for small mammal species captured in sampling grids stratified by addition $(\underline{N}=6)$, removal $(\underline{N}=6)$, and control $(\underline{N}=6)$ coarse woody debris $(\mathrm{CWD})$ manipulation classes, edge $(\underline{\mathrm{N}}=10)$ and interior $(\underline{\mathrm{N}}=8)$ trapping locations, and riparian $(\underline{\mathrm{N}}=9)$ and upland $(\underline{\mathrm{N}}=9)$ habitats

Appendix IIc. Test values for the interaction terms of coarse woody debris (CWD) by location of trapping grid (edge/interior), CWD by trapping session, and CWD by location by trapping session for captures per 100 trap night (CPU) values of the 5 most abundant species, total CPU, and diversity indices of small mammals captured in addition, removal, and control CWD manipulation trapping grids on the Camp Dawson Collective Training Area in Preston County, West Virginia during 2000 and 2001. Data are from 2 different statistical models.

Appendix IId. Test values for the interaction terms of coarse woody debris (CWD) by location of trapping grid (edge/interior), CWD by trapping session, and CWD by location by trapping session for average mass (g), ratio of males to females, and proportion of reproductive females of Peromyscus spp. and Blarina brevicauda captured in addition, removal, and control CWD manipulation trapping grids on the Camp Dawson Collective Training Area in Preston County, West Virginia during 2000 and 2001. Data are from 2 different statistical models

Appendix IIIa. Average relative abundance in captures per 100 trap nights (CPU) for small mammal species captured in pitfall traps in riparian and upland habitats and edge and interior trapping locations on the Camp Dawson Collective Training Area in Preston County, West Virginia during 2000 and 2001 
Appendix IIIb. Average relative abundance in captures per 100 trap nights (CPU), species richness, Pielou's Evenness Index, and Shannon Diversity Index for small mammal species captured in pitfall traps in riparian edge (RE), riparian interior (RI), upland edge (UE), and upland interior (UI) locations on the Camp Dawson Collective Training Area in Preston County, West Virginia during 2000 and 2001. Test values are for the interaction of habitat (riparian and upland) and location (edge and interior)......139

Appendix IIIc. Average mass (g) of the 5 most abundant species captured in pitfall traps in riparian edge (RE), riparian interior (RI), upland edge (UE), and upland interior (UI) locations on the Camp Dawson Collective Training Area in Preston County, West Virginia during 2000 and 2001. Test values are for the interaction of habitat (riparian and upland) and location (edge and interior).

Appendix IIId. Ratio of males to females for the 5 most abundant small mammals captured in pitfall traps in riparian edge (RE), riparian interior (RI), upland edge (UE), and upland interior (UI) locations on the Camp Dawson Collective Training Area in Preston County, West Virginia during 2000 and 2001. Test values are for the interaction of habitat (riparian and upland) and location (edge and interior).

Appendix IIIe. Proportion of reproductive females and test values for the 5 most abundant small mammals captured in pitfall traps in riparian edge (RE), riparian interior (RI), upland edge (UE), and upland interior (UI) locations on the Camp Dawson Collective Training Area in Preston County, West Virginia during 2000 and 2001. Test values are for the interaction of habitat (riparian and upland) and location (edge and interior). Different letters represent statistical difference for that comparison $(\alpha=$ $0.05)$ 


\section{CHAPTER I}

SMALL MAMMALS OF THE CAMP DAWSON COLLECTIVE TRAINING AREA IN PRESTON COUNTY, WEST VIRGINIA

Abstract: Mammalian surveys were conducted on the Pringle Training Area (TA), Briery Mountain TA, and Cantonment Area installations of the Camp Dawson Collective Training Area (CDCTA) in Preston County, West Virginia during 2000 and 2001 as part of a faunal survey of the military installation. Small mammals were sampled using Sherman live traps, Tomahawk live traps, Museum Special snap traps, pitfall arrays, and Victor mole traps. Mist nets and call detection were used to sample Chiropterans, and carnivores were surveyed with scent stations. A total of 6,696 mammals of 30 different species were collected across all trapping methods. In 2001 the average captures per 100 trap nights (CPU) value for the Pringle TA $(\bar{x}=34.96, \mathrm{SE}=$ 1.95) was higher than the value for the Cantonment Area $(\bar{x}=23.05, \mathrm{SE}=1.83)(P<0.001)$. Average CPU values for snap trapping (year: $P=0.588$ ) and pitfall trapping (year: $P=0.141$, tract: $P=0.177$ ) were similar between years and tract of land. Average CPU for Peromyscus spp. (White-footed Mice [P. leucopus] and Deer Mice [P. maniculatus] ) was higher on the Pringle TA $(\bar{x}=2.63, \mathrm{SE}=0.33)$ than the other 2 tracts of land $(P<0.004)$. Woodland Jumping Mice (Napaeozapus insignis) produced higher CPUs on the Pringle TA $(\bar{x}=1.62, \mathrm{SE}=0.32)$ and the Cantonment Area $(\bar{x}=1.59, \mathrm{SE}=0.63)$ than the Briery Mountain $\mathrm{TA}(\bar{x}=0.13, \mathrm{SE}=$ $0.03)(P<0.001)$. Shannon diversity was higher on the Pringle TA $(\bar{x}=1.78, \mathrm{SE}=0.04)$ than the Briery Mountain TA $(\bar{x}=1.50, \mathrm{SE}=0.07)(P<0.026)$. Four species from the West Virginia Department of Natural Resources Rare Species List were captured on the CDCTA: Long-tailed Shrew (Sorex dispar), Allegheny Woodrat (Neotoma magister), Southern Bog 
community composition and species distribution among tracts likely was due to differences in habitat type, habitat quality, and human disturbance.

PROCEEDINGS OF THE WEST VIRGINIA JOURNAL OF SCIENCE 00(0):000-000

Key words: abundance, diversity, Masked Shrew, Northern Short-tailed Shrew, Peromyscus spp., small mammals, Smoky Shrew, Woodland Jumping Mouse.

Mammals are vital components of eastern deciduous forest environments. These vertebrates contribute to the overall diversity of life forms and provide valuable functional diversity (Chew 1976, Carey and Johnson 1995, Loeb 1999, Butts and McComb 2000). Small mammals of the orders Insectivora and Rodentia are prey for many avian, mammalian, and reptilian predators (Ryszkowski et al. 1973, Fedriani et al. 2000, Molsher et al. 2000, Lekunze et al. 2001). Additionally, many shrews and mice feed on insects, plants, seeds, fruits, and fungi that can potentially alter and dominate forest ecosystems (Platt and Blakey 1973, Elliot 1974, Chew 1976, French et al. 1976, Carey and Johnson 1995, Liebhold et al. 2000). Small mammals provide many benefits to ecosystem function, and enumeration of these species is important for monitoring the existence of a diverse small mammal community.

Information on mammal distribution in Preston County, West Virginia is scarce, and no previous faunal surveys have been conducted on the Camp Dawson Collective Training Area (CDCTA) properties. Range maps of mammals in the eastern United States were analyzed from several references to comprise a list of species with range maps overlapping the study site (Burt and Grossenheider 1980, Merritt 1987, Wilson and Reeder 1993, Whitaker 1996) (Appendix Ia). The Virginia Opossum (Didelphis virginiana) is the only marsupial predicted to occur on the CDCTA (scientific names follow Wilson and Reeder 1993). Of North American Insectivores, 7 
shrew species (Soricidae) and 3 mole species (Talpidae) are possible inhabitants of the study site. Ten Chiropteran species listed in Merritt (1987) have range maps that overlap the study area. Rodentia is the order with the largest number of species (21) that might exist on the study site. There are 13 Carnivores and 1 Artiodactylid that occur in West Virginia. This provides a total of 59 mammalian species that could occur on the CDCTA. The West Virginia Division of Natural Resources (WVDNR) lists 10 of the aforementioned species as rare, but only the Indiana Bat (Myotis sodalis) and the Gray Bat (M. grisescens) are federally endangered (WVDNR 2000) (Table 1). The other rare species and subspecies listed are all common globally, but rare in certain parts of their range. Several of the species are not likely to occur on the study site, but could possibly be in the area if habitat is suitable.

This study incorporates several facets of mammal monitoring and management into a collaborative project. One way of increasing efficiency of scientific study in a field with limited funding and resources is by incorporating several different studies into 1 collection event (Carey and Johnson 1995, Menzel et al. 1999). This study will provide the baseline for a mammalian monitoring program that maintains natural diversity and effective use of resources on the CDCTA.

Faunal assessment helps determine the degree that local wildlife populations are affected by anthropogenic disturbances. Acid mine drainage, strip mines, and army training occur on the CDCTA, and have varying affects on local wildlife. These anthropogenic factors have lead to forest fragmentation, degradation of water quality, increase of edge habitat, and associated loss of interior wildlife habitat. Information collected from this study was used by the Natural Resources Program Staff of the CDCTA to develop an Integrated Natural Resources Management Plan as required under the Sikes Act (16 USC 670a et seq.). 
The primary objective of this study was to provide baseline faunal data to determine which species occur on the CDCTA. Specific objectives were to:

1) Develop a list of mammalian species that occur on the CDCTA;

2) Determine relative abundance and distribution of small mammals found on the CDCTA;

3) Estimate diversity of small mammals on the CDCTA and use these data to compose a map of small mammal diversity by vegetative community type;

4) Determine small mammal community similarity among the different tracts of the CDCTA; and

5) Determine if any rare or endangered species occur on the CDCTA, and make management recommendations for these species.

\section{STUDY AREA}

The study was conducted on the Camp Dawson Cantonment Area, Briery Mountain Training Area (TA), and Pringle TA, which are installations in the CDCTA in Preston County, West Virginia (Figure 1). The CDCTA encompasses 1,655 ha and is primarily used for military training activities by the West Virginia Army National Guard (WVARNG) (WVARNG 2001).

The Cantonment Area comprises 378 ha and is located $6.4 \mathrm{~km}$ east of Kingwood, WV, about $39^{\circ} 26^{\prime}$ north latitude and $79^{\circ} 40^{\prime}$ west longitude, in the Dunkard Bottom of the Cheat River (WVARNG 2001). This is the main operating area for the West Virginia Army National Guard (WVARNG), and the property is primarily comprised of well maintained lawn, office buildings, an armory, vehicle maintenance buildings, a firing range, and a paved airstrip (USACHPPM 1994, WVARNG 2001). Heavily logged, forested mountain slopes and bottomland forest comprise the majority of the non-urbanized portion of the Cantonment Area. The primary cover types on the Cantonment Area are mixed mesophytic forest and successional 
floodplain forest (MRI 1994, USACHPPM 1994, Vanderhorst 2001, WVARNG 2001).

Elevations on the Cantonment Area range from 366 to $516 \mathrm{~m}$ above sea level. The primary soils on the property are silt and sandy loams (Bell 2001).

The Briery Mountain TA occupies about 423 ha and is located almost due east of the Pringle TA across the Cheat River about $39^{\circ} 24^{\prime}$ north latitude and $79^{\circ} 39^{\prime}$ west longitude (USACHPPM 1994). The predominant cover type on the Briery Mountain TA is mixed montane hardwood forest and sub-xeric Oak (Quercus spp.) forest (Streets 2001, Vanderhorst 2001). A small limestone quarry is located on the south end of the property. The elevation of Briery Mountain TA ranges from 579 to $853 \mathrm{~m}$ above sea level. The predominant soils on the property are loams, silt loams, and rubbly complexes (Bell 2001).

The Pringle TA is the largest of the 3 components of the CDCTA encompassing 854 ha. The Pringle TA is located on the northwest side of State Route 72 about $39^{\circ} 24^{\prime}$ north latitude and $79^{\circ} 42^{\prime}$ west longitude. The land use rights for the Pringle TA were leased to the WVARNG in 1996 by the owner of the property, Allegheny Wood Products, Inc (AWP). In exchange for the land rights, the WVARNG granted AWP timber rights for the Cantonment Area and Briery Mountain TA. In turn, all 3 tracts of land are heavily logged (WVARNG 2001). Pringle TA is predominately covered by Oak-Hickory (Carya spp.) forest, with the exception of several open, grassy reclaimed mine areas on top of the mountain and some areas of Eastern Hemlock (Tsuga canadensis) and Eastern White Pine (Pinus strobus) mixed with hardwoods (Streets 2001, Vanderhorst 2001). The primary soils on the Pringle TA are loams, silt loams, and rubbly complexes (Bell 2001).

The climate of the Preston County is temperate with moderate winters, relatively warm summers, and equal distribution of precipitation across seasons (Ruffner 1985, Garwood 1996). 
The mean temperature for Preston County is $8.83{ }^{\circ} \mathrm{C}$, and the total annual precipitation is 137.01 cm (Garwood 1996).

\section{METHODS}

\section{Sherman Live Trapping}

Small mammal live trapping grids were established on 25 forested plots on the Cantonment, Pringle, and Briery Mountain properties from 26 June 2000 to 1 September 2000 (Figure 2). Of these 25, 12 were selected for a concurrent coarse woody debris study (Chapter II). The 12 selected grids were each sampled twice more during the 2000 field season from 8 September 2000 to 14 November 2000. Six new grids were established in 2001 from 10 May 2001 to 24 May 2001 for a total of 18 grids (Figure 2). These 18 grids were each trapped during 5 sampling periods in the 2001 field season from 10 May 2001 to 4 December 2001.

Each site was a $60 \times 60 \mathrm{~m}$ grid with 49 trapping stations equally spaced $10 \mathrm{~m}$ apart (Doyle 1990, Laerm et al. 1997, Jorgensen et al. 1998, Loeb 1999). At each station, 1 collapsible $7.7 \times 7.7 \times 23 \mathrm{~cm}$ Sherman aluminum box trap was set within $1 \mathrm{~m}$ of the station center. In addition, at each trapping station 10.946 L plastic pitfall cup was installed to capture mammals not heavy enough to trigger Sherman live traps (Laerm et al. 1997, Jorgensen et al. 1998, Menzel et al. 1999). Grids were trapped for 2 consecutive nights.

Each Sherman trap was baited with about $10 \mathrm{~g}$ ( $1 / 2$ teaspoon) of rolled peanut butter and oats (Beer 1964, Sullivan and Sullivan 1980, Carey and Johnson 1995). Live rodents were eartagged, and live shrews were toe-clipped for related mark-recapture studies (Laerm et al. 1997, Menzel et al. 1999). Species, mass, sex, and reproductive condition were recorded for each animal caught in each trapping method employed (Laerm et al. 1997, Menzel et al. 1999). All dead specimens were collected for later identification and preservation in the West Virginia 
University Vertebrate Collection and Museum Collection at Marshall University. The West Virginia University Animal Care and Use Committee approved the protocols used in this study (00-0405).

\section{Tomahawk Live Trapping}

On 17 of the original 25 grids, $1023 \times 23 \times 48 \mathrm{~cm}$ collapsible Tomahawk cage traps were placed around the exterior of the grid to prevent disturbance of Sherman traps by carnivores. These traps also were set on 28 of the grids during various sessions of trapping in 2001. Tomahawk traps were placed at den and latrine sites of Allegheny Woodrats (Neotoma magister) from 22 September 2000 to 26 September 2000 along a rocky outcrop overlooking the Cheat River on the Pringle Tract (Figure 3).

A Tomahawk live trapping grid was established on the Pringle TA in 2000. During the 2001 field season, 1 Tomahawk grid was sampled on Briery Mountain TA and 2 grids were set on the Cantonment Area (Figure 4). Each Tomahawk grid consisted of 49 cage traps evenly spaced on a $180 \times 180 \mathrm{~m}$ grid. These grids targeted medium-sized mammals too large to be sampled by the smaller Sherman live traps and Victor snap traps. Tomahawk traps were baited with about $20 \mathrm{~g}$ ( 1 teaspoon) of the rolled oat bait (Beer 1964, Sullivan and Sullivan 1980, Carey and Johnson 1995).

\section{Snap Trapping}

Museum Special snap traps were established on 5 sites on the Pringle TA, 3 sites on the Briery Mountain TA, and 3 sites on the Cantonment Area in habitat not covered by the live trapping grids (Figure 4). Each snap trap grid was 2 x 20 with $15 \mathrm{~m}$ spacing (Carey and Johnson 1995). This strip-grid design allowed for the sampling of forest gradients from openings to interior, stream reaches, and open fields. Two traps were placed at each site within $1 \mathrm{~m}$ of the 
marking flag. At each site, 1 randomly chosen trap was baited with rolled peanut butter and oats, and the other trap was baited with rolled peanut butter and cracked corn. Each grid was set for 3 consecutive nights.

\section{Pitfall Trapping}

Small mammals collected from pitfall traps surveying herpetofauna (Spurgeon 2002) were frozen and later analyzed to determine species, mass, sex, and reproductive condition (Burt and Grossenheider 1980) (Figure 5). Pitfall array design was modeled after structures used by Bury and Corn (1987), Mengak and Guynn (1987), and Greenberg et al. (1994) with modified fence lengths, number of fences, and pitfall number and arrangement. Two different types of pitfall arrays were used in this study (Figure 6). The first was a 5-bucket cross-shaped design with a $19 \mathrm{~L}$ bucket in the center and at each end point of the fencing. The second design was a straight fence with 1 bucket on each side of the ends for a total of 4 buckets per array. Each fence for both array types was $7.5 \mathrm{~m}$ of silt fence staked and buried $3-4 \mathrm{~cm}$ in the ground. A small amount of water was placed in the bottom of each bucket to prevent desiccation of amphibians (Spurgeon 2002).

\section{Chiropteran Surveys}

Chiropteran surveys were performed from 1-2 September 2000, 7-9 May 2001, and 12 June 2001 (J. M. Menzel, M. A. Menzel, J. B. Johnson, S. F. Owen, and J. W. Edwards, West Virginia University, unpublished data). Surveys included mist netting, harp trapping, and acoustical monitoring. The Pringle TA and the Cantonment Area were surveyed using mist nets. All 3 tracts of the CDCTA were surveyed using acoustical monitoring equipment. One harp trap was set at the entrance to a mine portal on the top of Pringle Mountain. 
Bats were captured using mist nets placed over streams, ponds, and road ruts. Data recorded from all bats included species, sex, age, reproductive condition, mass, and length of forearm. Age was determined by back-lighting the finger joints and examining the level of epiphyseal-diaphyseal fusion (Anthony 1988). Reproductive condition was determined by palpating the abdomen (Racey 1988). Mass was determined using a Pesola ${ }^{\circledR}$ spring scale.

In addition to mist nets, acoustical surveys of bat communities were conducted on all 3 tracts of the CDCTA. Acoustical monitoring allows distinction among bat species or species groups using search-phase call characteristics as recorded by the Anabat system (Titley Electronics, Australia). Calls of hand-released bats were recorded to establish a call library for each bat species in the study area. Calls were recorded using an Anabat bat detector linked directly to a laptop computer via a Zero Crossing Analysis Interface Module (ZCAIM, Titley Electronics, Australia).

\section{Predator Surveys}

Scent stations baited with fatty-acid tablets were used to assess large carnivore populations during the 2000 and 2001 field seasons. Stations were set $480 \mathrm{~m}$ apart to avoid predator overlap, and specific sites were randomly selected as either a roadside or interior station (Linhart and Knowlton 1975). Roadside stations were set within 5-m from the road while interior stations were set $100 \mathrm{~m}$ from a road. Scent stations consisted of an area $1 \mathrm{~m}$ in diameter cleared of all vegetation and roots, leveled off, and packed down. Sand was sifted onto the area at a depth of 3-5 cm to make tracks more visible (Kalpin 1986). A fatty acid tablet was placed in the center of the circle to act as an attractant to predators (Linhart and Knowlton 1975, Roughton and Sweeney 1982, Kalpin 1986, Nottingham et al 1989, Warrick and Harris 2001). Scent stations were examined for tracks the following day (Traviani et al. 1996, Sargeant et al. 1998, 
Warrick and Harris 2001). Tracks were identified and recorded along with number and direction of tracks. A total of 52 scent stations, 26 roadsides and 26 interiors, were set on the CDCTA. Number of stations per tract of land varied due to size of each tract. The Pringle TA had 21 scent stations, Briery Mountain TA had 18, and the Cantonment Area had 13 stations. Scent stations were operated in August, September, and October 2000 and again in June and July 2001.

\section{Mole Trapping}

Victor Out-of-Sight ${ }^{\circledR}$ (Model 0631) and plunger (Model 0645) (Woodstream Corporation, Lititz, Pennsylvania) traps were used to target mole species on the CDCTA. Outof-Sight ${ }^{\circledR}$ traps were placed in areas that appeared to be mole tunnels, and plunger traps were placed at the opening of tunnels greater than $2 \mathrm{~cm}$ in diameter. In 2000, 3 Out-of-Sight ${ }^{\circledR}$ traps and 2 plunger traps were set on the Volkstone TA from 8 September 2000 to 11 September 2000. The majority of mole trapping was conducted during the 2001 field season. Twelve Out-ofSight $^{\circledR}$ traps and 6 plunger traps were set on the Cantonment Area from 27 March 2001 to 31 March 2001. From 2 July 2001 to 16 July 2001, 6 Out-of-Sight ${ }^{\circledR}$ traps and 3 plunger traps were set on the Briery Mountain TA and the same number of each type were set on the Pringle TA. Due to the lack of captures another round of trapping was attempted. From 6 August 2001 to 20 August 2001, 6 Out-of-Sight ${ }^{\circledR}$ traps and 3 plunger traps were set at new sights on the Briery Mountain TA, and the same number of each trap type set at new spots on the Volkstone TA of the Cantonment Area. Also, from 18 October 2001 to 1 November 2001, 6 Out-of-Sight ${ }^{\circledR}$ traps and 3 plunger traps were set on the Pringle TA and the same number of traps on the Camp Dawson Proper tract of the Cantonment Area. All traps were checked every other day for captures and sprung traps. 


\section{Data Analyses}

Sherman live trap data, snap trap data, and pitfall data were analyzed as catch per unit effort (CPU) with numbers reported as captures per 100 trap nights. This analysis provides abundance measures that can be compared among the different types of trapping (McComb et al. 1991). Corrections were made for sprung and damaged traps in the Sherman live trap and snap trap calculations (Nelson and Clarke 1973). Average CPU values for species representing 10\% of all captures in pitfall traps were compared among tracts and between years. Shannon diversity, Pielou's evenness, and species richness were calculated for pitfall data because pitfalls were spread across all 3 tracts and produced the largest sample sizes for comparison among tracts and between years (Magurran 1988, Krohne 1998). In addition to tract and year, diversity indices were calculated by vegetative community type to describe diversity of small mammals based on vegetative type (Vanderhorst 2001). A Sorenson coefficient of community similarity also was calculated among tracts for pitfall arrays. This coefficient model incorporates the number of species that 2 tracts have in common to produce a percentage of community similarity (Krebs 1999). Sorenson similarity values were also calculated for vegetative communities. This was done by incorporating the number of species in a specific community with the total number of species in all other communities combined. Only number of captures and species captured were reported for Chiropteran mist-netting, tomahawk trapping, and $0.946 \mathrm{~L}$ pitfalls because of low capture success.

Statistical Analysis System (SAS Institute, Cary, North Carolina, USA) was used for all statistical analyses. Analysis of Variance (ANOVA) was used to compare CPU and diversity indices for pitfall data. The independent variables tested in these ANOVA models were year, tract, and year*tract with dependent variables being CPU values and Shannon diversity. 
Assumptions of normality were tested with the univariate procedure in SAS. Bartlett's Test was used for homogeneity of variances. Tukey's Studentized Range Test was used to identify differences among tracts when significant $F$ values $(\alpha=0.05)$ were obtained. The same ANOVA model was used to compare CPU data for Sherman live trap grids and mean number of call sequences for Chiropteran call surveys among tracts. Because each tract was not represented in each year of snap trapping, ANOVA models were run to detect differences in year and tract separately.

\section{RESULTS}

A total of 40 mammalian species was observed on the CDCTA during the study (Table 2): Briery Mountain TA (24 species), Cantonment Area (30), Pringle TA (40). Four of these species are currently listed as rare or threatened by the WVDNR (WVDNR 2000): Long-tailed Shrew, Allegheny Woodrat, Southern Bog Lemming, Meadow Jumping Mouse. No federally threatened or endangered mammalian species were documented on the CDCTA during this survey.

Trapping and active sampling effort produced 6,696 individuals of 30 species on the CDCTA during the 2000 and 2001 field seasons (Appendix Ib). The Briery Mountain TA trapping effort produced 945 individuals of 19 species, Cantonment Area trapping produced 1,905 individuals of 26 species, and trapping on the Pringle TA produced 3,846 individuals of 30 species. Scent station surveys added 6 species to the total number observed, and the other 3 species were observed but not documented in sampling effort.

\section{Sherman Live Trapping}

Sherman traps were set for 4,160 trap nights and provided 348 individuals of 10 different species in 2000. During the 2001 field season, 8,849 trap nights produced 1,216 individuals of 
15 different species. Overall, 1,564 individuals were captured in 13,009 trap nights on the CDCTA using Sherman live traps (Appendix Ib). A year-tract interaction occurred in the ANOVA model of CPU data for Sherman live trapping grids $\left(F_{1,110}=9.83, P=0.002\right)$.

Therefore, a separate ANOVA was run for each year. During the 2000 field season there was no difference between the CPU values for the Pringle TA $(\bar{x}=14.93, \mathrm{SE}=1.13)$ and the Cantonment Area $(\bar{x}=13.04, \mathrm{SE}=1.13)\left(F_{1,34}=1.06, P=0.310\right)$. However, the mean CPU for Sherman grids on the Pringle TA during $2001(\bar{x}=34.96, \mathrm{SE}=1.95)$ was greater than the value for the Cantonment Area $(\bar{x}=23.05, \mathrm{SE}=1.83)\left(F_{1,91}=16.16, P<0.001\right)$.

The most common species captured were White-footed Mouse and Deer Mouse, which were analyzed together as the genus Peromyscus spp. and represented $74 \%$ of all captures. Other common species were Northern Short-tailed Shrew (Blarina brevicauda) (9\%), Southern Redbacked Vole (Clethrionomys gapperi) (4\%), Eastern Chipmunk (Tamias striatus) (3\%), and Southern Flying Squirrel (Glaucomys volans) (1\%) (Table 3). An interaction between year and tract was observed during analysis of CPU values for Peromyscus spp. $\left(F_{1,110}=7.75, P=0.006\right)$. Average CPU values for Peromyscus spp. were similar between the Cantonment Area $(\bar{x}=7.68$, $\mathrm{SE}=0.93)$ and Pringle TA $(\bar{x}=9.86, \mathrm{SE}=1.38)$ during $2000\left(F_{1,34}=1.86, P=0.182\right)$, but the Pringle TA $(\bar{x}=31.34, \mathrm{SE}=2.07)$ showed a higher CPU than the Cantonment Area $(\bar{x}=16.67$, $\mathrm{SE}=1.51)$ in $2001\left(F_{1,76}=23.94, P<0.001\right)$. Both the Pringle TA $\left(F_{1,63}=30.66, P<0.001\right)$ and the Cantonment Area $\left(F_{1,47}=21.85, P<0.001\right)$ showed higher average CPUs in 2001 than 2000 for Peromyscus spp. (Table 3). The Northern Short-tailed Shrew produced higher CPU values in $2001(\bar{x}=2.66, \mathrm{SE}=0.24)$ than $2000(\bar{x}=1.07, \mathrm{SE}=0.21)\left(F_{1,110}=16.16, P<\right.$ 0.001), but abundance was similar between the Pringle TA $(\bar{x}=2.33, \mathrm{SE}=0.29)$ and the 
Cantonment Area $(\bar{x}=1.93, \mathrm{SE}=0.21)\left(F_{1,110}=0.08, P=0.785\right)$. Southern Red-backed Voles were more abundant on the Pringle TA $(\bar{x}=1.67, \mathrm{SE}=0.32)$ than the Cantonment Area $(\bar{x}=$ $0.13, \mathrm{SE}=0.07)\left(F_{1,110}=8.87, P=0.004\right)$ with similar abundance in $2000(\bar{x}=0.29, \mathrm{SE}=0.12)$ and $2001(\bar{x}=1.34, \mathrm{SE}=0.27)\left(F_{1,110}=3.69, P=0.057\right)$. Eastern Chipmunks produced similar CPU values in $2000(\bar{x}=0.41, \mathrm{SE}=0.12)$ and $2001(\bar{x}=0.78, \mathrm{SE}=0.13)\left(F_{1,110}=3.64, P=\right.$ $0.059)$ and on the Pringle TA $(\bar{x}=0.64, \mathrm{SE}=0.14)$ and Cantonment Area $(\bar{x}=0.69, \mathrm{SE}=0.13)$ $\left(F_{1,110}=0.96, P=0.329\right)$. Relative abundance of Southern Flying Squirrels was similar between $2000(\bar{x}=0.31, \mathrm{SE}=0.10)$ and $2001(\bar{x}=0.31, \mathrm{SE}=0.09)\left(F_{1,110}=0.12, P=0.729\right)$ and between the Pringle TA $(\bar{x}=0.40, \mathrm{SE}=0.10)$ and the Cantonment Area $(\bar{x}=0.19, \mathrm{SE}=0.07)$ $\left(F_{1,110}=1.18, P=0.279\right)$. Interactions of tract and year were not significant for Northern Shorttailed Shrews $\left(F_{1,110}=2.11, P=0.149\right)$, Southern Red-backed Voles $\left(F_{1,110}=2.57, P=0.112\right)$, Eastern Chipmunks $\left(F_{1,110}=1.22, P=0.271\right)$, and Southern Flying Squirrels $\left(F_{1,110}=1.68, P=\right.$ $0.198)$.

Rare species captured in Sherman live traps included Allegheny Woodrat and Meadow Jumping Mouse, which are both listed as rare by the WVDNR (WVDNR 2000) (Table 1). Longtailed weasels (Mustela frenata) also were infrequent visitors of Sherman traps. The smaller shrew species like Masked Shrew and Smoky Shrew (Sorex fumeus) were rare in Sherman traps but much more common in pitfall traps.

The small 0.934 L pitfall cups provided 2,300 trap nights in 2000 and 5,334 trap nights in 2001 for a total of 7,634 trap nights overall (Appendix B). Success was low in 2000 with only 12 individuals captured. The capture rate was higher in 2001, but still only 147 individuals were caught for a 2-year total of 159 individuals. Species captured in these pitfalls were the Masked 
Shrew, Smoky Shrew, Northern Short-tail Shrew, Woodland Jumping Mouse, Peromyscus spp., and Southern Red-backed Vole.

\section{Tomahawk Live Trapping}

Tomahawk Livetraps on Sherman grids produced 34 individuals of 6 species in 1,044 potential trap nights during 2000 and 2001: Virginia Opossum $(n=22)$, Eastern Cottontail (Sylvilagus floridanus) $(n=4)$, Raccoon (Procyon lotor) $(n=2)$, Red Squirrel (Tamiasciurus hudsonicus) $(n=2)$, Eastern Fox Squirrel (Sciurus niger) $(n=2)$, and Allegheny Woodrat $(n=$ 2). Woodrat trapping provided 13 individuals in 73 potential trap nights. The squirrel grids on the Pringle TA, Cantonment Area, and Briery Mountain TA provided 618 trap nights and 12 captures of 5 different species: Virginia Opossum $(n=6)$, Red Squirrel $(n=2)$, Long-tailed Weasel ( $n=2)$, Woodchuck (Marmota monax) $(n=1)$, Raccoon $(n=1)$. No species were especially common or rare in tomahawk traps.

\section{Snap Trapping}

Snap trapping provided 960 potential trap nights and 80 captures of 7 mammalian species in 2000. In 2001, snap trapping provided 1,184 potential trap nights and 204 captures of 11 mammalian species. Overall, snap trapping provided 284 individuals of 9 species in 2,144 trap nights. Catch per unit effort values were similar between $2000(\bar{x}=13.57, \mathrm{SE}=4.15)$ and 2001 $(\bar{x}=16.29, \mathrm{SE}=2.79)$ for snap trap data $\left(F_{1,9}=0.32, P=0.588\right)$. For the grids trapped in 2000, the Briery Mountain TA $(\bar{x}=11.43, \mathrm{SE}=5.12)$ showed similar results to the Cantonment Area $(\bar{x}=14.99, \mathrm{SE}=6.79)\left(F_{1,3}=0.14, P=0.734\right)$. In 2001 , there was no difference $\left(F_{1,4}=0.63, P\right.$ $=0.472)$ between the $\mathrm{CPU}$ values for Briery Mountain TA $(\bar{x}=11.15, \mathrm{SE}=0)$ and the Pringle TA $(\bar{x}=17.32, \mathrm{SE}=3.17)$. The most abundant species captured were Peromyscus spp. $(70 \%)$ and Southern Red-backed Voles (8\%). Rare species included Southern Bog Lemming 
(Synaptomys cooperi) and Meadow Jumping Mouse, which are state listed rare species (WVDNR 2000) (Table 1).

\section{Pitfall Trapping}

Herpetofaunal pitfall arrays provided 1,232 individuals of 16 small mammal species in 12,972 trap nights in 2000, and 3,316 individuals of 19 small mammal species in 40,794 trap nights in 2001. Thus, pitfall trapping provided 4,548 individuals of 21 small mammal species in 53,766 trap nights (Appendix Ib). Average CPU values for 2000 and 2001 were similar $\left(F_{1,57}=\right.$ 2.23, $P=0.141)$ (Table 4). All 3 tracts produced similar CPU values $\left(F_{2,57}=1.79, P=0.177\right)$. The interaction between tract and year was close enough to our adopted significance level that CPU was analyzed by year and tract separately $\left(F_{2,57}=3.12, P=0.052\right)$. In 2000 (BM: $\bar{x}=$ 8.79, $\mathrm{SE}=2.92 ; \mathrm{CA}: \bar{x}=16.94, \mathrm{SE}=3.29 ; \mathrm{PT}: \bar{x}=11.24, \mathrm{SE}=2.11)$ and $2001(\mathrm{BM}: \bar{x}=8.25$, $\mathrm{SE}=1.73 ; \mathrm{CA}: \bar{x}=8.40, \mathrm{SE}=1.39 ; \mathrm{PT}: \bar{x}=12.43, \mathrm{SE}=1.47)$ all 3 tracts showed similar $\mathrm{CPU}$ values (2000: $\left.F_{2,20}=2.15, P=0.143 ; 2001: F_{2,37}=2.48, P=0.098\right)$. The Briery Mountain TA $\left(F_{1,13}=0.03, P=0.876\right)$ and Pringle TA $\left(F_{1,27}=0.21, P=0.653\right)$ showed similar CPU values in 2000 and 2001, while the Cantonment Area produced higher relative abundance of small mammals in 2000 than $2001\left(F_{1,17}=7.02, P=0.017\right)$.

The 5 most abundant species captured were Masked Shrew ( $n=1502,33 \%)$, Peromyscus spp. $(n=773,17 \%)$, Smoky Shrew $(n=537,11 \%)$, Northern Short-tailed Shrew $(n=504$, $11 \%)$, and Woodland Jumping Mouse $(n=473,10 \%)$. Relative abundance of Masked Shrew was similar among tracts $\left(F_{2,57}=3.00, P=0.058\right)$ and years $\left(F_{1,57}=1.51, P=0.225\right)$ (Table 4$)$. Peromyscus spp. were captured more frequently on Pringle than Briery Mountain and the Cantonment Area $\left(F_{2,57}=6.03, P=0.004\right)$. No difference was observed between the Briery Mountain and Cantonment Area CPU values for Peromyscus spp. Abundance of Peromyscus 
spp. was similar between years $\left(F_{1,57}=0.18, P=0.676\right)$. Average CPU for the Smoky Shrew was higher in 2001 than $2000\left(F_{1,57}=14.59, P<0.001\right)$ and similar among tracts $\left(F_{2,57}=1.14\right.$, $P=0.327)$. The Woodland Jumping Mouse was more abundant on Pringle and the Cantonment Area than Briery Mountain, but Cantonment and Pringle values were similar $\left(F_{2,57}=9.97, P<\right.$ 0.001). Abundance of Woodland Jumping Mice was similar between years $\left(F_{1,57}=0.70, P=\right.$ 0.405). Northern Short-tailed Shrews produced higher CPU estimates in 2001 than $2000\left(F_{1,57}=\right.$ 11.29, $P=0.001)$ with similar abundance among tracts $\left(F_{2,57}=2.32, P=0.107\right)$. Interactions of tract and year were not significant for Masked Shrews $\left(F_{2,57}=0.14, P=0.870\right)$, Peromyscus spp. $\left(F_{2,57}=1.30, P=0.279\right)$, Smoky Shrews $\left(F_{2,57}=0.58, P=0.566\right)$, Woodland Jumping Mice $\left(F_{2}\right.$, $\left.{ }_{57}=0.93, P=0.401\right)$, or Northern Short-tailed Shrews $\left(F_{2,57}=0.47, P=0.625\right)$.

Species captured infrequently in pitfall traps included Pygmy Shrew (Sorex hoyi), Hairytailed Mole (Parascalops breweri), Least Weasel (Mustela rixosa), Southern Flying Squirrel (Glaucomys volans), and Eastern Cottontail (Table 4). The Long-tailed Shrew (Sorex dispar), Southern Bog Lemming, and Meadow Jumping Mouse are species from the WVDNR state rare species list that were captured in pitfall traps on the CDCTA (Table 1).

Mean Shannon diversity $\left(F_{1,57}=3.16, P=0.081\right)$ and Pielou evenness $\left(F_{1,57}=1.50, P=\right.$ $0.226)$ were similar in 2000 and 2001 (Table 4). Diversity $\left(F_{2,57}=3.88, P=0.026\right)$ and evenness $\left(F_{2,57}=3.33, P=0.043\right)$ were higher on the Pringle TA than the Briery Mountain TA with no difference in diversity or evenness between the Pringle TA and the Cantonment Area or between the Briery Mountain TA and the Cantonment Area. Species richness was higher in 2000 than $2001\left(F_{1,57}=8.39, P=0.005\right)$, but no difference in species richness was observed among tracts $\left(F_{2,57}=0.75, P=0.479\right)$. No interaction was observed between tract and year in 
diversity $\left(F_{2,57}=0.49, P=0.618\right)$, evenness $\left(F_{2,57}=0.44, P=0.644\right)$, or richness $\left(F_{2,57}=0.05, P\right.$ $=0.953)$.

Shannon diversity indices were different between vegetative communities $\left(F_{11,50}=4.68\right.$, $P<0.001$ ) (Figure 7). The highest indices were observed in developed areas and Hemlock ravines while the lowest Shannon indices were observed on former agricultural lands (Table 5). Pielou's evenness index also was different between vegetative communities $\left(F_{11,50}=3.99, P<\right.$ 0.001) with developed area and mixed mesophytic forests of colluvial slopes producing the highest evenness values and sub-xeric Oak forests producing the lowest evenness indices. Species richness was similar across vegetative community types $\left(F_{11,50}=1.61, P=0.124\right)$. The highest Sorenson similarity values were observed in mixed mesophytic forests of colluvial slopes (93\%), successional forests of low elevation plains (88\%), and old fields (88\%). The lowest Sorenson values were observed in former agricultural land (54\%), disturbed areas (59\%), and roads $(59 \%)$.

Sorensen community similarity values for the 2000 trapping season showed $93 \%$ similarity between Pringle TA and Briery Mountain TA, $86 \%$ similarity between Pringle TA and the Cantonment Area, and 93\% similarity between Briery Mountain TA and the Cantonment Area. In 2001, the Sorenson coefficient between Pringle TA and Briery Mountain TA decreased slightly to $91 \%$, while the similarity between Pringle TA and the Cantonment Area increased to 94\%. The similarity coefficient between Briery Mountain TA and the Cantonment Area decreased slightly to $91 \%$. Overall Sorenson indices were $92 \%$ for Pringle and Briery, $90 \%$ for Pringle and Cantonment, and 92\% for Briery Mountain and the Cantonment Area. 


\section{Chiropteran Surveys}

Bats were surveyed at 27 mist-net nights at 8 survey areas during fall 2000 and summer 2001. Overall, 21 individuals of 5 species were captured: Big Brown Bat (Eptesicus fuscus) ( $n$ $=2$ ), Eastern Red Bat (Lasiurus borealis) $(n=1)$, Little Brown Bat (Myotis lucifugus) $(n=2)$, Northern Long-eared Myotis (Myotis septentrionalis) $(n=8)$, and Eastern Pipistrelle (Pipistrellus subflavus) $(n=8)$.

A total of 638 call sequences was recorded in 21 detector-nights during fall 2000 and summer 2001 on the CDCTA. Six bat species were recorded: Eastern Pipistrelle ( $n=120$ call sequences), Big Brown Bat $(n=143)$, Little Brown Bat $(n=181)$, Northern Long-eared Myotis ( $n=16)$, Eastern Red Bat ( $n=27)$, and Hoary Bat (Lasiurus cinereus) $(n=39)$. All species produced similar numbers of calls among the 3 tracts of land (Table 6). An additional 13 sequences were emitted by myotids, but could not be classified to species. A total of 86 call sequences were not identifiable and were placed into the non-identifiable category.

\section{Predator Surveys}

A total of 15 identifiable species were recorded at predator scent stations on the CDCTA (Table 7). Bobcat (Felis rufus) and Coyote (Canis latrans) were rare visitors of scent stations. Raccoons and Virginia Opossums were abundant on all tracts of the CDCTA. Black Bear (Ursus americanus) tracks were found regularly on the Pringle Tract and were recorded on Pringle and Briery Mountain scent stations. Striped Skunk (Mephitis mephitis) was identified on the Pringle TA during the July 2001 sampling period. 


\section{Mole Trapping}

No captures were recorded in 869 trap nights with Out-of-Sight ${ }^{\circledR}$ and plunger mole traps on the CDCTA. Though mole trapping did not produce any results, 10 Starnose Moles (Condylura cristata) and 4 Hairy-tailed Moles were collected during pitfall trapping in 2001.

\section{DISCUSSION}

Of the 59 species whose range maps overlap the study site, $40(68 \%)$ were observed on the CDCTA during 2000 and 2001 (Burt and Grossenheider 1980, Merritt 1987, Wilson and Reeder 1993). Trapping and active sampling effort produced 30 (51\%) species, and 10 species (17\%) were recorded through visual observation or sign. Thus, 19 species with range maps overlapping the study site were not observed in this study (Appendix Ia).

House Mouse (Mus musculus) and Norway Rat (Rattus norvegicus) are common rodents throughout the United States, but neither species was observed on the CDCTA during the course of this study. However, no sampling was conducted in the immediate vicinity of the main office buildings on the Cantonment Area. House Mice and Norway Rats are typically found in and around dwellings inhabited by humans (Burt and Grossenheider 1980, Merritt 1987). Red Fox (Vulpes vulpes) and Gray Fox (Urocyon cinereoargenteus) are relatively common carnivores that were not detected in scent station surveys on the CDCTA (Merritt 1987). Surprisingly, Coyotes were detected, but Red and Gray Foxes did not visit scent stations. The Muskrat (Ondatra zibethicus) is another common species that was not observed on the study site. The CDCTA lacks an extensive wetland system, but there are several wetland patches and ponds that would provide adequate habitat for a generalist wetland species like the Muskrat (Merritt 1987). Presence of American Beaver (Castor canadensis) was confirmed through observation of the species as well as lodges, gnawed tree trunks, and slides of matted vegetation around wetlands. 
These are the same general signs used to detect Muskrats, so there is the possibility that some sign was mistakenly identified. River Otters (Lontra canadensis) were not recorded and probably do not exist on the study area due to low water quality from acid mine drainage and the associated lack of fish in the streams on the CDCTA.

Six species from the WV rare species list that have ranges overlapping the study site were not detected on the CDCTA (Appendix Ia). The Chiropteran surveys conducted in this study were not extensive, and 4 of these 6 species are uncommon bats rarely noted in this region of the country (M. A. Menzel, West Virginia University, personal communication). Any future monitoring should include more exhaustive surveys of the chiropteran communities of the CDCTA to determine if any of these uncommon species occurs on the property. The other rare species not captured are the Least Shrew (Cryptotis parva) and the Eastern Spotted Skunk (Spilogale putorius). The Least Shrew is generally an inhabitant of open, early successional habitat types like old fields and abandoned pastures (Whitaker 1974, Burt and Grossenheider 1980, Merritt 1987). Patches of open grassland and old-field habitat are present on all 3 tracts of the CDCTA (Vanderhorst 2001). Whitaker (1974) notes the difficulty in trapping this species with conventional methods, and our lack of captures could simply be due to this difficulty. The Eastern Spotted Skunk is patchily distributed throughout its range and occurs in brushy or densely wooded habitats (Merritt 1987, Kinlaw 1995). The inability to capture this species could be attributed to its localized distribution or the lack of Tomahawk trapping effort in dense, brushy habitat types.

The 4 state listed rare species that were trapped on the CDCTA provide an interesting opportunity for further study of local populations of these species (WVDNR 2000). Buffer zones based on estimated home range size of each state rare species were created around 
locations where each species was recorded (Figure 8). For the Allegheny Woodrat, Meadow Jumping Mouse, and Long-tailed Shrew a buffer zone of $100 \mathrm{~m}$ was used (Whitaker 1972, Burt and Grossenheider 1980, Wiley 1980, Kirkland 1981, Merritt 1983). A buffer zone of $50 \mathrm{~m}$ was used for the Southern Bog Lemming (Burt and Grossenheider 1980, Linzey 1983, Merritt 1987).

There appears to be a healthy population of Allegheny Woodrats along the steep, rocky slope of interior hardwood forest on the south end of the Pringle TA. The mature mast trees in this area provide a valuable food base for the woodrats, and the large rocky outcroppings provide shelter and protection (Wiley 1980). Habitat characteristics that affect woodrat numbers include percent rock cover and aspect (Balcom and Yahner 1996). Human caused disturbance like forest fragmentation do not directly decrease numbers of woodrats (Balcom and Yahner 1996). However, any timbering activities that occur in or near areas where woodrats reside should take into account the need to provide a reasonable amount of forest cover around large, rocky southfacing slopes for the maintenance of woodrat populations on the CDCTA (Wiley 1980). In addition, consistent monitoring of woodrat populations will provide valuable information on local population status and health.

In this region of the country, Southern Bog Lemmings are found in a variety of habitats, but they are most commonly found in wet meadows on reclaimed mines (Linzey 1983, Merritt 1987). The riparian habitat along the Cheat River and its tributaries is important habitat for Southern Bog Lemmings on the CDCTA (Linzey 1983). These habitat types are most prevalent on the Cantonment Area and the Pringle TA (Vanderhorst 2001). However, Southern Bog Lemmings were occasional or common on all 3 tracts of the CDCTA (Table 2).

Meadow Jumping Mice are rare in West Virginia because of a statewide lack of suitable habitat for the species. However, compared to other parts of the state, the CDCTA provides a 
large amount of habitat for this species. The number of Meadow Jumping Mice captured in this study, especially on the Cantonment Area and reclaimed mine sections of the Pringle TA, is a testament to this fact (Appendix B). Grassy fields and wet meadows are ideal habitat for Meadow Jumping Mice (Whitaker 1972, Burt and Grossenheider 1980, Merritt 1987). Therefore, these grassland patches should be maintained and enhanced to provide cover and forage for Meadow Jumping Mice and Southern Bog Lemmings (Anderson et al. 2002). Because grassland habitat is scarce throughout the state of West Virginia, it is important to preserve the patches that do exist. Monitoring populations will provide better evidence of any specific requirements or activities that might promote better quality habitat for Meadow Jumping Mice or any other small mammal species.

Little is known about the life history and ecology of the Long-tailed (rock) Shrew (Merritt 1987). The species was occasionally collected on the CDCTA. Long-tailed Shrews are generally found in moist, rocky areas of deciduous or mixed deciduous-conifer forest and along cool mountain streams (Kirkland 1981). These are generally the same habitat characteristics as other shrew species that occur on the CDCTA (Burt and Grossenheider 1980, Merritt 1987). Management of habitat specifically for Long-tailed Shrews is virtually impossible given the lack of information on life history characteristics and habitat requirements of the species (Kirkland 1981). Maintenance of wooded, rocky slopes is the best management strategy for protecting most of the shrew species that occur on the CDCTA. Given the remoteness and inaccessibility of steep rocky slopes on the CDCTA properties, a hands-off management scheme might be the best option for protecting small mammal habitat. Of course, consistent monitoring of rare species is crucial for managers to recognize problems and concerns before they reach 
catastrophic levels. All rare species on the CDCTA property should be monitored at least every few years to avoid the loss of species due to anthropogenic factors.

Sherman live trapping produced a variety of small mammal species including Long-tailed Weasels, Red Squirrels, and Virginia Opossums that are not targeted by this trapping method and uncommon in Sherman traps due to the size of these animals. Peromyscus spp. are the most common wild rodents across the United States (Burt and Grossenheider 1980, Merritt 1987), and it was no surprise that White-footed Mice and Deer Mice comprised 74\% of all Sherman live trap captures (Merritt 1987, Loeb 1999). Average CPU for Sherman live trapping grids were much greater in 2001 than the 2000. Small mammal populations frequently fluctuate in cycles due to various habitat and climatic factors (Cary and Johnson 1995, Krohne 1998). These data show that managers must be wary of data collected in a single year on small mammals and population estimates calculated from those data. Managers should create a sampling design that incorporates multiple years of trapping to account for population cycles and stochastic events that can affect population estimates. Though snap trap grids were set in areas not sampled by Sherman grids, Southern Bog Lemming was the only species sampled in snap trap grids that was absent from Sherman trapping.

Overall, pitfall trapping provided the best information on the small mammal communities of the CDCTA. Pitfalls provided the highest number of overall captures and highest number of different small mammal species. These results are consistent with studies comparing capture success of different trapping methods (Williams and Braun 1983, McComb et al. 1991). Though not statistically tested in this study, CPU values for pitfall trapping were lower than those produced by live trapping and snap trapping. Species composition of capture results also was different. Larger rodents like Peromyscus spp., voles, and chipmunks were more likely to be 
captured in live traps and snap traps, while small shrew species were most abundant in pitfall traps (McComb et al. 1991). However, the drawback of pitfall trapping is the high mortality rate. These results suggest a combination of trapping methods is the best way to sample the entire community of small mammal species on the CDCTA.

Shannon diversity indices for small mammal species trapped in pitfall arrays were similar between years, so there appears to be no reduction in diversity associated with pitfall trapping. Shannon diversity was significantly higher on the Pringle TA than the Briery Mountain TA, with no difference detected between Pringle and Cantonment values or Cantonment and Briery Mountain values. The higher diversity on the Pringle TA is most likely due to the greater variety of habitat types on the Pringle TA (Vanderhorst 2001). Briery Mountain is a relatively homogeneous landscape of recently logged, young forest with several small open areas. The Pringle TA provides areas of young forest, mature forest, open mine land, scrub-shrub grassland, conifer forest, riparian habitat, and several small wetlands (Vanderhorst 2001). The analysis of Shannon diversity by vegetative community type also produced higher diversity indices on the Pringle TA and the Cantonment Area than the Briery Mountain TA. One factor contributing to the lower indices in the sub-xeric Oak forest, agricultural land, and disturbed areas could be the low number of pitfall arrays located in these areas. However, several other community types contained 1 or 2 pitfall arrays and produced higher Shannon diversity values.

All bats captured and recorded by Anabat detectors on the CDCTA are common in West Virginia and were expected to be present at Camp Dawson. Moreover, on the basis of range and ecology, it is possible that Silver-haired Bats (Lasioncyteris noctivagans) occur at Camp Dawson during migration in spring and fall. Although Indiana Bats are reported in West Virginia during the winter (Stihler 1992), they rarely occur in West Virginia during the summer (Owen et al. 
2001). Camp Dawson does not occur in the typical range of the Indiana Bat, so it is unlikely, but not impossible, that Indiana Bats occur on the site.

All species sampled by predator scent stations are relatively common in West Virginia and the eastern United States (Burt and Grossenheider 1980, Merritt 1987). The Long-tailed Weasel and Striped Skunk were unexpected visitors because Mustelids are uncommon visitors of predator scent stations (Roughton and Sweeney 1982). Future scent station monitoring should continue to include interior and edge stations to fully assess local carnivore populations.

Mole trapping was unsuccessful on the CDCTA. The Victor mole traps used in this study are generally for Eastern Moles (Scalopus aquaticus) and western mole species, which are larger than the 2 species documented on the CDCTA. These traps are most effective when used in areas where moles are nuisance species and mole tunnels and entrances are obvious. Searching for mole species and setting traps to target secretive species like the Starnose Mole was not effective because of the difficulty in locating underground tunnels. During future monitoring at the CDCTA, it is recommended that pitfall trapping during the spring and fall be used to target mole species. 


\section{LITERATURE CITED}

Anderson, J. T., G. M. Forcey, J. D. Osbourne, and A. B. Spurgeon. 2002. Wildlife management plan for the Camp Dawson Collective Training Area, Kingwood, West Virginia. Division of Forestry, West Virginia University, Morgantown, West Virginia, USA.

Anthony, E. L. P. 1988. Age determination. Pages 47-57 in T. H. Kunz, editor. Ecological and behavioral methods for the study of bats. Smithsonian Institution Press, Washington, D.C., USA.

Balcom, B. J., and R. H. Yahner. 1996. Microhabitat and landscape characteristics associated with the threatened Allegheny woodrat. Conservation Biology 10:515-525.

Beer, J. R. 1964. Bait preferences of some small mammals. Journal of Mammalogy 45:632-634.

Bell, J.W. 2001. Soil survey of Camp Dawson, Preston County, West Virginia. U.S. D.A. Natural Resources Conservation Service.

Burt, W. H., and R. P. Grossenheider. 1980. A field guide to mammals of North America to Mexico: Third Edition. the Peterson Field Guide Series. Houghton Mifflin, New York, USA.

Bury, R. B., and P. S. Corn. 1987. Evaluation of pitfall trapping in northwestern forests: trap arrays with drift fences. Journal of Wildlife Management 51:112-119.

Butts, S. R., and W. M. McComb. 2000. Associations of forest floor vertebrates with coarse woody debris in managed forests of western Oregon. Journal of Wildlife Management 64:95-104. 
Carey, A. B., and M. L. Johnson. 1995. Small mammals in managed, naturally young, and oldgrowth forests. Ecological Applications 5:336-352.

Chew, R. M. 1976. The impact of small mammals on ecosystem structure and function. Pages 167-180 in D. P. Snyder, editor. Populations of small mammals under natural conditions: a symposium held on May 14-16. Pymatuning Laboratory of Ecology Special Publication Series Volume 5.

Doyle, A. T. 1990. Use of riparian and upland habitats by small mammals. Journal of Mammalogy 71:14-23.

Elliot, P. F. 1974. Evolution of responses of plants to seed eaters: pine squirrel predation on lodgepole pine. Evolution 28:221-231.

Fedriani, J. M., T. K. Fuller, R. M. Sauvajot, and E. C. York. 2000. Competition and intraguild predation among three sympatric carnivores. Oecologia 125:258-270.

French, N. R., W. E. Grant, W. Grodzinski, and D. M. Swift. 1976. Small mammal energetics in grassland ecosystems. Ecological Monographs 46:201-220.

Garwood, A. N., editor. 1996. Weather America: The latest detailed climatological data for over 4,000 places with rankings. Toucan Valley Publications, Milpitas, California, USA.

Greenberg, C. H., D. G. Neary, and L. D. Harris. 1994. A comparison of herpetofaunal sampling effectiveness of pitfall, single-ended, and double-ended funnel traps used with drift fences. Journal of Herpetology 28:319-324.

Jorgensen, E. E., S. Demarais, S. M. Sell, and S. P. Lerich. 1998. Modeling habitat suitability for small mammals in Chihuahuan desert foothills of New Mexico. Journal of Wildlife Management 62:989-996. 
Kalpin, M. C. 1986. Scent station indices as a measure of fox abundance. Thesis, West Virginia University, Morgantown, West Virginia, USA.

Kinlaw, A. 1995. Spilogale putorius. Mammalian Species 511:1-7.

Kirkland, G.L., Jr. 1981. Sorex dispar and Sorex gaspensis. Mammalian Species 155:1-4.

Krebs, C. J. 1999. Ecological methodology. Second edition. Addison Wesley Longman, Menlo Park, California, USA.

Krohne, D. T. 1998. General ecology. Wadsworth, Belmont, California, USA.

Laerm, J., M. A. Menzel, D. J. Wolf, and J. R. Welch. 1997. The effect of riparian zones in structuring small mammal communities in the southern Appalachians. Pages 132-145 in J. E. Cook and B. P. Oswald, compilers. Proceedings of the First Biennial North American Forest Ecology Workshop. Society of American Foresters, North Carolina State University, Raleigh, North Carolina, USA.

Lekunze, L. M., A. U. Ezealor, and T. O. Aken. 2001. Prey groups in the pellets of the barn owl (Tyto alba) in the Nigerian savanna. African Journal of Ecology 39:38-44.

Liebhold, A., J. Elkinton, P. Williams, and R. M. Muzika. 2000. What causes outbreaks of the gypsy moth in North America? Population Ecology 42:257-266.

Linhart, S. B., and F. F. Knowlton. 1975. Determining the relative abundance of coyotes by scent station lines. Wildlife Society Bulletin 3:119-124.

Linzey, A.V. 1983. Synaptomys cooperi. Mammalian Species 210:1-5.

Loeb, S. C. 1999. Responses of small mammals to coarse woody debris in a southeastern pine forest. Journal of Mammalogy 80:460-471.

Magurran, A. E. 1988. Ecological diversity and its measurement. Princeton University Press, Princeton, New Jersey, USA. 
McComb, W. C., R. G. Anthony, and K. McGarigal. 1991. Differential vulnerability of small mammals and amphibians to two trap types and two trap baits in Pacific Northwest Forests. Northwest Science 65:109-115.

Mengak, M. T., and D. C. Guynn. 1987. Pitfalls and snap traps for sampling small mammals and herpetofauna. American Midland Naturalist 118:284-288.

Menzel, M. A., W. M. Ford, J. Laerm, and D. Krishon. 1999. Forest to wildlife openings: habitat gradient analysis among small mammals in the southern Appalachians. Forest Ecology and Management 114:227-232.

Merritt, J. F. 1987. Mammals of Pennsylvania. University of Pittsburgh Press, Pittsburgh, Pennsylvania, USA.

Midwest Research Institute (MRI). 1994. Environmental assessment of the Volkstone property Preston County, West Virginia. MRI Contract F33615-89-D-4004.

Molsher, R. L., E. J. Gifford, and J. C. Mcllroy. 2000. Temporal, spatial, and individual variation in the diet of red foxes (Vulpes vulpes) in central New Southern Wales. Wildlife Research 27:593-601.

Nelson, L., Jr., and F. W. Clark. 1973. Correction for sprung traps in catch/effort calculations of trapping results. Journal of Mammalogy 54:295-298.

Nottingham, B. G., Jr., K. G. Johnson, and M. R. Pelton. 1989. Evaluation of scent-station surveys to monitor raccoon density. Wildlife Society Bulletin 17:29-35.

Owen, S. F., M. A. Menzel, W. M. Ford, B. R. Chapman, K. V. Miller, J. W. Edwards and P. B. Wood. 2001. First summer record of female Indiana myotis, Myotis sodalis, in West Virginia. Journal of the Elisha Mitchell Scientific Society 117:132-134.

Platt, W. J., and N. R. Blakely. 1973. Short-term effects of shrew predation on invertebrate prey sets in prairie ecosystems. Proceedings of the Iowa Academy of Science 80:60-66. 
Racey, P. A. 1988. Reproductive assessment in bats. Pages 31-45 in T. H. Kunz, editor. Ecological and behavioral methods for the study of bats. Smithsonian Institution Press, Washington, D.C. pp. 31-45.

Roughton, R. D., and M. W. Sweeney. 1982. Refinements in scent-station surveys. Journal of Wildlife Management 46:217-229.

Ruffner, J. A. 1985. Climates of the states: National Oceanic and Atmospheric Administration narrative summaries, tables, and maps for each state with overview of state climatologist programs. Volume 2. National Oceanic and Atmospheric Administration, Gale Research Company, Washington, D. C., USA.

Ryszkowski, L., J. Goszczynski, and J. Truszkowski. 1973. Trophic relationships of the common vole in cultivated fields. Acta Theriologica 18:125-165.

Sargeant, G. A., D. H. Johnson, and W. E. Berg. 1998. Interpreting carnivore scent-station surveys. Journal of Wildlife Management 62:1235-1245.

Spurgeon, A. B. 2002. Comparison of herpetofaunal species' composition and response to edge on the Camp Dawson Collective Training Area, Preston County, West Virginia. Thesis, West Virginia University, Morgantown, West Virginia, USA.

Stihler, C. W. and V. Brack, Jr. 1992. A survey of hibernating bats in Hellhole Cave, Pendleton County, West Virginia. Proceedings of the West Virginia Academy of Science. 64:97103.

Streets, B. P. 2001. Floristic inventory of the Camp Dawson Army Training Site, Preston County, West Virginia. Nongame Wildlife and Natural Heritage Program, Wildlife Resources Section, Division of Natural Resources, Elkins, West Virginia. Prepared for the West Virginia Army National Guard. 
Sullivan, D. S., and T. P. Sullivan. 1980. Deer mouse trappability in relation to bait preference. Canadian Journal of Zoology 58:2282-2284.

Traviani, A. R., R. Laffilte, and M. Delibes. 1996. Determining the relative abundance of European red foxes by scent-station methodology. Wildlife Society Bulletin 24:500-504.

U. S. Army Center for Health Promotion and Preventive Medicine (USACHPPM). 1994.

Site assessment survey of Camp Dawson and other selected sites of the West

Virginia Army National Guard, West Virginia. Number 38-26-2459-95.

Vanderhorst, J. 2001. Plant community classification and mapping of Camp Dawson Collective Training Area, Preston County, West Virginia. Nongame Wildlife and Natural Heritage Program, Wildlife Resources Section, Division of Natural Resources, Elkins, West Virginia.

Warrick, G. D., and C. E. Harris. 2001. Evaluation of spotlight and scent-station surveys to monitor kit fox abundance. Wildlife Society Bulletin 29:827-832.

West Virginia Army Reserve National Guard (WVARNG). 2001. Integrated Natural Resources Management Plan. Camp Dawson, Preston County, West Virginia, USA.

West Virginia Division of Natural Resources (WVDNR). 2000. Rare Species List: Vertebrates.

Whitaker, J. O., Jr. 1972. Zapus hudsonius. Mammalian Species 11:1-7.

Whitaker, J. O., Jr. 1974. Cryptotis parva. Mammalian Species 43:1-8.

Whitaker, J. O., Jr. 1996. National Audubon Society Field Guide to North American Mammals. Alfred A. Knopf, New York, New York, USA, and Chanticleer Press, New York, New York, USA.

Wiley, R.W. 1980. Neotoma floridana. Mammalian Species 139:1-7. 
Williams, D. F., and S. E. Braun. 1983. Comparison of pitfall and conventional traps for sampling small mammal populations. Journal of Wildlife Management 47:841-845.

Wilson, D. E., and D. M. Reeder, editors. 1993. Mammal Species of the World. Smithsonian Institution Press, Washington, D. C., USA. 
Table 1. Mammalian species listed on the West Virginia Rare Species List with global and state rank (WVDNR 2000). Species in bold were documented on the Camp Dawson Collective Training Area in Preston County, West Virginia during 2000 and 2001.

\begin{tabular}{|c|c|c|c|c|}
\hline Family & Common Name & Genus Species & $\begin{array}{l}\text { Global } \\
\text { Rank }^{\mathrm{a}}\end{array}$ & $\begin{array}{l}\text { State } \\
\text { Rank }^{\mathrm{b}}\end{array}$ \\
\hline Soricidae & Southern Water Shrew & Sorex palustris punctatum & G5TE & $\mathrm{S} 1$ \\
\hline Soricidae & Long-tailed Shrew & Sorex dispar & G4 & S2, S3 \\
\hline Soricidae & Southern Pygmy Shrew & Sorex hoyi winnemana & G5T4 & $\mathrm{S} 2 \mathrm{~S} 3$ \\
\hline Soricidae & Least shrew & Cryptotis parva & G5 & $\mathrm{S} 2$ \\
\hline Vespertilionidae & Eastern Big-eared Bat & Corynorhinus rafinesquii & G3G4 & $\mathrm{S} 1$ \\
\hline Vespertilionidae & Virginia Big-eared Bat & $\begin{array}{l}\text { Corynorhinus townsendii } \\
\text { virginianus }\end{array}$ & G4T2 & $\mathrm{S} 2$ \\
\hline Vespertilionidae & Silver-haired Bat & Lasionycteris noctivagans & G5 & $\mathrm{S} 2$ \\
\hline Vespertilionidae & Gray Bat & Myotis grisescens & G3 & SA \\
\hline Vespertilionidae & Eastern Small-footed Bat & Myotis leibii & G3 & $\mathrm{S} 1$ \\
\hline Vespertilionidae & Indiana Bat & Myotis sodalis & $\mathrm{G} 2$ & S1 \\
\hline Vespertilionidae & Evening Bat & Nycticeius humeralis & G5 & $\mathrm{SH}$ \\
\hline Leporidae & Appalachian Cottontail & Sylvilagus obscurus & G4 & S3 \\
\hline Sciuridae & $\begin{array}{l}\text { Virginia Northern Flying } \\
\text { Squirrel }\end{array}$ & $\begin{array}{l}\text { Glaucomys sabrinus } \\
\text { fuscus }\end{array}$ & G5T2 & $\mathrm{S} 2$ \\
\hline Muridae & Golden Mouse & Ochrotomys nuttalli & G5 & $\mathrm{S} 2$ \\
\hline Muridae & Eastern Harvest Mouse & Reithrodontomys humulis & G5 & S1 \\
\hline Muridae & Allegheny Woodrat & Neotoma magister & G3G4 & S3 \\
\hline Muridae & Prairie Vole & Microtus ochrogaster & G5 & $\mathrm{S} 3$ \\
\hline
\end{tabular}


Table 1. Continued.

\begin{tabular}{llllc}
\hline \multicolumn{1}{c}{ Family } & \multicolumn{1}{c}{ Common Name } & Genus Species & $\begin{array}{c}\text { Global } \\
\text { Rank }^{\mathrm{a}}\end{array}$ & $\begin{array}{c}\text { State } \\
\text { Rank }^{\mathrm{b}}\end{array}$ \\
\hline Muridae & Southern Rock Vole & Microtus chrotorrhinus & G4T3 & S2 \\
carolinensis & & G5 & S2 \\
Muridae & Southern Bog Lemming & Synaptomys cooperi & G5 & S3 \\
Dipodidae & Meadow Jumping Mouse & Zapus hudsonius & G5 & S2S3 \\
\hline
\end{tabular}

${ }^{\mathrm{a}} \mathrm{G} 1=0-5$ documented globally (DG), G2 = 6-20 DG, G3 = 21-100 DG, G4 = common globally, G5 $=$ very common globally, $\mathrm{T} \#=$ subspecies rank

${ }^{\mathrm{b}} \mathrm{S} 1=0-5$ documented statewide (DS), S2 = 6-20 DS, S3 = 21-100 DS, SA = accidental, $\mathrm{SH}=$ historical 
Table 2. Relative abundance of mammalian species observed on the Camp Dawson Collective Training Area (CDCTA) in Preston County, West Virginia during 2000 and 2001. Species with an * were captured on the CDCTA, and relative abundance for these species was calculated using number of individuals captured. For species observed but not captured relative abundance was based on frequency of observation.

\begin{tabular}{|c|c|c|c|c|}
\hline \multirow[b]{2}{*}{ Common Name } & \multirow[b]{2}{*}{ Scientific Name } & \multicolumn{3}{|c|}{ Relative Abundance $^{a b}$} \\
\hline & & $\mathrm{BM}$ & $\mathrm{CA}$ & PT \\
\hline *Virginia Opossum & Didelphis virginiana & $\mathrm{R}$ & $\mathrm{O}$ & $\mathrm{O}$ \\
\hline *Masked Shrew & Sorex cinereus & A & A & A \\
\hline *Smoky Shrew & Sorex fumeus & $\mathrm{C}$ & A & A \\
\hline *Long-tailed Shrew & Sorex dispar & $\mathrm{O}$ & $\mathrm{R}$ & $\mathrm{O}$ \\
\hline *Pygmy Shrew & Sorex hoyi & $\mathrm{R}$ & $\mathrm{R}$ & $\mathrm{R}$ \\
\hline *Northern Short-tailed Shrew & Blarina brevicauda & $\mathrm{C}$ & A & A \\
\hline *Starnose Mole & Condylura cristata & $\mathrm{R}$ & $\mathrm{R}$ & $\mathrm{R}$ \\
\hline *Hairytail Mole & Parascalops breweri & & $\mathrm{R}$ & $\mathrm{R}$ \\
\hline *Little Brown Bat & Myotis lucifugus & & & $\mathrm{R}$ \\
\hline *Northern Long-eared Myotis & Myotis septentrionalis & & $\mathrm{R}$ & $\mathrm{R}$ \\
\hline *Eastern Pipistrelle & Pipistrellus subflavus & & & $\mathrm{R}$ \\
\hline *Big Brown Bat & Eptesicus fuscus & & $\mathrm{R}$ & $\mathrm{R}$ \\
\hline Eastern Red Bat & Lasiurus borealis & & & $\mathrm{R}$ \\
\hline Hoary Bat & Lasiurus cinereus & & $\mathrm{R}$ & $\mathrm{R}$ \\
\hline
\end{tabular}


Table 2. Continued.

\begin{tabular}{|c|c|c|c|c|}
\hline \multirow[b]{2}{*}{ Common Name } & \multirow[b]{2}{*}{ Scientific Name } & \multicolumn{3}{|c|}{ Relative Abundance $^{\mathrm{ab}}$} \\
\hline & & $\mathrm{BM}$ & $\mathrm{CA}$ & PT \\
\hline *Eastern Cottontail & Sylvilagus floridanus & & $\mathrm{R}$ & $\mathrm{R}$ \\
\hline American Beaver & Castor Canadensis & & & $\mathrm{O}$ \\
\hline Woodchuck & Marmota monax & $\mathrm{O}$ & $\mathrm{R}$ & $\mathrm{O}$ \\
\hline *Eastern Fox Squirrel & Sciurus carolinensis & $\mathrm{R}$ & $\mathrm{R}$ & $\mathrm{R}$ \\
\hline *Red Squirrel & Tamiasciurus hudsonicus & & $\mathrm{R}$ & $\mathrm{R}$ \\
\hline *Southern Flying Squirrel & Glaucomys volans & $\mathrm{R}$ & $\mathrm{O}$ & $\mathrm{O}$ \\
\hline *Deer Mouse & Peromyscus maniculatus & $\mathrm{C}$ & $\mathrm{C}$ & A \\
\hline *White-footed Mouse & Peromyscus leucopus & A & A & A \\
\hline *Allegheny Woodrat & Neotoma magister & & & $\mathrm{O}$ \\
\hline *Southern Bog Lemming & Synaptomys cooperi & $\mathrm{O}$ & $\mathrm{O}$ & $\mathrm{C}$ \\
\hline *Red-backed Vole & Clethrionomys gapperi & $\mathrm{C}$ & $\mathrm{C}$ & A \\
\hline *Meadow Vole & Microtus pennsylvanicus & $\mathrm{C}$ & A & $\mathrm{C}$ \\
\hline *Pine (Woodland) Vole & Microtus pinetorum & $\mathrm{R}$ & $\mathrm{R}$ & $\mathrm{O}$ \\
\hline *Yellownose (Rock) Vole & Microtus chrotorrhinus & & & $\mathrm{R}$ \\
\hline *Meadow Jumping Mouse & Zapus hudsonius & $\mathrm{C}$ & A & $\mathrm{C}$ \\
\hline *Woodland Jumping Mouse & Napaeozapus insignis & $\mathrm{C}$ & A & A \\
\hline Black Bear & Ursus americanus & $\mathrm{R}$ & & $\mathrm{R}$ \\
\hline Coyote & Canis latrans & & & $\mathrm{R}$ \\
\hline Domestic Dog & Canis domesticus & & & $\mathrm{R}$ \\
\hline *Raccoon & Procyon lotor & A & A & A \\
\hline *Least Weasel & Mustela rixosa & $\mathrm{R}$ & $\mathrm{R}$ & $\mathrm{R}$ \\
\hline
\end{tabular}


Table 2. Continued.

\begin{tabular}{llccc}
\hline & & \multicolumn{3}{c}{ Relative Abundance $^{\mathrm{ab}}$} \\
\cline { 3 - 5 } Common Name & Scientific Name & $\mathrm{BM}$ & $\mathrm{CA}$ & $\mathrm{PT}$ \\
\hline *Long-tailed Weasel & Mela frenata & $\mathrm{R}$ & $\mathrm{R}$ & $\mathrm{R}$ \\
*Striped Skunk & Felis rufus & & $\mathrm{R}$ \\
Bobcat & Felis domesticus & & $\mathrm{R}$ \\
Domestic Cat & Odocoileus virginianus & $\mathrm{A}$ & $\mathrm{A}$ & $\mathrm{A}$ \\
\hline Whitetail Deer & & & & $\mathrm{R}$ \\
\hline
\end{tabular}

${ }^{\mathrm{a}} \mathrm{BM}=$ Briery Mountain TA, CA $=$ Cantonment Area, PT $=$ Pringle Tract.

${ }^{\mathrm{b}}$ Abundant $(\mathrm{A})=>100$, Common $(\mathrm{C})=20-100$, Occasional $(\mathrm{O})=5-20$, and Rare $(\mathrm{R})=0-5$. 
Table 3. Captures per 100 trap nights for species captured in Sherman live trapping grids on the Cantonment Area (CA) and Pringle Tract (PT) of the Camp Dawson Collective Training Area in Preston County, West Virginia during 2000 and 2001.

\begin{tabular}{|c|c|c|c|c|c|c|c|c|}
\hline \multirow[b]{3}{*}{ Species } & \multicolumn{4}{|c|}{2000} & \multicolumn{4}{|c|}{2001} \\
\hline & \multicolumn{2}{|c|}{$\mathrm{CA}$} & \multicolumn{2}{|c|}{ PT } & \multicolumn{2}{|c|}{ CA } & \multicolumn{2}{|c|}{ PT } \\
\hline & $\bar{x}$ & SE & $\bar{x}$ & SE & $\bar{x}$ & SE & $\bar{x}$ & SE \\
\hline Virginia Opossum & 0.11 & 0.11 & 0.00 & 0.00 & 0.22 & 0.11 & 0.00 & 0.00 \\
\hline Masked Shrew & 0.00 & 0.00 & 0.15 & 0.10 & 0.00 & 0.00 & 0.21 & 0.09 \\
\hline Smoky Shrew & 0.05 & 0.05 & 0.00 & 0.00 & 0.00 & 0.00 & 0.10 & 0.05 \\
\hline Northern Short-tailed Shrew & 1.36 & 0.30 & 0.68 & 0.26 & 2.36 & 0.27 & 2.82 & 0.34 \\
\hline Eastern Chipmunk & 0.59 & 0.18 & 0.15 & 0.10 & 0.76 & 0.18 & 0.79 & 0.18 \\
\hline Red Squirrel & 0.00 & 0.00 & 0.00 & 0.00 & 0.00 & 0.00 & 0.14 & 0.07 \\
\hline Southern Flying Squirrel & 0.32 & 0.14 & 0.29 & 0.13 & 0.08 & 0.06 & 0.43 & 0.13 \\
\hline Peromyscus spp. & 7.68 & 0.93 & 9.87 & 1.38 & 16.67 & 1.51 & 31.34 & 2.07 \\
\hline Allegheny Woodrat & 0.00 & 0.00 & 0.00 & 0.00 & 0.00 & 0.00 & 0.05 & 0.04 \\
\hline Southern Red-backed Vole & 0.06 & 0.06 & 0.60 & 0.27 & 0.18 & 0.11 & 1.99 & 0.39 \\
\hline Meadow Vole & 0.00 & 0.00 & 0.00 & 0.00 & 0.21 & 0.11 & 0.00 & 0.00 \\
\hline Meadow Jumping Mouse & 0.00 & 0.00 & 0.00 & 0.00 & 0.08 & 0.06 & 0.00 & 0.00 \\
\hline Woodland Jumping Mouse & 0.06 & 0.06 & 0.67 & 0.67 & 0.12 & 0.12 & 0.06 & 0.04 \\
\hline Long-tailed Weasel & 0.05 & 0.05 & 0.00 & 0.00 & 0.00 & 0.00 & 0.02 & 0.02 \\
\hline
\end{tabular}


Table 4. Captures per 100 trap nights, Shannon diversity, Pielou evenness, and species richness for small mammals captured in pitfall trapping arrays on the Camp Dawson Collective Training Area in Preston County, West Virginia during 2000 and 2001.

\begin{tabular}{|c|c|c|c|c|c|c|c|c|c|c|}
\hline \multirow[b]{3}{*}{ Species or Index } & \multicolumn{6}{|c|}{ Tract $^{\mathrm{a}}$} & \multicolumn{4}{|c|}{ Year } \\
\hline & \multicolumn{2}{|c|}{$\mathrm{BM}$} & \multicolumn{2}{|c|}{$\mathrm{CA}$} & \multicolumn{2}{|c|}{ PT } & \multicolumn{2}{|c|}{2000} & \multicolumn{2}{|c|}{2001} \\
\hline & $\bar{x}$ & SE & $\bar{x}$ & SE & $\bar{x}$ & SE & $\bar{x}$ & SE & $\bar{x}$ & SE \\
\hline Masked Shrew & $4.477 \mathrm{a}$ & 0.917 & $2.175 \mathrm{a}$ & 0.308 & $3.695 \mathrm{a}$ & 0.574 & $3.997 \mathrm{a}$ & 0.799 & $3.093 \mathrm{a}$ & 0.350 \\
\hline Smoky Shrew & $0.978 \mathrm{a}$ & 0.505 & $0.901 \mathrm{a}$ & 0.187 & $1.370 \mathrm{a}$ & 0.217 & $0.568 \mathrm{~b}$ & 0.179 & $1.462 \mathrm{a}$ & 0.225 \\
\hline Long-tailed Shrew & 0.056 & 0.023 & 0.026 & 0.026 & 0.054 & 0.019 & 0.035 & 0.018 & 0.052 & 0.018 \\
\hline Pygmy Shrew & 0.016 & 0.016 & 0.003 & 0.003 & 0.009 & 0.009 & 0.000 & 0.000 & 0.014 & 0.009 \\
\hline Northern Short-tailed Shrew & $0.483 \mathrm{a}$ & 0.119 & $0.619 \mathrm{a}$ & 0.107 & $1.038 \mathrm{a}$ & 0.164 & $0.408 b$ & 0.079 & $0.993 \mathrm{a}$ & 0.125 \\
\hline Hairy-tailed Mole & 0.000 & 0.000 & 0.020 & 0.013 & 0.002 & 0.002 & 0.000 & 0.000 & 0.011 & 0.007 \\
\hline Star-nosed Mole & 0.004 & 0.004 & 0.046 & 0.019 & 0.011 & 0.009 & 0.000 & 0.000 & 0.031 & 0.011 \\
\hline Eastern Cottontail & 0.000 & 0.000 & 0.003 & 0.003 & 0.004 & 0.004 & 0.005 & 0.005 & 0.002 & 0.002 \\
\hline Eastern Chipmunk & 0.094 & 0.045 & 0.275 & 0.124 & 0.046 & 0.015 & 0.207 & 0.103 & 0.080 & 0.023 \\
\hline Southern Flying Squirrel & 0.004 & 0.004 & 0.003 & 0.003 & 0.000 & 0.000 & 0.000 & 0.000 & 0.003 & 0.002 \\
\hline Peromyscus spp. & $1.220 \mathrm{~b}$ & 0.329 & $1.300 \mathrm{~b}$ & 0.266 & $2.634 \mathrm{a}$ & 0.327 & $1.705 \mathrm{a}$ & 0.228 & $2.005 \mathrm{a}$ & 0.295 \\
\hline Southern Red-backed Vole & 0.314 & 0.106 & 0.207 & 0.079 & 0.285 & 0.074 & 0.171 & 0.065 & 0.325 & 0.065 \\
\hline
\end{tabular}


Table 4. Continued

\begin{tabular}{|c|c|c|c|c|c|c|c|c|c|c|}
\hline \multirow[b]{3}{*}{ Species or Index } & \multicolumn{6}{|c|}{ Tract $^{\mathrm{ab}}$} & \multicolumn{4}{|c|}{ Year $^{\mathrm{b}}$} \\
\hline & \multicolumn{2}{|c|}{$\mathrm{BM}$} & \multicolumn{2}{|c|}{$\mathrm{CA}$} & \multicolumn{2}{|c|}{$\mathrm{PT}$} & \multicolumn{2}{|c|}{2000} & \multicolumn{2}{|c|}{2001} \\
\hline & $\bar{x}$ & SE & $\bar{x}$ & SE & $\bar{x}$ & SE & $\bar{x}$ & SE & $\bar{x}$ & SE \\
\hline Meadow Vole & 0.310 & 0.104 & 1.012 & 0.344 & 0.483 & 0.140 & 0.626 & 0.177 & 0.587 & 0.175 \\
\hline Rock Vole & 0.000 & 0.000 & 0.000 & 0.000 & 0.020 & 0.020 & 0.025 & 0.025 & 0.000 & 0.000 \\
\hline Woodland Vole & 0.008 & 0.008 & 0.030 & 0.023 & 0.046 & 0.020 & 0.034 & 0.021 & 0.031 & 0.014 \\
\hline Southern Bog Lemming & 0.106 & 0.048 & 0.133 & 0.047 & 0.151 & 0.037 & 0.154 & 0.043 & 0.124 & 0.031 \\
\hline Meadow Jumping Mouse & 0.231 & 0.081 & 3.625 & 1.385 & 0.571 & 0.171 & 2.986 & 1.174 & 0.506 & 0.133 \\
\hline Woodland Jumping Mouse & $0.130 \mathrm{~b}$ & 0.030 & $1.588 \mathrm{a}$ & 0.632 & $1.622 \mathrm{a}$ & 0.323 & $1.568 \mathrm{a}$ & 0.561 & $1.079 \mathrm{a}$ & 0.232 \\
\hline Least Weasel & 0.004 & 0.004 & 0.000 & 0.000 & 0.013 & 0.009 & 0.000 & 0.000 & 0.011 & 0.007 \\
\hline Long-tailed Weasel & 0.008 & 0.008 & 0.000 & 0.000 & 0.004 & 0.004 & 0.010 & 0.007 & 0.000 & 0.000 \\
\hline Total & 8.469 & 1.499 & 11.994 & 1.838 & 12.057 & 1.192 & 12.583 & 1.686 & 10.379 & 0.954 \\
\hline Shannon Diversity & $1.497 b$ & 0.067 & $1.664 \mathrm{ab}$ & 0.098 & $1.779 \mathrm{a}$ & 0.037 & $1.577 \mathrm{a}$ & 0.073 & $1.735 \mathrm{a}$ & 0.044 \\
\hline Pielou Evenness & $0.708 b$ & 0.025 & $0.773 \mathrm{ab}$ & 0.030 & $0.796 \mathrm{a}$ & 0.015 & $0.745 \mathrm{a}$ & 0.028 & $0.781 \mathrm{a}$ & 0.013 \\
\hline Species Richness & $1.412 \mathrm{a}$ & 0.262 & $1.668 \mathrm{a}$ & 0.236 & $1.727 \mathrm{a}$ & 0.208 & $2.133 \mathrm{a}$ & 0.259 & $1.347 \mathrm{~b}$ & 0.131 \\
\hline
\end{tabular}

${ }^{\mathrm{a}} \mathrm{BM}=$ Briery Mountain TA, $\mathrm{CA}=$ Cantonment Area, $\mathrm{PT}=$ Pringle Tract.

${ }^{\mathrm{b}}$ The same letter following means indicates no difference among tract or year $(P>0.05)$. 
Table 5. Shannon Diversity, Pielou's Evenness Index, Species Richness, Sorenson Community Similarity Index, and number of arrays by vegetative community (Vanderhorst 2001) for small mammals captured in pitfall traps on the Camp Dawson Collective Training Area in Preston County, West Virginia during 2000 and 2001.

\begin{tabular}{|c|c|c|c|c|c|c|c|c|}
\hline \multirow[b]{2}{*}{ Vegetation Community } & \multirow{2}{*}{$\begin{array}{l}\text { Number of } \\
\text { Arrays }\end{array}$} & \multirow{2}{*}{$\begin{array}{l}\text { Sorenson } \\
\text { Index }^{\mathrm{b}}\end{array}$} & \multicolumn{2}{|c|}{ Shannon Diversity $^{\mathrm{a}}$} & \multicolumn{2}{|c|}{ Pielou Evenness $^{\mathrm{a}}$} & \multicolumn{2}{|c|}{ Species Richness $^{\mathrm{a}}$} \\
\hline & & & $x$ & SE & $\bar{x}$ & SE & $\bar{x}$ & $\mathrm{SE}$ \\
\hline Developed & 2 & 77 & $1.883 \mathrm{a}$ & 0.175 & $0.848 \mathrm{a}$ & 0.033 & $2.843 \mathrm{a}$ & 0.475 \\
\hline Hemlock Ravine & 1 & 77 & $1.878 \mathrm{a}$ & 0.025 & $0.786 \mathrm{abc}$ & 0.040 & $0.975 \mathrm{a}$ & 0.353 \\
\hline $\begin{array}{l}\text { Mixed Mesophytic Forest of } \\
\text { Colluvial Slopes }\end{array}$ & 8 & 94 & $1.849 \mathrm{ab}$ & 0.054 & $0.841 \mathrm{a}$ & 0.018 & $1.502 \mathrm{a}$ & 0.271 \\
\hline Successional Floodplain Forest & 3 & 73 & $1.775 \mathrm{ab}$ & 0.072 & $0.790 \mathrm{abc}$ & 0.025 & 0.836 & 0.117 \\
\hline Old Field & 8 & 88 & $1.768 \mathrm{ab}$ & 0.070 & $0.810 \mathrm{ab}$ & 0.025 & $1.648 \mathrm{a}$ & 0.341 \\
\hline $\begin{array}{l}\text { Successional Forest of Low } \\
\text { Elevation Plains }\end{array}$ & 7 & 88 & $1.739 \mathrm{ab}$ & 0.076 & $0.766 \mathrm{abc}$ & 0.024 & $1.564 \mathrm{a}$ & 0.396 \\
\hline Road & 1 & 59 & $1.643 \mathrm{ab}$ & 0.065 & $0.798 \mathrm{ab}$ & 0.080 & $2.668 \mathrm{a}$ & 0.429 \\
\hline Pine Plantation & 2 & 73 & $1.633 \mathrm{abc}$ & 0.082 & $0.709 \mathrm{abc}$ & 0.036 & $1.485 \mathrm{a}$ & 0.543 \\
\hline $\begin{array}{l}\text { Mixed Montane Hardwood } \\
\text { Forest }\end{array}$ & 4 & 77 & $1.515 \mathrm{abc}$ & 0.080 & $0.715 \mathrm{abc}$ & 0.032 & $1.877 \mathrm{a}$ & 0.483 \\
\hline
\end{tabular}


Table 5. Continued.

\begin{tabular}{|c|c|c|c|c|c|c|c|c|}
\hline \multirow[b]{2}{*}{ Vegetation Community } & \multirow{2}{*}{$\begin{array}{c}\text { Number of } \\
\text { Arrays }\end{array}$} & \multirow{2}{*}{$\begin{array}{c}\text { Sorenson } \\
\text { Index }^{b}\end{array}$} & \multicolumn{2}{|c|}{ Shannon Diversity ${ }^{\mathrm{a}}$} & \multicolumn{2}{|c|}{ Pielou Evenness $^{\mathrm{a}}$} & \multicolumn{2}{|c|}{ Species Richness $^{\mathrm{a}}$} \\
\hline & & & $\bar{x}$ & SE & $\bar{x}$ & SE & $\bar{x}$ & SE \\
\hline Disturbed & 1 & 59 & $1.476 \mathrm{abc}$ & 0.380 & $0.728 \mathrm{abc}$ & 0.117 & $2.449 \mathrm{a}$ & 0.254 \\
\hline Sub-Xeric Oak Forest & 1 & 69 & $1.248 \mathrm{bc}$ & 0.131 & $0.568 \mathrm{c}$ & 0.031 & $0.807 \mathrm{a}$ & 0.319 \\
\hline Agricultural Land & 2 & 54 & $1.013 \mathrm{c}$ & 0.217 & $0.592 b c$ & 0.085 & $1.976 \mathrm{a}$ & 0.567 \\
\hline
\end{tabular}

${ }^{a}$ The same letter following means in a column indicates no difference $(P>0.05)$.

${ }^{\mathrm{b}}$ Sorenson Indices represent a comparison of each vegetative community to the pooled community of all other vegetative community types 
Table 6. Mean number of calls recorded per monitoring session with test values for Chiropteran species captured on the Camp Dawson Collective Training Area in Preston County, West Virginia during 2000 and 2001.

\begin{tabular}{|c|c|c|c|c|c|c|c|c|}
\hline \multirow[b]{3}{*}{ Species } & \multicolumn{6}{|c|}{$\operatorname{Tract}^{\mathrm{a}}$} & \multirow[b]{3}{*}{$F_{2,16}$} & \multirow[b]{3}{*}{$P$} \\
\hline & \multicolumn{2}{|c|}{$\mathrm{BM}$} & \multicolumn{2}{|c|}{$\mathrm{CA}$} & \multicolumn{2}{|c|}{$\mathrm{PT}$} & & \\
\hline & $\bar{x}$ & SE & $\bar{x}$ & SE & $\bar{x}$ & SE & & \\
\hline Eastern Pipistrelle & 0.33 & 0.33 & 1.10 & 0.62 & 13.50 & 7.14 & 2.92 & 0.083 \\
\hline Big Brown Bat & 9.00 & 4.93 & 9.00 & 6.58 & 3.25 & 1.60 & 1.30 & 0.301 \\
\hline Little Brown Bat & 1.67 & 1.20 & 10.90 & 10.13 & 8.38 & 4.88 & 0.66 & 0.529 \\
\hline Northern Long-eared Myotis & 0.33 & 0.33 & 0.00 & 0.00 & 1.88 & 0.69 & 3.05 & 0.076 \\
\hline Eastern Red Bat & 1.33 & 0.67 & 0.10 & 0.10 & 2.75 & 1.16 & 0.68 & 0.521 \\
\hline Hoary Bat & 0.00 & 0.00 & 3.50 & 3.28 & 0.50 & 0.38 & 0.38 & 0.692 \\
\hline
\end{tabular}

${ }^{\mathrm{a}} \mathrm{BM}=$ Briery Mountain, $\mathrm{CA}=$ Cantonment Area, $\mathrm{PT}=$ Pringle Tract. 
Table 7. Mammals and birds recorded at scent stations on the Camp Dawson Collective Training Area in Preston County, West Virginia during 2000 and 2001.

\begin{tabular}{|c|c|c|c|}
\hline \multirow[b]{2}{*}{ Common Name } & \multicolumn{3}{|c|}{ Number of Visits $^{\mathrm{a}}$} \\
\hline & $\mathrm{BM}$ & $\mathrm{CA}$ & PT \\
\hline Virginia Opossum & 2 & 8 & 7 \\
\hline Black Bear & 1 & 2 & 6 \\
\hline Raccoon & 11 & 11 & 13 \\
\hline Weasel spp. & 0 & 0 & 1 \\
\hline Striped Skunk & 0 & 1 & 1 \\
\hline Bobcat & 0 & 0 & 4 \\
\hline Coyote & 1 & 0 & 1 \\
\hline domestic dog & 0 & 0 & 1 \\
\hline domestic cat & 0 & 2 & 1 \\
\hline Eastern Chipmunk & 9 & 4 & 4 \\
\hline Eastern Gray Squirrel & 0 & 3 & 4 \\
\hline Eastern Cottontail & 1 & 1 & 6 \\
\hline White-tailed Deer & 11 & 6 & 12 \\
\hline Man & 3 & 0 & 1 \\
\hline Small mammal tracks & 28 & 13 & 32 \\
\hline Small bird tracks & 13 & 5 & 8 \\
\hline Medium bird tracks & 0 & 2 & 1 \\
\hline
\end{tabular}

${ }^{\mathrm{a}} \mathrm{BM}=$ Briery Mountain, $\mathrm{CA}=$ Cantonment Area, $\mathrm{PT}=$ Pringle Tract. 

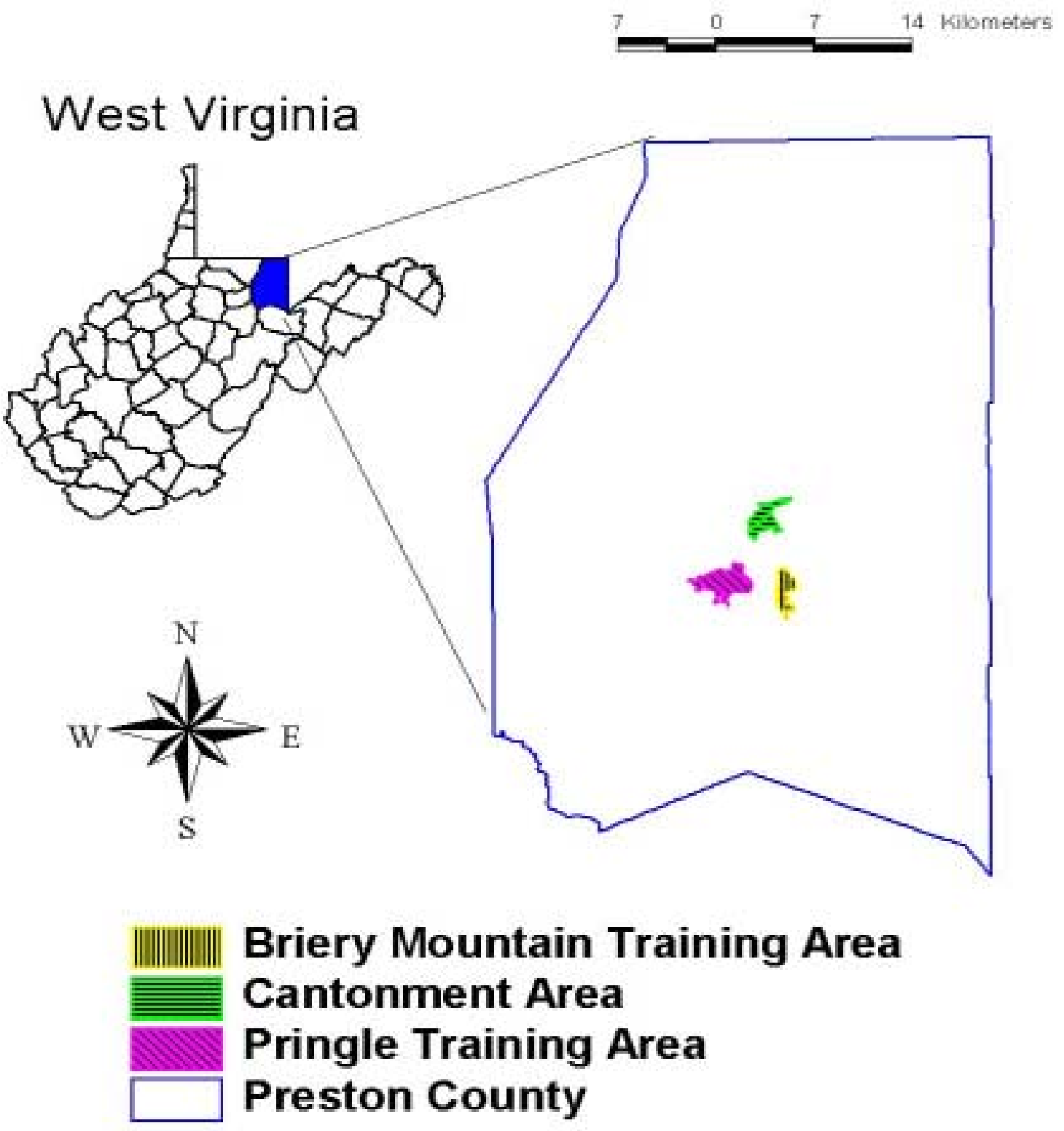

Figure 1. The Camp Dawson Collective Training Area in Preston County, West Virginia. 


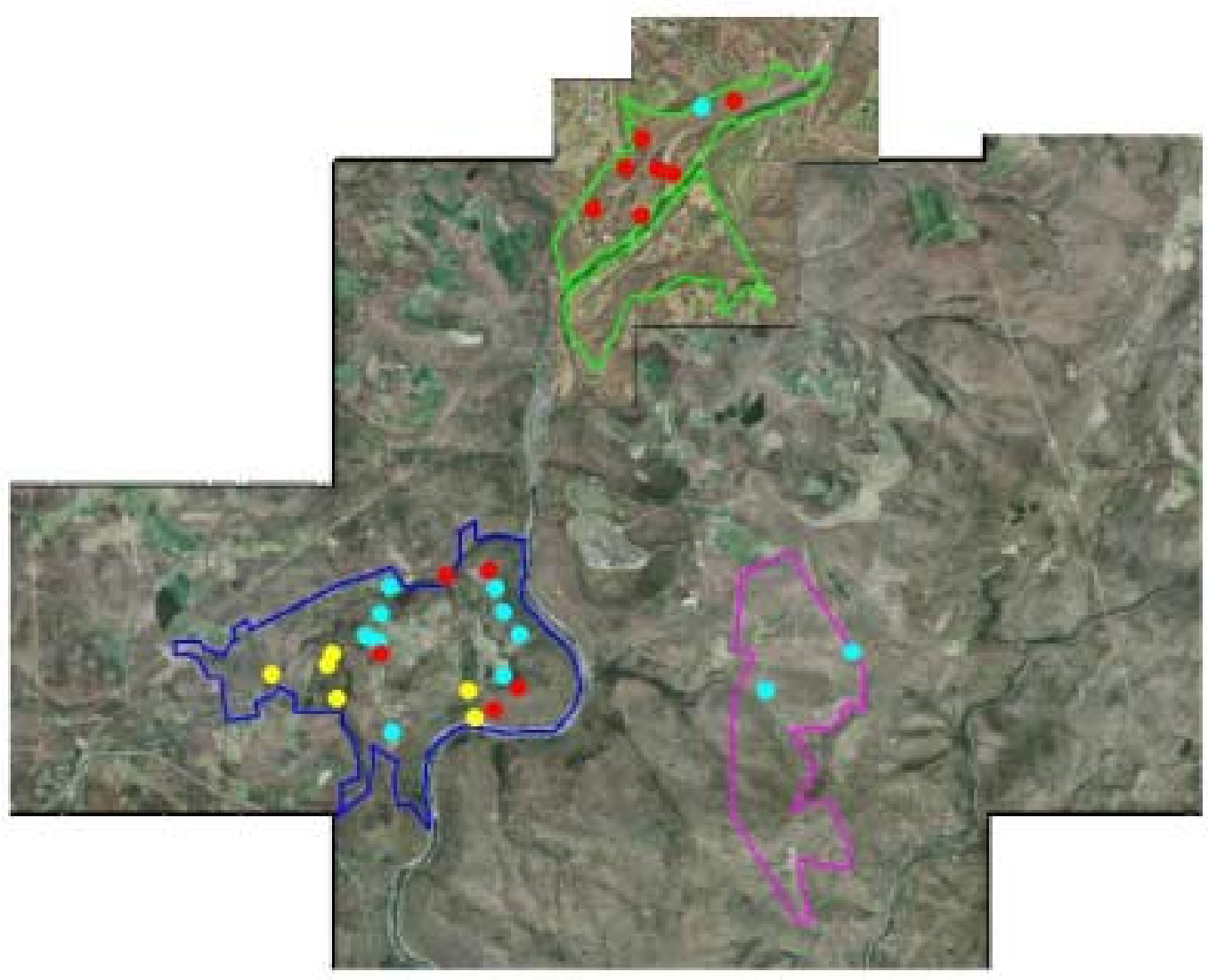

Sherman Grids (Added in 2001)

- Sherman Grids (selected 2000)

- Sherman Grids (not selected)

Cantonment Area Boundary

Pringle TA Boundary

Briery Mountain TA Boundary

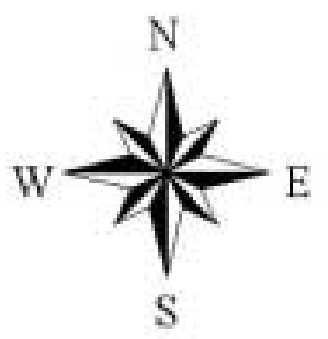

3

0

3

6 Kilometers

Figure 2. Locations of Sherman live trapping grids on the Pringle Training Area of the Camp Dawson Collective Training Area in Preston County, West Virginia during 2000 and 2001. Sites in blue were trapped once in 2000 and not selected for this study. Sites in red were selected and trapped in 2000 and 2001. Sites in yellow were added in 2001. 


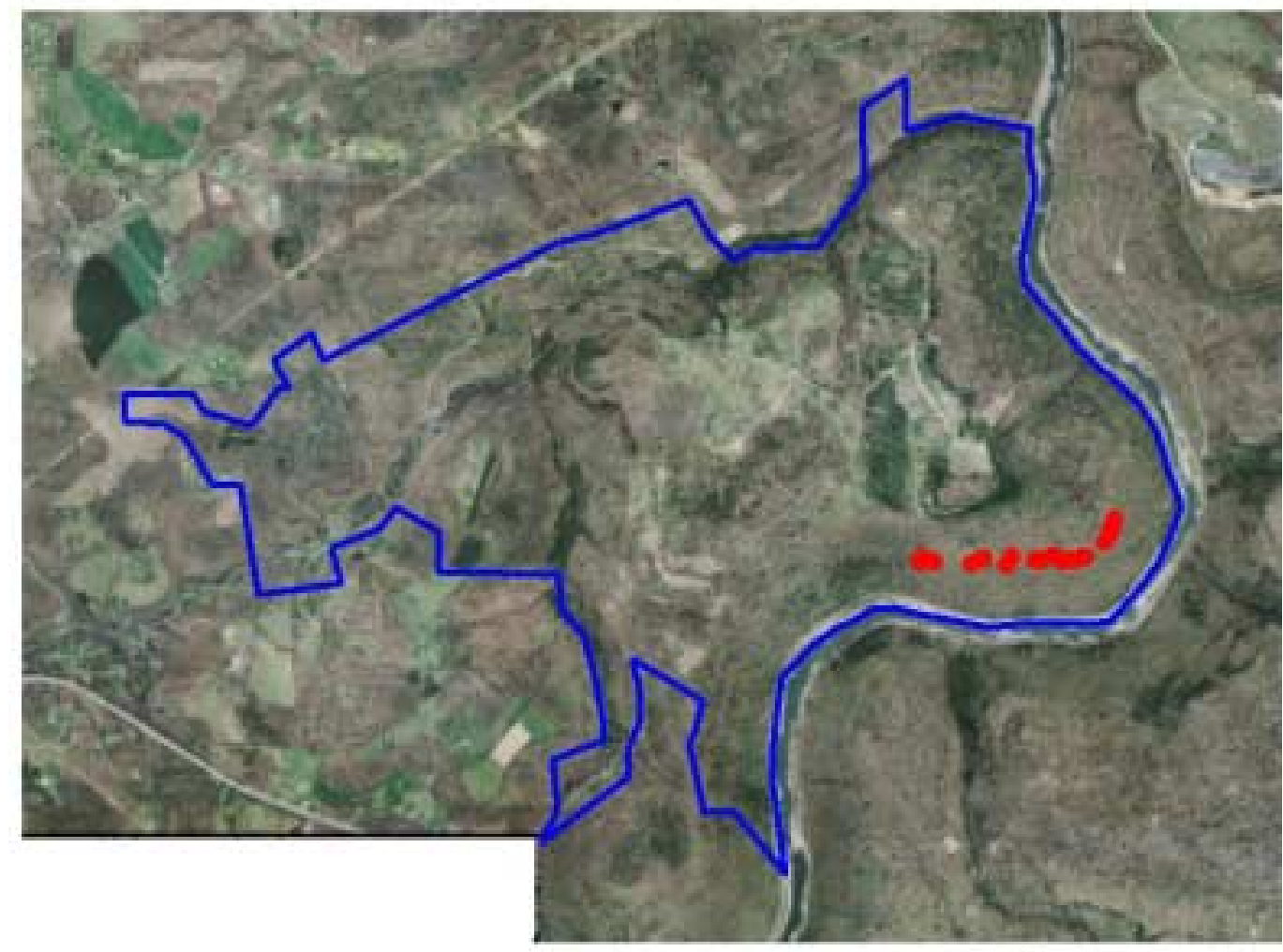

\section{- Woodrat Trapping Points Pringle TA Boundary}
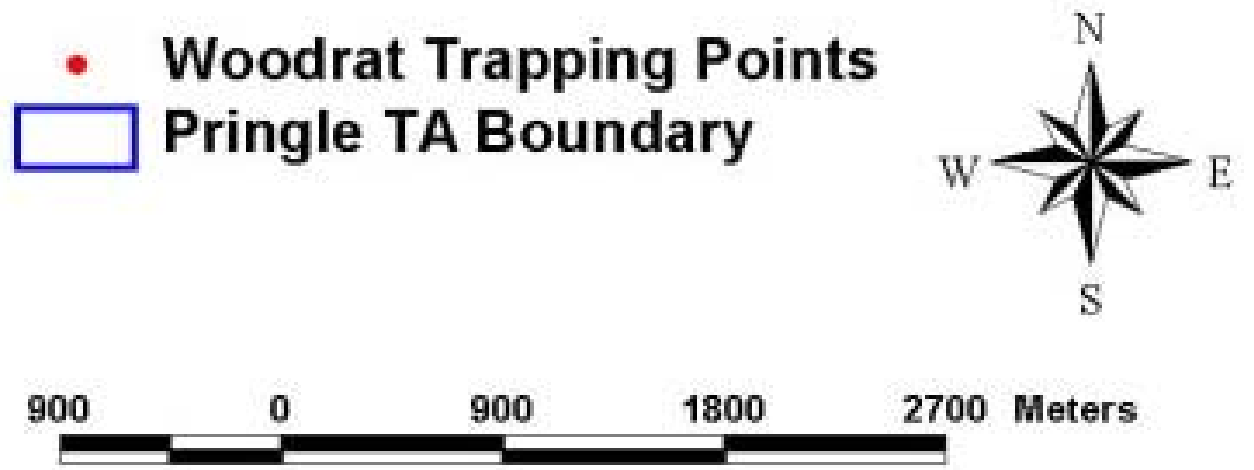

Figure 3. Locations of Allegheny Woodrat (Neotoma magister) trapping sites on the

Pringle Training Area of the Camp Dawson Collective Training Area in Preston County, West Virginia during fall 2000. 


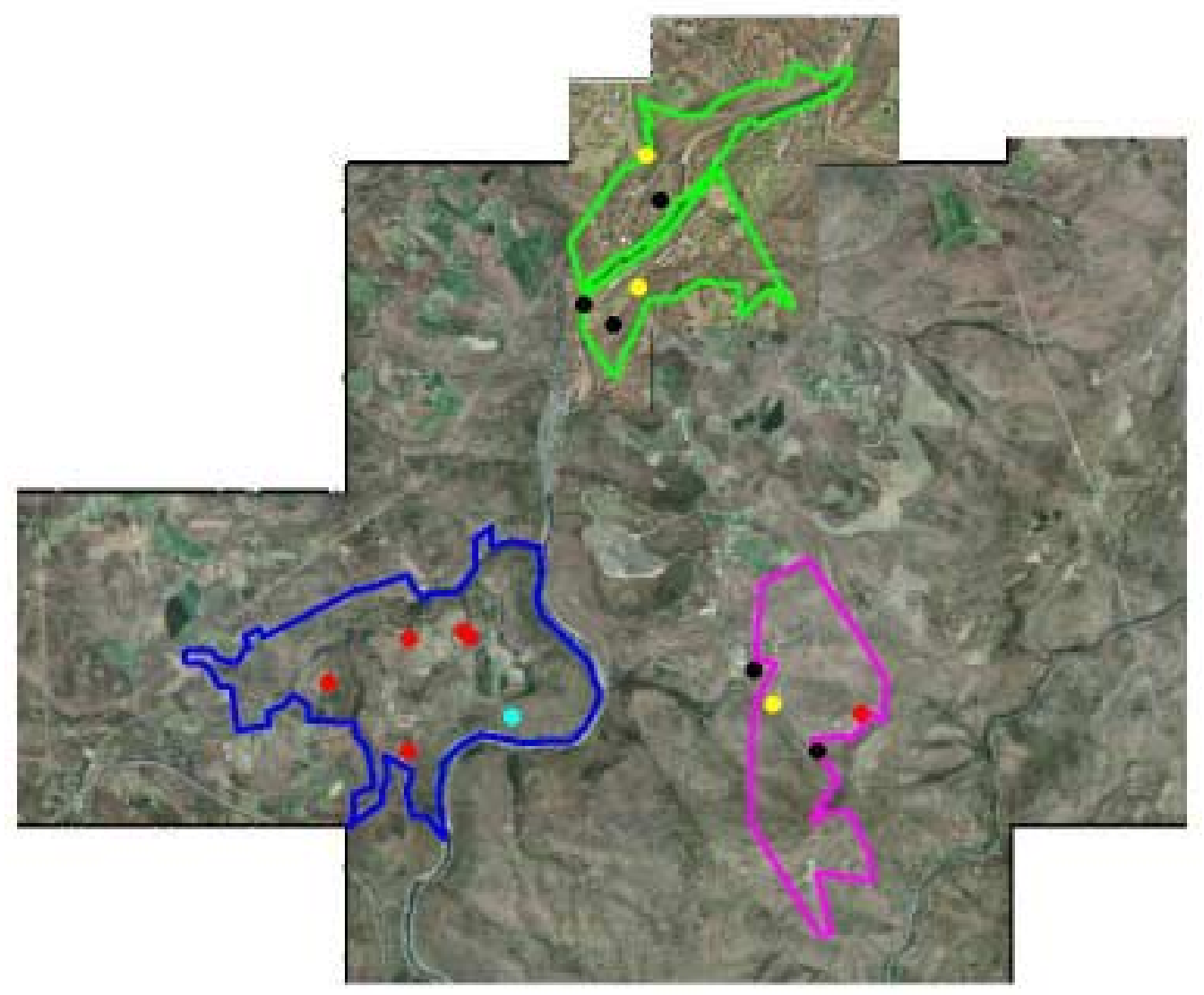

Tomahawk Grids 2000

Tomahawk Grids 2001

- Snap Trap Grids 2000

- Snap Trap Grids 2001

Cantonment Area Boundary

Pringle TA Boundary

Briery Mountain TA Boundary
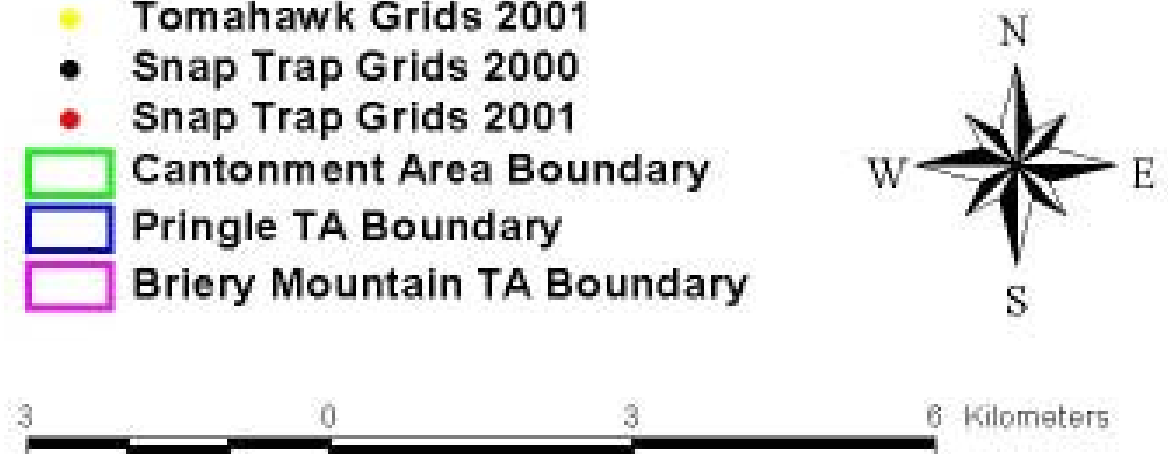

Figure 4. Locations of Tomahawk live trapping grids and Museum Special snap trapping grids on the Camp Dawson Collective Training Area in Preston County, West Virginia during 2000 and 2001. Sites in blue are Tomahawk grids trapped in 2000. Sites in yellow are Tomahawk trapped in 2001. Sites in black are snap trap grids trapped in 2000 . Sites in red are snap trap grids trapped in 2001. 


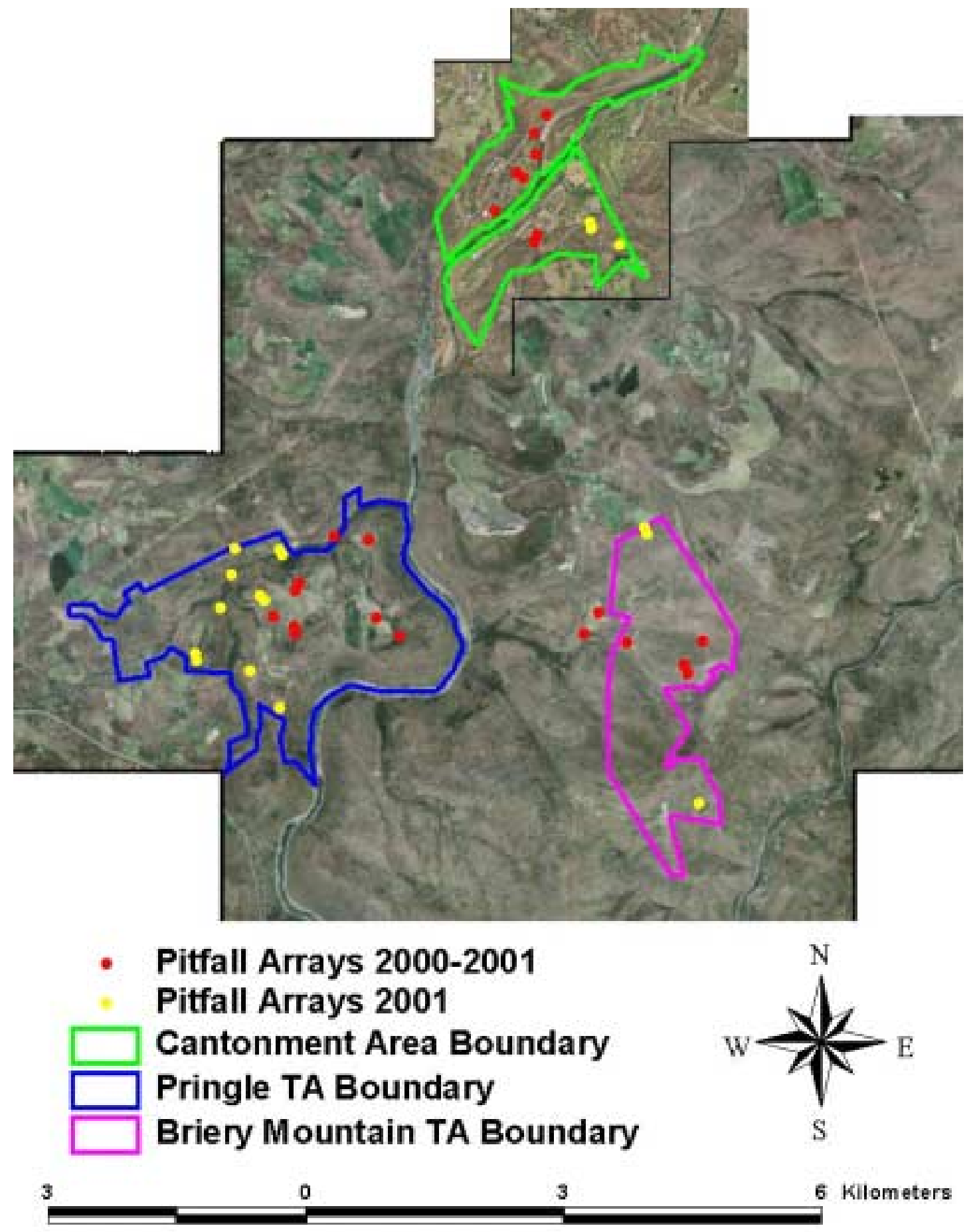

Figure 5. Locations of pitfall trapping arrays on the Camp Dawson Collective Training Area in Preston County, West Virginia during 2000 and 2001. Sites in red were trapped in 2000 and 2001. Sites in yellow were trapped in 2001. 


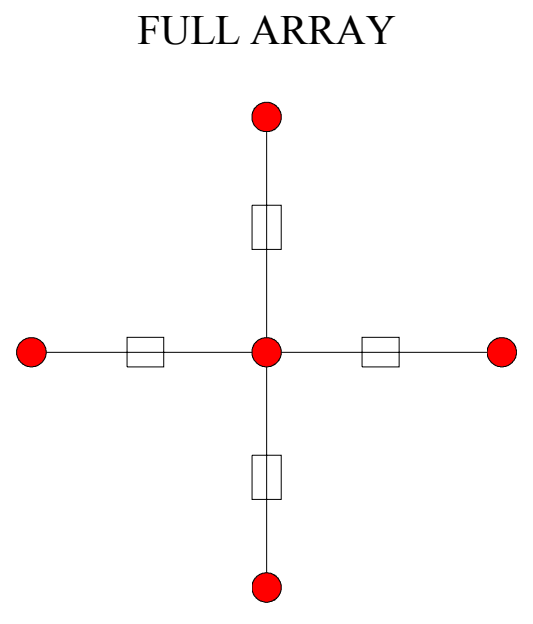

TRANSECT ARRAY

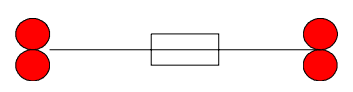

Figure 6. Diagram of pitfall arrangements used on the Camp Dawson Collective Training Area in Preston County, West Virginia during 2000 and 2001. Full arrays have 4 drift fences and 5 pitfall buckets. Transect arrays have 1 fence and 4 pitfall buckets. $==$ drift fence, $\bullet=$ pitfall trap. 

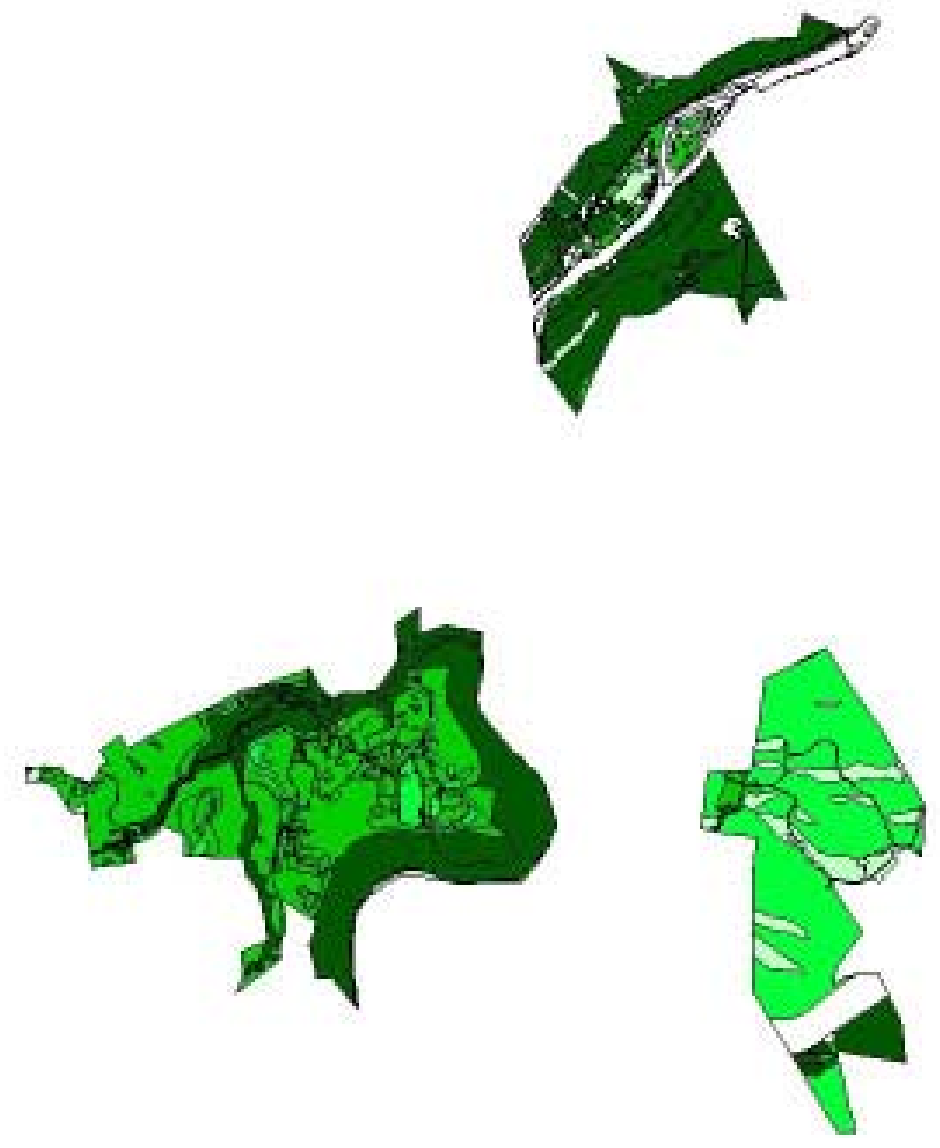

Shannon Diversity Index

\begin{tabular}{|c|}
\hline $1.776-1.883$ \\
\hline $1.477-1.644$ \\
\hline $\begin{array}{l}1.013-1.476 \\
\text { No Data }\end{array}$ \\
\hline
\end{tabular}
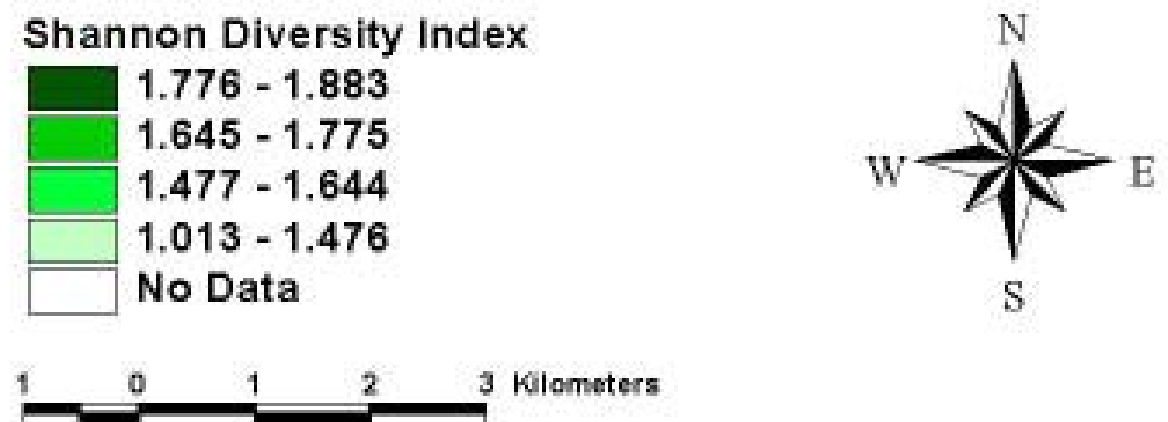

Figure 7. Shannon Diversity Index values by vegetative community for small mammals caught in pitfall traps on the Camp Dawson Collective Training Area during 2000 and 2001. 


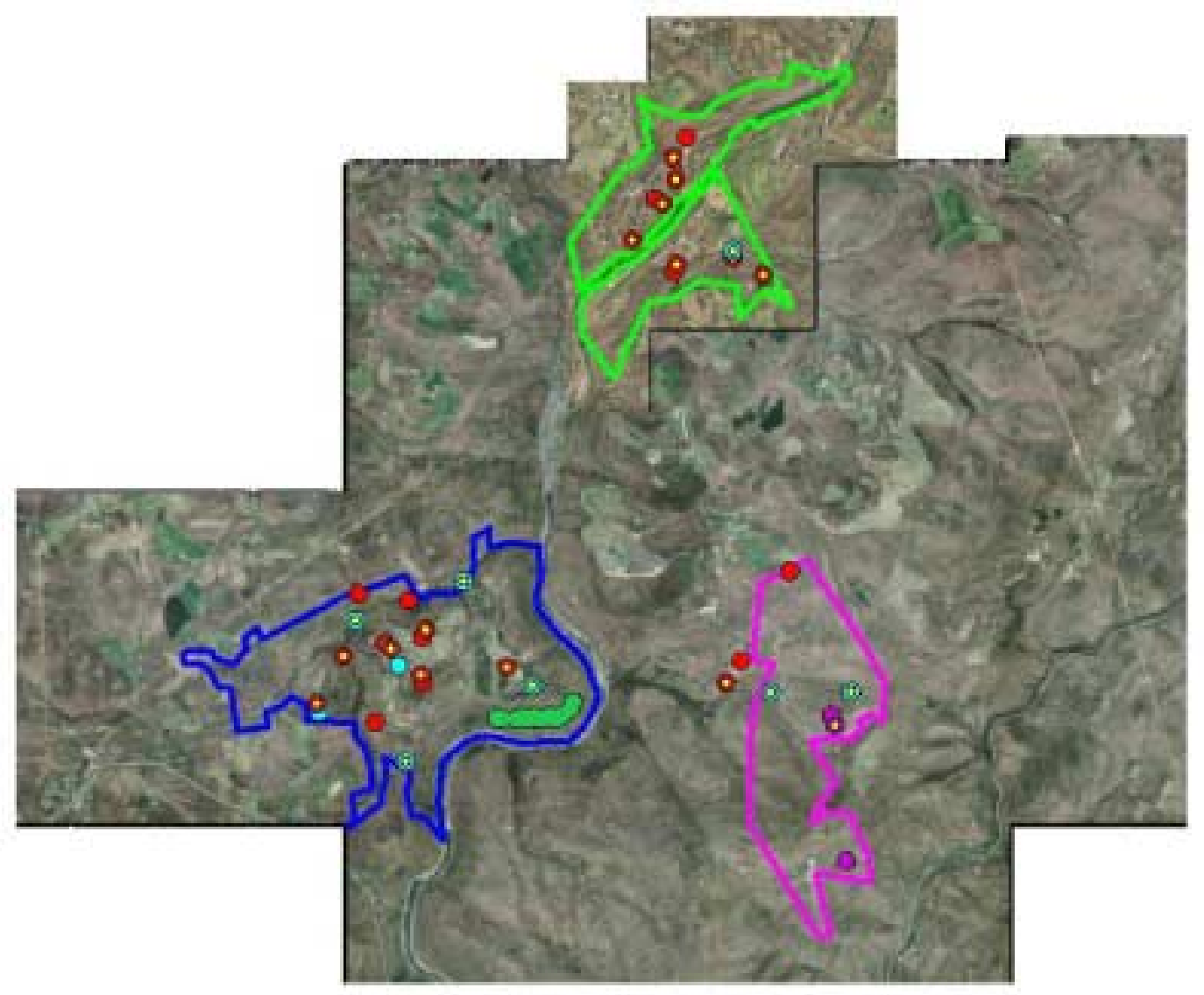

Buffer Zones

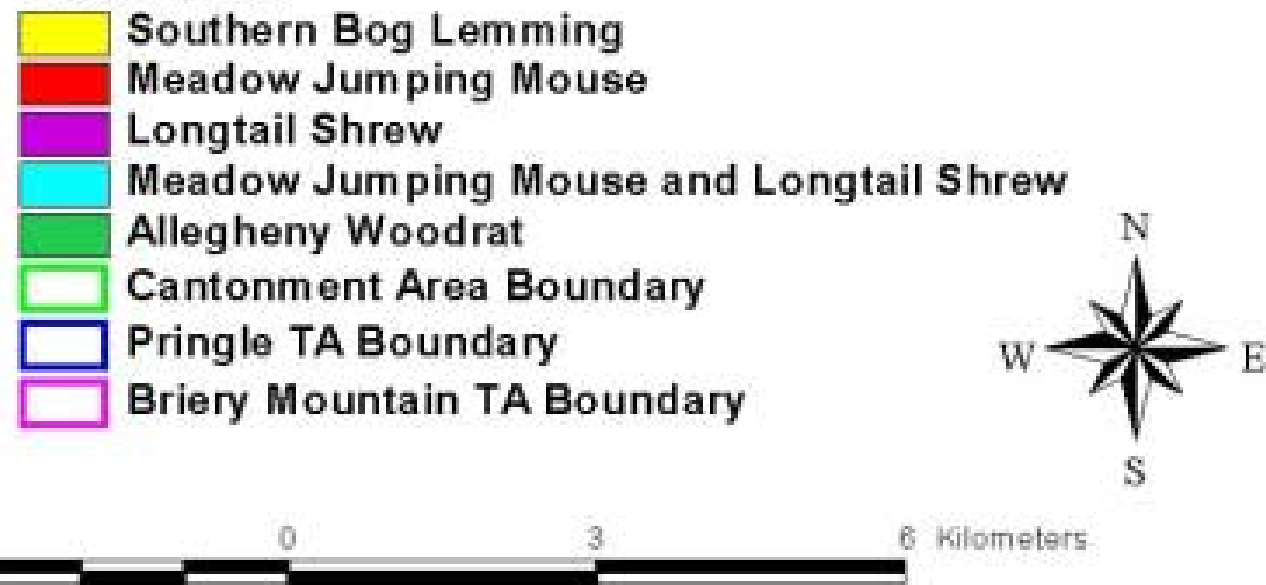

Figure 8. Buffer zones around trapping locations where West Virginia state rare mammal species were captured on the Camp Dawson Collective Training Area in Preston County, West Virginia during 2000 and 2001 (WVDNR 2000). 


\section{CHAPTER II}

Small Mammal Response to Coarse Woody Debris in the Central Appalachians

Abstract: Response of small mammal populations to manipulation of coarse woody debris (CWD) volume was tested in central Appalachian forests in Preston County, West Virginia from 2000-2001. Abundance and diversity measures of small mammals $(\underline{\mathrm{N}}=$ 1,564) captured on 18 experimental $60 \times 60 \mathrm{~m}$ live-trapping grids were compared. Grids were randomly distributed between addition sites (volume of CWD increased by 50\%), removal sites (volume of CWD reduced by 50\%), and control sites. Grids were classified as edge $(<100 \mathrm{~m}$ from a forest edge) or interior $(\geq 100 \mathrm{~m}$ from a forest edge). A splitplot analysis of variance (ANOVA) was used to compare abundance and diversity measures of small mammals among the CWD manipulation classes on average after manipulations and temporally by trapping session for 2 separate models. The first model (Model I) included all grids established and manipulated in 2000 and trapped in 2000 and $2001(\underline{N}=12)$. The second model (Model II) included $1^{\text {st }}$ year trapping data for the original 12 grids and 6 new grids established and manipulated in $2001(\underline{\mathrm{N}}=18)$. A total of 15 species was sampled in 13,009 trap nights. The most abundant species captured

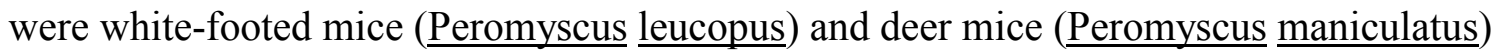
(analyzed together as Peromyscus spp. 74\%), northern short-tailed shrews (Blarina brevicauda) (12\%), and southern red-backed voles (Clethrionomys gapperi) (5\%). Diversity estimates were similar among CWD manipulation classes except for average species richness, which was higher in removal sites $(\underline{\mathrm{x}}=3.08, \mathrm{SE}=0.20)$ than control sites $(\underline{x}=2.38, \mathrm{SE}=0.15)$ after CWD manipulations in model $\mathrm{I}(\underline{\mathrm{F}}=6.49, \mathrm{df}=2,30, \underline{\mathrm{P}}=$ This Chapter written in the style of Proceedings of the Annual Southeast Conference 
and through time with the exception of southern red-backed voles, which were more abundant in interior removal sites. Average mass of Peromyscus spp. was greater in removal sites than control sites after manipulations $(\underline{F}=4.38, \mathrm{df}=2,395, \underline{\mathrm{P}}=0.040)$. These results suggest that manipulation of CWD volume through removal or addition has little short-term effect on abundance, diversity, or condition of small mammals in the Central Appalachians.

Proc. Annu. Conf. Southeast. Assoc. Fish and Wildl. Agencies : -

Many studies have described coarse woody debris (CWD) as an important component of vertebrate microhabitats (Barry and Francq 1980, Harmon et al. 1986, Graves et al. 1988, Freedman et al. 1996, Bowman et al. 2000, Butts and McComb 2000). For instance, in the Blue Mountains of Oregon and Washington, Thomas (1979) described 179 vertebrate species, including numerous small mammal species, that in some way used CWD. The white-footed mouse is a common species throughout the eastern United States, and several studies have demonstrated the use of CWD by this species and the closely related deer mouse (Barry and Francq 1980, Graves et al. 1988, Barnum et al. 1992, Planz and Kirkland 1992, McMillan and Kaufman 1995) (Scientific names follow Wilson and Reeder [1993]). Several studies also have investigated the relationship of various vole species with CWD (Gunderson 1959, Miller and Getz 1977, Hayes and Cross 1987, Nordyke and Buskirk 1991, Tallmon and Mills 1994, Bowman et al. 2000). However, little of this work was conducted in eastern deciduous hardwood forests. The largest volume of the work on the importance of CWD to small mammal populations has been conducted in the Pacific Northwest (Lee 1993 and 1995, Tallmon 
and Mills 1994, Carey and Johnson 1995, Butts and McComb 2000). In addition, few of the studies that have been conducted in the eastern United States answered questions about the effect of different volumes of CWD on small mammal communities (Bowman et al. 1999, Loeb 1999).

The study site for my research, similar to many forested areas in the Central Appalachians, is heavily affected by logging practices that cause alterations in CWD volume (McCarthy and Bailey 1994, WVARNG 2001). The effect of these habitat manipulations is of interest to wildlife managers concerned with maintaining biological diversity in Central Appalachian forests. The objectives of this study were to compare small mammal abundance, diversity, and condition in plots where CWD volumes were decreased, plots with increased CWD volumes, and control sites.

\section{METHODS}

Study Area

This study was conducted on the Camp Dawson Collective Training Area (CDCTA) in north-central (Preston County), West Virginia. Three tracts of land, the Cantonment Area (378 ha), the Briery Mountain Training Area (TA) (423 ha), and the Pringle TA (854 ha), comprise the 1,665 ha of the CDCTA which is centered on $39^{\circ} 26^{\prime}$ north latitude and $79^{\circ} 40^{\prime}$ west longitude in the Cheat River watershed (WVARNG 2001) (Chapter I). The land is primarily used for military activity, logging, and public recreation (WVARNG 2001). The primary cover types on the CDCTA are mixed mesophytic forest, mixed montane hardwood forest, and successional forest of low elevation plains (Vanderhorst 2001). The most common tree species on the study area 


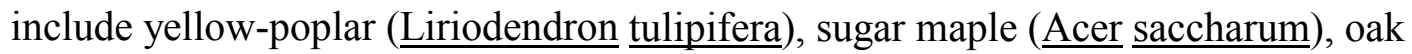
(Quercus spp.), hickory (arya spp.), black locust (ㅁobinia pseudoacacia), and black cherry (Prunus serotina) (Vanderhorst 2001). The primary soils on the study area are loams, silt loams, and rubbly complexes (Bell 2001).

\section{Mammal Trapping}

Small mammal live trapping grids were established on 25 sites from 26 June to 1 September 2000. Of the 25 established grids, 12 were selected on the Pringle TA and Cantonment Area for use in the CWD manipulation study (Chapter I). The other grids were eliminated because of limited data caused by carnivore disturbance of trapping grids. The initial trapping session occurred from 26 June 2000 to 1 September 2000. After vegetation was sampled (20 August 2000 to 1 September 2000), CWD manipulations were conducted from 8 September 2000 to 29 October 2000. Each site was trapped within 24 hours of the completion of manipulations at that site in a second trapping session from 9 September to 1 November 2000. Finally, a third period of live trapping in the first field season was conducted on the selected sites from 30 October 2000 to 16 November 2000. In 2001, 6 new grids were trapped from 10 May 2001 to 24 May 2001. Vegetative sampling was conducted from 29 May 2001 to 20 June 2001 on the 6 new grids and the 12 original grids, and CWD manipulations were conducted on the new grids from 21 June 2001 to 13 July 2001. Each of the new sites was trapped within 24 hours of manipulation at that grid, and the 12 original grids were trapped from 14 July 2001 to 17 August 2001. The 18 manipulated grids were then trapped approximately once a month in 3 more trapping sessions from 18 August 2001 to 4 December 2001. 
Each experimental site was a $60 \times 60 \mathrm{~m}$ grid with 49 trapping stations equally spaced 10 m apart (Laerm et al. 1997, Jorgensen et al. 1998, Loeb 1999). At each station, we placed 1 collapsible $7.7 \times 7.7 \times 23 \mathrm{~cm}$ Sherman aluminum box trap and installed a 0.946 L plastic pitfall cup (Laerm et al. 1997, Jorgensen et al. 1998, Menzel et al. 1999). Each Sherman trap was baited with about $10 \mathrm{~g}$ of rolled peanut butter and oats (Sullivan and Sullivan 1980, Carey and Johnson 1995). Species, mass, sex, and reproductive condition were recorded for each animal caught (Laerm et al. 1995, Menzel et al. 1999). The 2 Peromyscus species that occur in this region, white-footed mouse and deer mouse, were combined and analyzed as Peromyscus spp. to eliminate possible error associated with morphological identification of these species and to provide better estimates of abundance of the genus as a whole (Merritt 1987). Live mice, chipmunks, and squirrels were ear-tagged, and live shrews were toe-clipped (Laerm et al. 1995, Menzel et al. 1999). Dead specimens were collected for later identification and preservation in the West Virginia University Vertebrate Collection.

\section{Habitat Sampling and CWD Manipulations}

Habitat sampling was conducted on the 12 selected sites in 2000, and all 18 grids in 2001. Initially, each site was classified as riparian or upland with riparian sites located $<100 \mathrm{~m}$ from any type of water source, and upland sites $\geq 100 \mathrm{~m}$ from water on all sides (Laerm et al. 1997). Grids were further stratified by distance to forest edge. Edge sites had all side $<100 \mathrm{~m}$ from a forest edge, and interior sites had all sides $\geq 100 \mathrm{~m}$ from the forest edge. At each grid, basal area was measured with a 10-factor prism at the center of the trapping grid (Avery and Burkhart 1983, Laerm et al. 1997). Vegetation sampling 
was conducted at each trap station for a total of 49 quadrats per grid. A $1 \times 1 \mathrm{~m}^{2}$ quadrat was established with the southeast corner of the quadrat located on the selected sampling point. Length and diameter of all CWD in the quadrat were recorded for calculation of CWD volume. A caliper was used to measure CWD diameter at the midpoint of each log inside the sample quadrat. Coarse woody debris was considered any downed $\log >10 \mathrm{~cm}$ in diameter (Harmon et al. 1986, Spies and Cline 1988, Loeb 1999, Butts and McComb 2000). Volume of CWD was calculated for the grid including a 10-m buffer zone on all sides by calculating the volume in each subplot, adding those values, and extrapolating to the full size of the grid. Thus, CWD volume for a grid was estimated for the $6,400 \mathrm{~m}^{2}$ area including the grid and $10 \mathrm{~m}$ buffer zone. Length, width, and height of above ground rocks inside the quadrat were calculated to determine above ground rock volume (Laerm et al. 1997). Estimation of herbaceous height (m) was determined as the average height of herbaceous vegetation in the quadrat. An ocular estimate of percent herbaceous vegetative cover also was determined for each quadrat. Herbaceous height and percent cover provided a description of understory vegetative structure at each sampling point. At the Southwest corner of each quadrat, a spherical densiometer was used to measure canopy closure. Depth of leaf litter $(\mathrm{cm})$ was recorded for each corner of the quadrat and averaged.

After the completion of vegetative sampling, grids were randomly assigned to CWD manipulation categories: addition ( $50 \%$ of volume added), removal $(50 \%$ of volume removed), and control (disturbed but not manipulated) (Loeb 1999). Logs were chosen from the landscape surrounding the grid, and distributed throughout the grid and buffer zone. When necessary, larger CWD was cut with a chainsaw and pieced back 
together after being transported to the trapping grid. Each site was re-trapped within 24 hours of the completion of manipulations to test the immediate effect of the disturbance on small mammal capture rates.

Data Analyses

Abundance of small mammals was determined using program CAPTURE and captures per 100 trap nights (CPUE) (White et al. 1982, Rexstad and Burnham 1991). Low sample sizes proved the model selection function in program CAPTURE unrenderable, and I was forced to use the null model for analysis (Rexstad and Burnham 1991). Only Peromyscus spp. provided enough captures to be analyzed with program CAPTURE. Trapping sessions producing no recaptures were dropped from program CAPTURE analysis. Relative abundance of each species was calculated using CPUE with corrections made for sprung traps and recaptures (Nelson and Clarke 1973, Carey and Johnson 1995, Laerm 1997). Total relative abundance of all species combined and individual species representing $2 \%$ or more of total captures were analyzed. Species richness (S), Pielou's Index of evenness (J), Simpson's Diversity index (D), and the Shannon Diversity $(\mathrm{H})$ index were calculated for all small mammals captured in each trapping session (Magurran 1988, Krohne 1998). Ratio of males to females, proportion of reproductive females at each trap site, and mean mass (g) per grid were calculated for each species as measures of habitat quality (Carey and Johnson 1995, Loeb 1999). However, only Peromyscus spp. and northern short-tailed shrew were analyzed in statistical models because of low capture rates of other species. Each value listed above was a dependent variable in the models described below. 
Statistical Analysis System (SAS Institute, Cary, N.C.) was used for all statistical analyses. Trapping grid was the experimental unit for all dependent variables except mass. The individual small mammal was the experimental unit for average mass calculations. A Multivariate Analysis of Variance (MANOVA) was performed on vegetative measurements and the riparian/upland and edge/interior grid locations to test if microhabitat characteristics differed between riparian and upland sites or edge and interior sites. Because all variables were not similar between edge and interior habitats $(\underline{\mathrm{P}}<0.05)$, we included location (edge/interior) and CWD effects but excluded habitat (riparian/upland) $(\underline{\mathrm{P}}>0.05)$ effect from our statistical models involving small mammals. Two split plot models were used to analyze the data sets. The first model (I) included all trapping sessions after manipulations for the original 12 trapping grids. This model includes 6 trapping sessions after manipulations for each of the original 12 grids. The first branch of the split plot included CWD and trapping location. These data were analyzed to compare estimates among addition, removal, and control grids and between edge and interior sites. The interaction term of CWD and trapping location also was included in the first branch of the model. In the second branch of Model I, CWD, trapping location, and associated interactions were tested by trapping session to search for short-term temporal patterns arising from CWD manipulation. Year was not included in model I because all grids were manipulated during the same trapping session in the same year. The second model (II) included the 12 original grids and the 6 grids added in 2001, but only trapping sessions after manipulations from the first year of trapping for each grid were included. There were 2 trapping sessions after manipulations in 2000 for the original 12 grids and 4 trapping sessions after manipulations in 2001 for the 6 new 
grids. This model was identical to model I with the addition of year as a block. Adding year as a block corrects for the grids being manipulated in different years. Data from the session of trapping conducted before manipulations was analyzed in each model to test if any differences occurred among CWD manipulation categories before manipulations. Tukey's Studentized Range Test was used to identify differences among tracts when significant $\underline{F}$ values $(\underline{\alpha}=0.05)$ were obtained. In the event an interaction term of interest produced a significant $\underline{F}$ value $(\underline{\alpha}=0.05)$, the least squares means procedure in SAS, which performs a t-test similar to Fisher's least significant difference test, was used to assess differences between interaction term categories. Assumptions of normality were tested using the univariate procedure in SAS, and a Bartlett's test was used to test homogeneity of variance assumptions. Square-root and quarter-root transformations were used to convert dependent variables that did not meet the aforementioned assumptions (Dowdy and Wearden 1991, Zar 1999).

\section{RESULTS}

Habitat sampling and CWD manipulations

Habitat variables were similar between riparian and upland sites (Wilks' $\underline{\lambda}=0.66$, $\underline{\mathrm{P}}=0.828)$ (Table 2). Basal area was higher in interior than in edge habitats $(\underline{\mathrm{F}}=13.27$, $\mathrm{df}=1,10, \underline{\mathrm{P}}=0.005)$, but no differences were observed in other microhabitat characteristics between edge and interior sites (Wilks' $\underline{\lambda}=0.21, \underline{\mathrm{P}}=0.11$ ). There was no interaction between location (edge/interior) and habitat (riparian/upland) (Wilks' $\underline{\lambda}=$ $0.39, \underline{\mathrm{P}}=0.39)$. The most common tree species in basal area measurements were yellowpoplar (Liriodendron tulipifera) $(32 \%)$, sugar maple (Acer Saccharum) $(12 \%)$, black 
locust (obinia pseudoacacia) $(12 \%)$, and black cherry (Prunus serotina). Mean rock volume varied by grid, ranging from $0 \mathrm{~cm}^{3} /$ ha to $46,490 \mathrm{~cm}^{3} /$ ha, but was similar across CWD manipulation classes (Table 2). The remaining habitat variables were more consistent across grids and CWD classes (Appendix IIa).

Volumes of CWD before manipulations ranged from $11.72 \mathrm{~m}^{3} /$ ha to 145.14 $\mathrm{m}^{3} /$ ha, while volumes after manipulations ranged from $8.86 \mathrm{~m}^{3} /$ ha to $217.71 \mathrm{~m}^{3} / \mathrm{ha}$ (Appendix IIa). Average volume of CWD was similar among addition, removal, and control sites before manipulations $(\underline{F}=0.56, \mathrm{df}=2,12, \underline{\mathrm{P}}=0.583)$. After manipulation of CWD, average volume was higher on addition sites than removal sites, similar between addition and control sites, and similar between removal and control sites $(\underline{F}=3.47, \mathrm{df}=$ $2,12, \underline{\mathrm{P}}=0.037)$.

\section{Small Mammal Populations}

Sherman traps were set for 4,160 potential trap nights and provided 348 individuals of 10 different species in 2000. During the 2001 field season, 8,849 potential trap nights produced 1,216 individuals of 15 different species (Appendix IIb). Overall, 1,564 individuals were captured in 13,009 trap nights on the CDCTA using Sherman live traps. Peromyscus spp. $(\underline{\mathrm{N}}=1,163)$ were the most common species captured representing $74 \%$ of all captures. Other species representing $2 \%$ or more of total captures were northern short-tailed shrew $(\underline{\mathrm{N}}=187,12 \%)$, southern red-backed vole $(\underline{\mathrm{N}}=81,5 \%)$, eastern chipmunk ( $\underline{\text { Tamias }} \underline{\text { striatus }})(\underline{\mathrm{N}}=54,3 \%)$, and southern flying squirrel ( $\underline{\text { Glaucomys volans }})(\underline{\mathrm{N}}=25,2 \%)$. 
Abundance of Peromyscus spp. using program CAPTURE was similar among CWD manipulation categories (Model I: $\underline{\mathrm{F}}=0.04$, df $=2,5, \underline{\mathrm{P}}=0.959$; Model II: $\underline{\mathrm{F}}=$ $0.10, \mathrm{df}=2,8, \underline{\mathrm{P}}=0.907)$ before manipulations. Similar results were obtained after manipulations for abundance of Peromyscus spp. among CWD manipulation classes (Model I: $\underline{F}=0.06, \mathrm{df}=2,29, \underline{\mathrm{P}}=0.94$; Model II: $\underline{\mathrm{F}}=2.33$, df $=2,13, \underline{\mathrm{P}}=0.14$ ) and between edge and interior sites (Model I: $\underline{\mathrm{F}}=0.68, \underline{\mathrm{df}}=1,29, \underline{\mathrm{P}}=0.440$; Model II: $\underline{\mathrm{F}}=$ 0.22, $\mathrm{df}=1,13, \underline{\mathrm{P}}=0.645)($ Fig. 1$)$. There was no interaction between CWD and location (Model I: $\underline{F}=0.54, \mathrm{df}=2,29, \underline{\mathrm{P}}=0.610 ;$ Model II: $\underline{\mathrm{F}}=0.83, \mathrm{df}=2,13, \underline{\mathrm{P}}=0.464), \mathrm{CWD}$ and trapping session (Model I: $\underline{F}=1.05, \mathrm{df}=10,29, \underline{\mathrm{P}}=0.431$; Model II: $\underline{\mathrm{F}}=0.98, \mathrm{df}=$ $6,13, \underline{\mathrm{P}}=0.340)$, or CWD by location by trapping session (Model I: $\underline{\mathrm{F}}=1.72, \mathrm{df}=9,29, \underline{\mathrm{P}}$ $=0.130$; Model II: $\underline{\mathrm{F}}=1.21, \mathrm{df}=4,13, \underline{\mathrm{P}}=0.302)$ (Fig. 2).

Total relative abundance of small mammals (CPU) was similar among manipulation categories before manipulation of CWD (Model I: $\underline{\mathrm{F}}=0.20, \mathrm{df}=2,6, \underline{\mathrm{P}}=$ 0.824; Model II: $\underline{\mathrm{F}}=0.66, \mathrm{df}=2,11, \underline{\mathrm{P}}=0.536)$. After manipulation of $\mathrm{CWD}$, relative abundance also was similar between manipulation categories (Model I: $\underline{F}=0.22, \mathrm{df}=$ 2,30, $\underline{\mathrm{P}}=0.812$; Model II: $\underline{\mathrm{F}}=0.36, \mathrm{df}=2,14, \underline{\mathrm{P}}=0.709)$ and locations (Model I: $\underline{\mathrm{F}}=$ 1.02, $\mathrm{df}=1,30, \underline{\mathrm{P}}=0.351$; Model II: $\underline{\mathrm{F}}=0.75, \mathrm{df}=1,14, \underline{\mathrm{P}}=0.405)$. The interactions of CWD by location (Model I: $\underline{\mathrm{F}}=1.81, \mathrm{df}=2,30, \underline{\mathrm{P}}=0.243$; Model II: $\underline{\mathrm{F}}=0.01$, $\mathrm{df}=2,14$, $\underline{\mathrm{P}}=0.991), \mathrm{CWD}$ by trapping session (Model I: $\underline{\mathrm{F}}=0.91$, $\mathrm{df}=10,30, \underline{\mathrm{P}}=0.533$; Model II: $\underline{F}=1.13$, df $=6,14, \underline{P}=0.396$ ), and CWD by location by trapping session (Model I: $\underline{F}$ $=2.01, \mathrm{df}=10,30, \underline{\mathrm{P}}=0.070$; Model II: $\underline{\mathrm{F}}=0.84, \mathrm{df}=4,14, \underline{\mathrm{P}}=0.520)$ showed no temporal pattern in total CPU (Fig. 3). 
Relative abundance (CPU) of each species analyzed and all diversity indices were similar between CWD manipulation classes before manipulations in model I (Table 2). Similarly, CPU values for each species analyzed and all diversity estimates were equivalent between CWD manipulation classes before manipulations in model II (Table 3).

After manipulation of CWD, CPU values were similar for all species analyzed in Model I except the southern red-backed vole, which displayed a significant interaction between edge and CWD in Model I $(\underline{F}=12.76, \mathrm{df}=2,30, \underline{\mathrm{P}}=0.007)$ (Table 4). The least significance test showed southern red-backed vole abundance was higher in interior removal sites than all other interaction categories (Fig. 4). Relative abundance of all species analyzed was similar between CWD manipulation classes and habitat locations after manipulations in Model II (Table 5). Interaction terms for CWD by location, CWD by trapping session, and CWD by location by trapping session showed no temporal patterns in relative abundance of any species analyzed (Appendix IIc).

Diversity estimates were similar between CWD manipulation classes and grid location after CWD manipulations in Model I with the exception of species richness (Table 4). Average species richness was higher in removal sites than control sites, but similar between removal and addition sites $(\underline{\mathrm{F}}=6.49, \mathrm{df}=2,30, \underline{\mathrm{P}}=0.032)$. Addition and control sites also showed similar species richness in Model I. Species richness, evenness, and diversity were similar among CWD manipulation categories and between grid locations in Model II (Table 5). Average species richness was similar between edge and interior sites in both models (Model I: $\underline{F}=0.80, \mathrm{df}=1,30, \underline{\mathrm{P}}=0.41$; Model II: $\underline{\mathrm{F}}=0.00$, df $=1,14, \underline{\mathrm{P}}=0.97)$. No temporal pattern in species richness was evident in the analysis of 
CWD by trapping session (Fig. 5). Interactions of CWD by trapping location, CWD by trapping session, and CWD by location by trapping session showed no temporal pattern in species richness, evenness, or diversity (Appendix IIc).

Only Peromyscus spp. provided enough captures in the initial trapping session to compare average mass, ratio of males to females, and proportion of reproductive females before manipulations. Model I (Table 6) and Model II (Table 7) produced similar average mass, ratio of males to females, and proportion of reproductive females

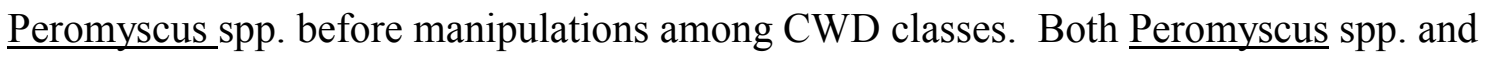
northern short-tailed shrews showed similar mass, ratio of males to females, and proportion of reproductive females among CWD classes and between grid locations after CWD manipulations in Model I (Table 8). Average mass of Peromyscus spp. was higher in removal sites than control sites in Model II after manipulations $(\underline{\mathrm{F}}=4.38, \mathrm{df}=2,395$, $\underline{\mathrm{P}}=0.040$ ) (Table 9). Removal sites and addition sites produced similar mass of

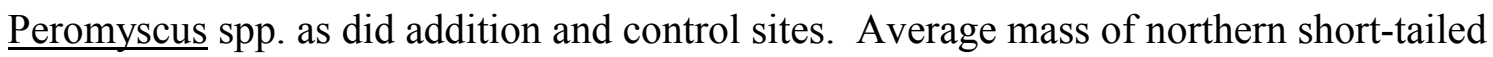
as well as ratio of males to females and proportion of reproductive female Peromyscus spp. and northern short-tailed shrews was similar among CWD manipulation classes and trapping locations in Model II (Table 9). The interaction of CWD by trapping location was not significant for mass, ratio of males to females, or proportion of reproductive females for either species analyzed. In addition, temporal analyses of CWD by trapping session and CWD by location by trapping session showed no pattern in mass, ratio of males to females, or proportion of reproductive females for Peromyscus spp. or northern short-tailed shrews (Appendix IId). 


\section{DISCUSSION}

This study suggests CWD manipulation has little short-term effect on small mammal abundance, diversity, or condition. Average volume of CWD was similar between addition, removal, and control sites before manipulations and predictably different among addition and removal CWD classes after manipulations indicating that volume adjustment did alter the volume of CWD on my study plots. Vegetative characteristics were similar between habitats and grid locations indicating that forest stand characteristics were similar across manipulation classes.

Abundance of small mammals was not related to CWD manipulation type with the exception of southern red-backed voles, which were most abundant in interior removal sites. The species representing the majority of captures (Peromyscus spp. and northern short-tailed shrews) are habitat generalists occurring at high densities in a variety of habitats throughout the Central Appalachian Mountains (Lackey et al. 1985, George et al. 1986, Merritt 1987). Species of the genus Peromyscus generally exhibit less fluctuation in population density among habitats than most other small mammals (Lackey et al. 1985). The ability of these species to adapt to a variety of habitat conditions is the most likely explanation for the absence of a relationship between small mammal abundance and CWD volume. The availability of standing snags and stumps was not measured in this study. These structural features in addition to leaf litter depth, rock volume, and herbaceous cover, none of which differed among CWD manipulation classes, must provide adequate cover for small mammals. These results are consistent with Bowman et al. (2000) who found no relationship between small mammal abundance and mean decay class or overall abundance of logs. Billig and Servello (2002) found 
little evidence of a relationship between CWD and small mammal abundance in mixed deciduous-coniferous forests in Maine. In North Carolina, all species captured except deer mice were poorly correlated with CWD volume across a gradient from wildlife openings to forest interiors (Menzel et al. 1999). However, several studies have provided evidence to contradict these findings. Cotton Mice ( short-tailed shrews, and cotton rats ( $\underline{\text { Sigmodon hispidus }})$ were more abundant in plots with heavy loads of CWD (6.55 logs per $\left.200 \mathrm{~m}^{2}\right)$ than plots that had been cleared of storm blow down (2.04 logs per $200 \mathrm{~m}^{2}$ ) in South Carolina (Loeb 1999). Carey and Johnson (1995) found CWD volume to be an accurate predictor of abundance in deer

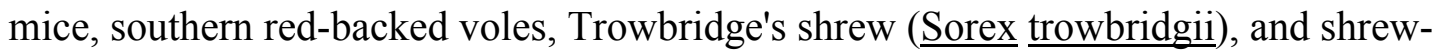
moles (Neurotrichus gibbsii) in Washington. Butts and McComb (2000) found that the probability of encountering Trowbridges's shrew increased as CWD volume increased in western Oregon on sites ranging in CWD volume from 14 to $859 \mathrm{~m}^{3} /$ ha. The volumes on our study plot ranged from $9 \mathrm{~m}^{3} /$ ha to $218 \mathrm{~m}^{3} /$ ha after CWD manipulations. Perhaps conducting a volume manipulation study on experimental plots with a wider initial range of CWD volume would aid in the detection of differences in abundance associated with CWD volume adjustment. However, these volumes are representative of the study area and provide an accurate depiction of forestry in the region.

Species richness was the only diversity measure showing any difference between manipulated grids and control grids, with removal grids producing higher richness values than control grids. These results are somewhat puzzling considering the initial hypothesis was that removal of CWD would cause a decrease in abundance and diversity of small mammals. No temporal pattern in species richness was observed, indicating that 
the decrease in species richness after manipulation was not a steady decline. Few studies have compared diversity measures with changes in CWD volume. Carey and Johnson (1995) found differences in community structure associated with changes in structure of understories in the Pacific Northwest, but diversity changes were not reported. It appears from my results that changes in CWD volume have little effect on the diversity of small mammal communities in Central Appalachian forest environments.

The estimators of small mammal demographics presented in this study provide little evidence of a relationship between CWD and condition of small mammals. Loeb (1999) described higher quality habitat for cotton mice in plots with higher densities of logs. However, Loeb (1999) was unable to make conclusions about any other species because of low captures rates. In addition, no statistical difference was recorded in CWD volume among these plots (Loeb 1999). In Washington, sites with high amounts of CWD $\left(170.07-324.27 \mathrm{~m}^{3} / \mathrm{ha}\right)$ were correlated with higher reproductive rates of Trowbridge's shrew than associated control sites with lower CWD volumes $\left(12.12-45.21 \mathrm{~m}^{3} / \mathrm{ha}\right)($ Lee 1993, 1995). These studies were conducted in forest stands providing much different habitat features for small mammals than Central Appalachian forests, and neither of these species inhabited our study site. Neither of the aforementioned authors found a significant relationship between CWD volume and condition of Peromyscus spp. or northern short-tailed shrews.

It is difficult to make accurate, broadly applicable conclusions on the relationship of small mammals and CWD volume because of varied results observed in different ecological settings (Ford et al. 1997, Menzel et al. 1999, Bowman et al. 2000, Butts and McComb 2000). Though many studies have demonstrated small mammal use of CWD as 
pathways and dens (Nordyke and Buskirk 1991, Barnum et al. 1992, Planz and Kirkland 1992, Tallmon and Mills 1994, McMillan and Kaufman 1995), mixed results exist on the association of small mammal population characteristics and change in CWD volume (Loeb 1999, Menzel et al. 1999). One factor that could have caused an inability to detect temporal patterns in population characteristics in my study was the variability in abundance and diversity of small mammals on control sites. Because control sites provided my baseline of comparison for addition and removal sites, a steadier pattern in abundance and diversity on control grids may have provided a better standard for detection of differences. Another factor that could have prevented me from detecting temporal patterns on manipulated sites is the length of the study. Small mammal abundances were much higher in addition, removal, and control grids in 2001 than 2000 . Fluctuations in small mammal abundance from year to year are common, and a study of this nature may produce different results over a 5-10 year period (Heske 1995, Lee 1995, Krohne 1998, Loeb 1999). However, the overall lack of effect of CWD volume manipulation on small mammal populations was evident across removal and addition grids and across years suggesting little effect of CWD manipulation on small mammal populations.

Based on the results of this study, I recommend land managers need not be concerned with maintaining specific volumes of CWD in Central Appalachian forests to maintain small mammal communities. I did not completely remove CWD from any of the trapping grids sampled in this study, but I did find that sites with CWD loadings as low as $8.86 \mathrm{~m}^{3} /$ ha produced similar small mammal abundance and diversity as sites with significantly greater volumes. However, because small mammals and other vertebrates 
use CWD, further studies of different aspects of CWD use are recommended (Harmon et al. 1986, Loeb 1999, Butts and McComb 2000). The role of decay class, spatial arrangement, species of logs, and other CWD characteristics may be of more importance than simply total volume of CWD on a site. Land managers should make an effort to maintain some level of CWD for small mammals and other vertebrate groups. I recommend a starting point of $8.86 \mathrm{~m}^{3} /$ ha since this was my lowest average CWD volume and I found CWD volume to be a poor predictor of small mammal community and demographic indices. 


\section{LITERATURE CITED}

Avery, T. E., and H. E. Burkhart. 1983. Forest Measurement. McGraw Hill, New York, N.Y. 331pp.

Barnum, S. A., C. J. Manville, J. R. Tester, and W. J. Carmen. 1992. Path selection by

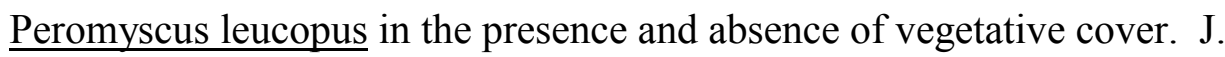
Mamm. 73:797-801.

Barry, R. E., Jr., and E. N. Francq. 1980. Orientation to landmarks within the preferred habitat by Peromyscus leucopus. J. Mamm. 61:292-303.

Bell, J.W. 2001. Soil survey of Camp Dawson, Preston County, West Virginia. U.S.D.A. Natural Resources Conservation Service.

Billig, S. and F. Servello. 2002. Responses of small mammal populations to two recommended forest management practices: retention of woody debris and use of buffer strips. Proc. $58^{\text {th }}$ Annu. Northeast Fish and Wildl. Conf.

Bowman, J. C., D. Sleep, G. J. Forbes, and M. Edwards. 2000. The association of small mammals with coarse woody debris at log and stand scales. For. Ecol. and Manage. 129:119-124.

Butts, S. R., and W. M. McComb. 2000. Associations of forest floor vertebrates with coarse woody debris in managed forests of western Oregon. J. Wildl. Manage. 64:95-104.

Carey, A. B., and M. L. Johnson. 1995. Small mammals in managed, naturally young, and old-growth forests. Ecol. Appl. 5:336-352.

Dowdy, S., and Wearden, S. 1991. Statistics for research. John Wiley and Sons, New York, N.Y. 629 pp. 
Ford, W. M., J. Laerm, and K. G. Baker. 1997. Soricid response to forest stand age in southern Appalachian cove hardwood communities. For. Ecol. and Manage. 91:175-181.

Freedman, B., V. Zelany, D. Beaudette, T. Fleming, S. Flemming, G. Forbes, J. S. Gerrow, G. Johnson, and S. Woodley. 1996. Biodiversity implications of changes in the quantity of dead organic matter in managed forests. Environ. Rev. 4:238-265.

George, S. B., J. R. Choate, and H. H. Genoways. 1986. Blarina brevicauda. Mammalian Species 261:1-9.

Graves, S., J. Maldonado, and J. O. Wolff. 1988. Use of ground and arboreal microhabitats by Peromyscus leucopus and Peromyscus maniculatus. Can. J. Zool. 66:277-278.

Gunderson, H. L. 1959. Red-backed vole habitat studies in central Minnesota. J. Mamm. 40:405-412.

Harmon, M. E., J. F. Franklin, F. J. Swanson, P. Sollins, S. V. Gregory, J. D. Lattin, N. H. Anderson, S. P. Cline, N. G. Aumen, J. R. Sedell, G. W. Lienkaemper, K. Cromack, Jr., and K. W. Cummins. 1986. Ecology of coarse woody debris in temperate ecosystems. Advances in Ecol. Res. 15:133-302.

Hayes, J. P., and S. P. Cross. 1987. Characteristics of logs used by western red-backed voles, $\underline{\text { Clethrionomys californicus, }}$ and deer mice, $\underline{\text { Peromyscus maniculatus. }}$ Can. Field Nat. 101:543-546.

Heske, E. J. 1995. Mammalian abundances on forest-farm edges versus forest interiors in southern Illinois: Is there an edge effect? J. Mamm. 76:562-568. 
Jorgensen, E. E., S. Demarais, S. M. Sell, and S. P. Lerich. 1998. Modeling habitat suitability for small mammals in Chihuahuan desert foothills of New Mexico. J. Wildl. Manage. 62:989-996.

Krohne, D. T. 1998. General ecology. Wadsworth, Belmont, Calif. 722pp.

Lackey, J. A., D. G. Huckaby, and B. G. Ormiston. 1985. Peromyscus leucopus. Mammalian Species 247:1-10.

Laerm, J., M. A. Menzel, D. J. Wolf, and J. R. Welch. 1997. The effect of riparian zones in structuring small mammal communities in the southern Appalachians. Pages 132-145 in J. E. Cook and B. P. Oswald, compilers. Proc. First Biennial North Am. For. Ecol. Workshop. Soc. of Am. For., North Carolina State University, Raleigh, N.C.

Lee, S. D. 1993. Ecological relationships between coarse woody debris and small mammal communities in managed forests of western Washington. Dissertation, University of Washington, Seattle, Wash. $153 \mathrm{pp}$.

- - 1995. Comparison of population characteristics of three species of shrews and the shrew-mole in habitats with different amounts of coarse woody debris. Acta Theriologica 40:415-424.

Loeb, S. C. 1999. Responses of small mammals to coarse woody debris in a southeastern pine forest. J. Mamm. 80:460-471.

Magurran, A. E. 1988. Ecological diversity and its measurement. Princeton University Press, Princeton, N.J. 
McCarthy, B. C. and R. R. Bailey. 1994. Distribution and abundance of coarse woody debris in a managed forest landscape of the central Appalachians. Can. J. For. Res. 24:1371-1329.

McComb, W. C., K. McGarigal, and R. G. Anthony. 1993. Small mammal and amphibian abundance in streamside and upslope habitats of mature Douglas fir stands of western Oregon. Northwest Sci. 67:7-15.

McMillan, B. R., and D. W. Kaufman. 1995. Travel path characteristics of white-footed mice (Peromyscus leucopus). Can. J. Zool. 73:1474-1478.

Menzel, M. A., W. M. Ford, J. Laerm, and D. Krishon. 1999. Forest to wildlife openings: habitat gradient analysis among small mammals in the southern Appalachians. For. Ecol. and Manage. 114:227-232.

Merritt, J. F. 1987. Mammals of Pennsylvania. University of Pittsburgh Press, Pittsburgh, Pa. 408 pp.

Miller, D. H., and L. L. Getz. 1977. Factors influencing local distribution and species diversity of forest small mammals in New England. Can. J. Zool. 55:806-814.

Nelson, L., Jr., and F. W. Clarke. 1973. Correction for sprung traps in catch/effort calculations of trapping results. J. Mamm. 54:295-298.

Nordyke, K. A., and S. W. Buskirk. 1991. Southern red-backed vole, Clethrionomys gapperi, populations in relation to stand succession and old-growth character in the central Rocky Mountains. Can. Field Nat. 105:330-334.

Planz, J. V., and G. L. Kirkland, Jr. 1992. Use of woody ground litter for travel by the white-footed mouse, Peromyscus leucopus. Can. Field Nat. 106:118-121. 
Rexstad, E., and K. Burnham. 1991. User's guide for interactive program CAPTURE. Colorado Cooperative Fish and Wildlife Research Unit, Fort Collins, Cola.

Spies, T. A., and S. P. Cline. 1988. Coarse woody debris in forests and plantations of coastal Oregon. Pages 5-24 in C. Maser, S. P. Cline, K. Cromack, Jr., J. M. Trappe, and E. Hansen, eds. From the forest to the sea: a story of fallen trees. U. S. Dep. of Agric. For. Serv. Gen. Technical Rep. PNW-229:1-53.

Sullivan, D. S., and T. P. Sullivan. 1980. Deer mouse trappability in relation to bait preference. Can. J. Zool. 58:2282-2284.

Tallmon, D. A., and L. S. Mills. 1994. Use of logs within home ranges of California redbacked voles on remnant of forest. J. Mamm. 75:97-101.

Thomas, J. W. 1979. Wildlife habitats in managed forests, the Blue Mountains of Oregon and Washington. U.S. Dep. Ag. For. Serv. Handb. 553, Washington Office, Washington, D.C.

Vanderhorst, J. 2001. Plant community classification and mapping of Camp Dawson Collective Training Area, Preston County, West Virginia. Nongame Wildl. and Nat. Heritage Program, Wildl. Resources Sect., Div. Nat. Resources, Elkins, W. Va. $108 \mathrm{pp}$.

West Virginia Army Reserve National Guard (WVARNG). 2001. Integrated Natural Resources Management Plan. Camp Dawson, Preston County, W. Va.

White, G. C., D. R. Anderson, K. P. Burnham, and D. L. Otis. 1982. Capture-recapture and removal methods for sampling closed populations. LA-8787-NERP, Los Alamos Natl. Lab., Los Alamos, N.M. 235pp. 
Wilson, D. E., and D. M. Reeder, editors. 1993. Mammal Species of the World.

Smithsonian Institution Press, Washington, D. C.

Zar, J. H. 1999. Biostatistical analysis. Fourth edition. Prentice Hall, Upper Saddle River, New Jersey, USA. 
Table 1. Average vegetative characteristics for addition $(\underline{\mathrm{N}}=6)$, removal $(\underline{\mathrm{N}}=6)$ and control $(\underline{\mathrm{N}}=6)$ coarse woody debris $(\mathrm{CWD})$ manipulation grids on the Camp Dawson Collective Training Area in Preston County, West Virginia during 2000 and 2001.

\begin{tabular}{|c|c|c|c|c|c|c|c|c|c|c|c|c|c|c|c|c|}
\hline \multirow{2}{*}{$\begin{array}{c}\text { Treatment } \\
\text { Type }^{\mathrm{a}}\end{array}$} & \multicolumn{2}{|c|}{$\begin{array}{c}\text { CWD Before } \\
\left(\mathrm{m}^{3} / \mathrm{ha}\right)^{b}\end{array}$} & \multicolumn{2}{|c|}{$\begin{array}{l}\text { CWD After } \\
\left(\mathrm{m}^{3} / \mathrm{ha}\right)^{\mathrm{b}}\end{array}$} & \multicolumn{2}{|c|}{$\begin{array}{c}\text { Basal Area } \\
\left(\mathrm{m}^{2} / \mathrm{ha}\right)\end{array}$} & \multicolumn{2}{|c|}{$\begin{array}{l}\text { Rock Volume } \\
\left(\mathrm{cm}^{3}\right)\end{array}$} & \multicolumn{2}{|c|}{$\begin{array}{l}\text { Litter Depth } \\
(\mathrm{cm})\end{array}$} & \multicolumn{2}{|c|}{$\begin{array}{c}\text { \% Canopy } \\
\text { Cover }\end{array}$} & \multicolumn{2}{|c|}{$\begin{array}{c}\% \text { Herb. } \\
\text { Cover }\end{array}$} & \multicolumn{2}{|c|}{$\begin{array}{c}\text { Height Herb. } \\
\text { Cover }(\mathrm{m})\end{array}$} \\
\hline & $\underline{x}$ & $\mathrm{SE}$ & $\underline{\mathrm{x}}$ & SE & $\underline{\mathrm{x}}$ & $\mathrm{SE}$ & $\underline{x}$ & $\mathrm{SE}$ & $\underline{X}$ & SE & $\underline{\mathrm{x}}$ & $\mathrm{SE}$ & $\underline{\mathrm{x}}$ & $\mathrm{SE}$ & $\underline{\mathrm{x}}$ & $\mathrm{SE}$ \\
\hline Addition & 64.71 & 22.67 & 97.07 & 34.01 & 21.04 & 1.91 & 4919 & 1984 & 0.75 & 0.05 & 99.19 & 0.1 & 58.03 & 1.79 & 0.29 & 0.01 \\
\hline Removal & 33.57 & 4.94 & 16.79 & 2.47 & 11.86 & 2.4 & 3674 & 1951 & 1.11 & 0.05 & 96.96 & 0.55 & 58.13 & 1.9 & 0.29 & 0.01 \\
\hline Control & 47.94 & 17.94 & 47.94 & 17.94 & 17.6 & 2.19 & 3775 & 1471 & 0.73 & 0.04 & 98.71 & 0.2 & 59.25 & 1.71 & 0.27 & 0.01 \\
\hline Edge & 46.48 & 11.98 & 50.73 & 17.98 & 14.00 & 1.92 & 3217 & 1180 & 0.89 & 0.04 & 97.66 & 0.35 & 61.87 & 1.47 & 0.32 & 0.01 \\
\hline Interior & 51.57 & 16.73 & 57.93 & 24.94 & 20.37 & 1.76 & 4560 & 1576 & 0.83 & 0.04 & 99.07 & 0.11 & 54.21 & 1.43 & 0.24 & 0.01 \\
\hline Riparian & 47.30 & 13.06 & 52.42 & 19.40 & 15.81 & 2.37 & 3276 & 1091 & 0.66 & 0.03 & 97.61 & 0.39 & 57.96 & 1.60 & 0.30 & 0.01 \\
\hline Upland & 50.19 & 15.09 & 55.45 & 22.68 & 17.85 & 1.90 & 4450 & 1553 & 1.06 & 0.04 & 98.96 & 0.09 & 58.98 & 1.33 & 0.27 & 0.01 \\
\hline
\end{tabular}

${ }^{a}$ Vegetative characteristics for edge $(\underline{N}=10)$ versus interior $(\underline{N}=8)$ and riparian $(\underline{N}=9)$ versus upland $(\underline{N}=9)$ stratifications are included as analyzed in Multivariate Analysis of Variance to determine if these stratifications should be included in statistical models.

${ }^{\mathrm{b}}$ Coarse woody debris volumes are reported before and after manipulation of CWD. 
Table 2. Captures per 100 trap nights for the 5 most abundant species and diversity estimates for small mammals captured in addition $(\underline{\mathrm{N}}=4)$, removal $(\underline{\mathrm{N}}=4)$, and control $(\underline{\mathrm{N}}=4)$ coarse woody debris $(\mathrm{CWD})$ manipulation classes and edge $(\underline{\mathrm{N}}=8)$ and interior $(\underline{\mathrm{N}}=4)$ trapping sites before CWD manipulations on the Camp Dawson Collective Training Area in Preston County, West Virginia during 2000 and 2001. ${ }^{\mathrm{a}}$

\begin{tabular}{|c|c|c|c|c|c|c|c|c|c|c|c|c|c|c|}
\hline \multirow[b]{2}{*}{ Species or Index } & \multicolumn{2}{|c|}{ Addition } & \multicolumn{2}{|c|}{ Removal } & \multicolumn{2}{|c|}{ Control } & \multirow[b]{2}{*}{$\underline{F}_{2,6}$} & \multirow[b]{2}{*}{$\underline{\mathrm{P}}$} & \multicolumn{2}{|c|}{ Edge } & \multicolumn{2}{|c|}{ Interior } & \multirow[b]{2}{*}{$\underline{\mathrm{F}}_{1,6}$} & \multirow[b]{2}{*}{$\underline{\mathrm{P}}$} \\
\hline & $\underline{\mathrm{x}}$ & $\mathrm{SE}$ & $\underline{\mathrm{x}}$ & SE & $\underline{\mathrm{x}}$ & SE & & & $\underline{x}$ & SE & $\underline{x}$ & SE & & \\
\hline Peromyscus spp. & 8.18 & 3.55 & 7.56 & 1.62 & 8.12 & 3.41 & 0.05 & 0.951 & 7.04 & 2.00 & 9.78 & 2.57 & 0.33 & 0.586 \\
\hline northern short-tailed shrew & 0.56 & 0.32 & 0.28 & 0.28 & 0.56 & 0.56 & 0.17 & 0.845 & 0.69 & 0.29 & 0.00 & 0.00 & 1.97 & 0.211 \\
\hline southern red-backed vole & 0.00 & 0.00 & 0.31 & 0.31 & 0.27 & 0.27 & 2.96 & 0.128 & 0.14 & 0.14 & 0.31 & 0.31 & 1.35 & 0.289 \\
\hline Pielou's Index (J) & 0.65 & 0.12 & 0.65 & 0.07 & 0.29 & 0.17 & 1.65 & 0.268 & 0.57 & 0.10 & 0.44 & 0.15 & 0.06 & 0.820 \\
\hline Simpson's Index (D) & 1.50 & 0.14 & 1.40 & 0.08 & 1.22 & 0.14 & 0.79 & 0.497 & 1.43 & 0.09 & 1.25 & 0.10 & 0.52 & 0.496 \\
\hline Shannon Index $(\mathrm{H})$ & 0.51 & 0.10 & 0.45 & 0.05 & 0.27 & 0.17 & 0.73 & 0.521 & 0.46 & 0.09 & 0.31 & 0.11 & 0.35 & 0.578 \\
\hline
\end{tabular}

${ }^{a}$ Data from 6 trapping sessions from the 12 grids manipulated in 2000 were used for this analysis (Model I). 
Table 3. Captures per 100 trap nights for the 5 most abundant species and diversity estimates for small mammals captured in addition $(\underline{\mathrm{N}}=6)$, removal $(\underline{\mathrm{N}}=6)$, and control $(\underline{\mathrm{N}}=6)$ coarse woody debris $(\mathrm{CWD})$ manipulation classes and edge $(\underline{\mathrm{N}}=10)$ and interior $(\underline{\mathrm{N}}=$ 8) trapping sites before CWD manipulations on the Camp Dawson Collective Training Area in Preston County, West Virginia during 2000 and 2001.

\begin{tabular}{|c|c|c|c|c|c|c|c|c|c|c|c|c|c|c|}
\hline \multirow[b]{2}{*}{ Species or Index } & \multicolumn{2}{|c|}{ Addition } & \multicolumn{2}{|c|}{ Removal } & \multicolumn{2}{|c|}{ Control } & \multirow[b]{2}{*}{$\underline{F}_{2,11}$} & \multirow[b]{2}{*}{$\underline{\mathrm{P}}$} & \multicolumn{2}{|c|}{ Edge } & \multicolumn{2}{|c|}{ Interior } & \multirow[b]{2}{*}{$\underline{F}_{1,11}$} & \multirow[b]{2}{*}{$\underline{\mathrm{P}}$} \\
\hline & $\underline{\mathrm{x}}$ & $\mathrm{SE}$ & $\underline{\mathrm{x}}$ & $\mathrm{SE}$ & $\underline{\mathrm{x}}$ & $\mathrm{SE}$ & & & $\underline{\mathrm{x}}$ & $\mathrm{SE}$ & $\underline{\mathrm{x}}$ & $\mathrm{SE}$ & & \\
\hline Peromyscus spp. & 12.59 & 4.42 & 21.25 & 9.25 & 16.25 & 5.64 & 0.90 & 0.435 & 15.27 & 6.00 & 18.48 & 4.32 & 0.93 & 0.355 \\
\hline northern short-tailed shrew & 1.28 & 0.64 & 1.08 & 0.54 & 2.44 & 1.53 & 1.40 & 0.288 & 1.80 & 0.93 & 1.34 & 0.59 & 4.58 & 0.056 \\
\hline southern red-backed vole & 20.9 & 1.88 & 0.65 & 0.29 & 2.03 & 1.34 & 0.48 & 0.630 & 0.53 & 0.30 & 2.93 & 1.56 & 0.54 & 0.477 \\
\hline eastern chipmunk & 0.24 & 0.24 & 0.00 & 0.00 & 0.69 & 0.47 & 1.90 & 0.195 & 0.14 & 0.14 & 0.53 & 0.37 & 0.00 & 0.979 \\
\hline southern flying squirrel & 0.19 & 0.19 & 0.00 & 0.00 & 0.00 & 0.00 & 0.97 & 0.409 & 0.00 & 0.00 & 0.14 & 0.14 & 0.43 & 0.528 \\
\hline Species Richness (S) & 3.33 & 0.71 & 2.50 & 0.34 & 3.00 & 0.86 & 1.32 & 0.306 & 2.60 & 0.43 & 3.38 & 0.65 & 0.13 & 0.721 \\
\hline Pielou's Index (J) & 0.65 & 0.08 & 0.54 & 0.08 & 0.40 & 0.13 & 1.26 & 0.322 & 0.54 & 0.09 & 0.52 & 0.08 & 0.03 & 0.875 \\
\hline Simpson's Index (D) & 1.73 & 0.17 & 1.34 & 0.06 & 1.48 & 0.20 & 2.13 & 0.166 & 1.44 & 0.09 & 1.62 & 0.18 & 0.00 & 0.969 \\
\hline Shannon Index $(\mathrm{H})$ & 0.71 & 0.14 & 0.43 & 0.04 & 0.52 & 0.19 & 1.44 & 0.278 & 0.49 & 0.09 & 0.64 & 0.15 & 0.01 & 0.920 \\
\hline
\end{tabular}

${ }^{\text {a }}$ Data from 2 trapping sessions from the 12 grids manipulated in 2000 and 4 trapping sessions from the 6 grids manipulated in 2001 were used for this analysis (Model II). 
Table 4. Captures per 100 trap nights and diversity estimates for small mammals captured in addition $(\underline{\mathrm{N}}=4)$, removal $(\underline{\mathrm{N}}=4)$, and control $(\underline{\mathrm{N}}=4)$ coarse woody debris $(\mathrm{CWD})$ manipulation classes and edge $(\underline{\mathrm{N}}=8)$ and interior $(\underline{\mathrm{N}}=4)$ trapping sites after $\mathrm{CWD}$ manipulations on the Camp Dawson Collective Training Area in Preston County, West Virginia during 2000 and $2001 .^{a}$

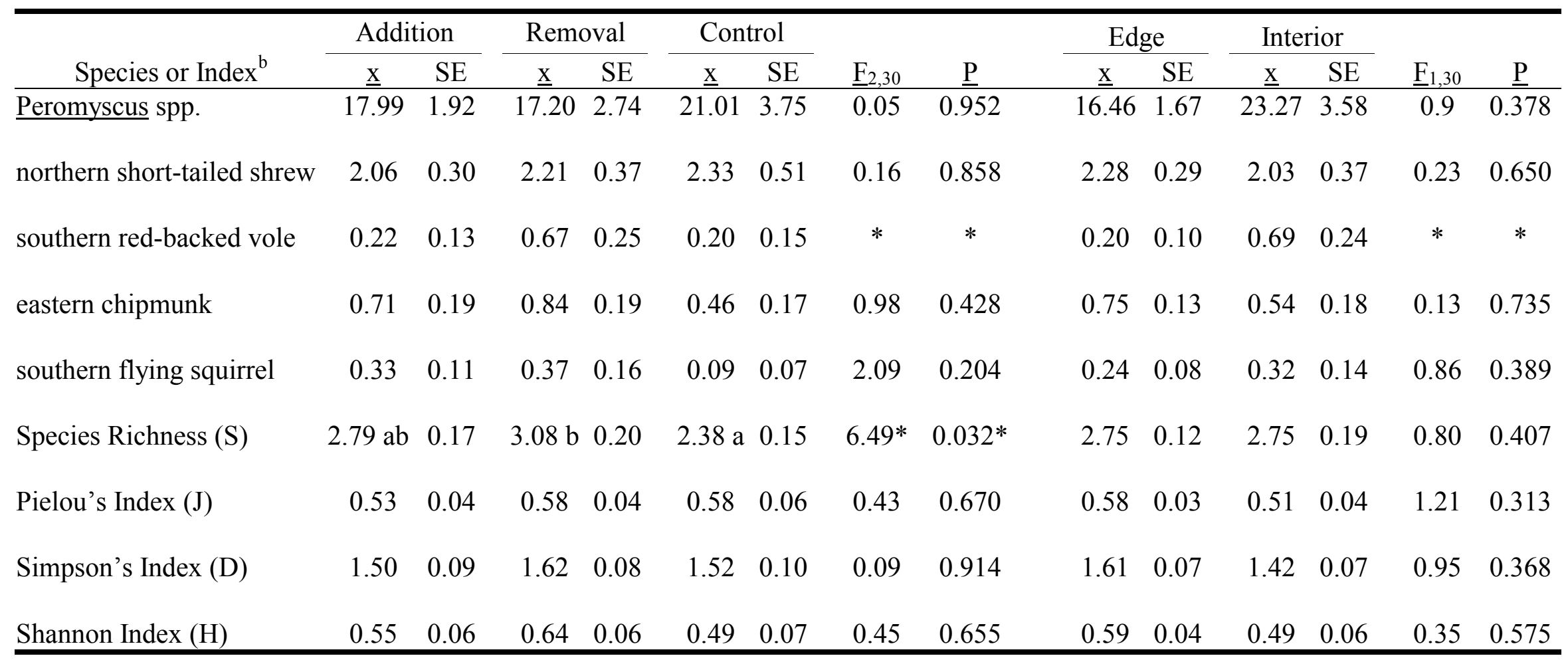

${ }^{a}$ Data from 6 trapping sessions from the 12 grids manipulated in 2000 were used for this analysis (Model I).

${ }^{\mathrm{b}}$ Values with different letters represent statistical differences $(\underline{\mathrm{P}}=0.05)$. 
Table 5. Captures per 100 trap nights for the 5 most abundant species and diversity estimates for small mammals captured in addition $(\underline{\mathrm{N}}=6)$, removal $(\underline{\mathrm{N}}=6)$, and control $(\underline{\mathrm{N}}=6)$ coarse woody debris $(\mathrm{CWD})$ manipulation classes and edge $(\underline{\mathrm{N}}=10)$ and interior $(\underline{\mathrm{N}}=$ 8) trapping sites after CWD manipulations on the Camp Dawson Collective Training Area in Preston County, West Virginia during 2000 and 2001.

\begin{tabular}{|c|c|c|c|c|c|c|c|c|c|c|c|c|c|c|}
\hline \multirow[b]{2}{*}{ Species or Index } & \multicolumn{2}{|c|}{ Addition } & \multicolumn{2}{|c|}{ Removal } & \multicolumn{2}{|c|}{ Control } & \multirow[b]{2}{*}{$F_{2,14}$} & \multirow[b]{2}{*}{$P$} & \multicolumn{2}{|c|}{ Edge } & \multicolumn{2}{|c|}{ Interior } & \multirow[b]{2}{*}{$F_{1,14}$} & \multirow[b]{2}{*}{$P$} \\
\hline & $\underline{x}$ & $\mathrm{SE}$ & $\underline{x}$ & $\mathrm{SE}$ & $\underline{\mathrm{x}}$ & $\mathrm{SE}$ & & & $\underline{x}$ & $\mathrm{SE}$ & $\underline{x}$ & $\mathrm{SE}$ & & \\
\hline Peromyscus spp. & 17.73 & 2.31 & 24.04 & 4.87 & 20.02 & 2.76 & 0.35 & 0.709 & 17.02 & 3.65 & 20.78 & 1.68 & 0.710 & 0.416 \\
\hline northern short-tailed shrew & 1.90 & 0.46 & 1.91 & 0.39 & 2.59 & 0.57 & 0.84 & 0.457 & 1.71 & 0.33 & 2.13 & 0.40 & 1.180 & 0.300 \\
\hline southern red-backed vole & 2.58 & 0.80 & 0.50 & 0.17 & 2.17 & 0.68 & 0.36 & 0.708 & 1.59 & 0.21 & 2.26 & 0.58 & 0.840 & 0.380 \\
\hline eastern chipmunk & 0.66 & 0.24 & 0.90 & 0.31 & 0.76 & 0.29 & 0.17 & 0.843 & 0.92 & 0.30 & 0.58 & 0.18 & 0.010 & 0.942 \\
\hline southern flying squirrel & 0.58 & 0.14 & 0.37 & 0.17 & 0.59 & 0.29 & 0.07 & 0.930 & 0.74 & 0.22 & 0.35 & 0.14 & 0.000 & 0.975 \\
\hline Species Richness (S) & 3.61 & 0.27 & 2.94 & 0.17 & 3.50 & 0.32 & 1.73 & 0.223 & 2.91 & 0.24 & 3.42 & 0.20 & 0.00 & 0.969 \\
\hline Pielou's Index (J) & 0.59 & 0.04 & 0.50 & 0.06 & 0.61 & 0.05 & 0.30 & 0.750 & 0.60 & 0.06 & 0.55 & 0.03 & 0.15 & 0.704 \\
\hline Simpson's Index (D) & 1.78 & 0.11 & 1.49 & 0.10 & 1.71 & 0.10 & 0.36 & 0.708 & 1.71 & 0.11 & 1.57 & 0.06 & 0.84 & 0.379 \\
\hline Shannon Index $(\mathrm{H})$ & 0.77 & 0.07 & 0.52 & 0.07 & 0.71 & 0.07 & 0.94 & 0.420 & 0.63 & 0.07 & 0.66 & 0.05 & 0.41 & 0.534 \\
\hline
\end{tabular}

${ }^{a}$ Data from 2 trapping sessions from the 12 grids manipulated in 2000 and 4 trapping sessions from the 6 grids manipulated in 2001 were used for this analysis (Model II). 
Table 6. Average mass (g), ratio of males to females, and proportion of reproductive females for Peromyscus spp. captured in addition $(\underline{\mathrm{N}}=4)$, removal $(\underline{\mathrm{N}}=4)$, and control $(\underline{\mathrm{N}}=4)$ coarse woody debris $(\mathrm{CWD})$ manipulation classes and edge $(\underline{\mathrm{N}}=8)$ and interior $(\underline{\mathrm{N}}=4)$ trapping sites before CWD manipulations on the Camp Dawson Collective Training Area in Preston County, West Virginia during 2000 and 2001. ${ }^{\text {a }}$

\begin{tabular}{|c|c|c|c|c|c|c|c|c|c|c|c|c|c|c|}
\hline \multirow[b]{3}{*}{ Index ${ }^{\mathrm{b}}$} & \multicolumn{6}{|c|}{ CWD Manipulation Class } & \multirow[b]{3}{*}{$\underline{F}$} & \multirow[b]{3}{*}{$\underline{P}$} & \multicolumn{4}{|c|}{ Location } & \multirow[b]{3}{*}{$\underline{F}$} & \multirow[b]{3}{*}{$\underline{P}$} \\
\hline & \multicolumn{2}{|c|}{ Addition } & \multicolumn{2}{|c|}{ Removal } & \multicolumn{2}{|c|}{ Control } & & & \multicolumn{2}{|c|}{ Edge } & \multicolumn{2}{|c|}{ Interior } & & \\
\hline & $\underline{\mathrm{x}}$ & SE & $\underline{\mathrm{x}}$ & SE & $\underline{\mathrm{x}}$ & $\mathrm{SE}$ & & & $\underline{\mathrm{x}}$ & $\mathrm{SE}$ & $\underline{\mathrm{x}}$ & $\mathrm{SE}$ & & \\
\hline Average mass $(\mathrm{g})$ & 20.77 & 1.05 & 19.48 & 0.70 & 18.4 & 0.58 & 1.24 & 0.299 & 21.29 & 0.68 & 19.53 & 0.86 & 0.28 & 0.599 \\
\hline $\begin{array}{l}\text { Ratio of males to } \\
\text { females }\end{array}$ & 1.34 & 0.39 & 1.70 & 0.51 & 2.28 & 1.40 & 0.88 & 0.633 & 2.03 & 0.71 & 1.96 & 0.47 & 2.59 & 0.243 \\
\hline
\end{tabular}

${ }^{a}$ Data from 6 trapping sessions from the 12 grids manipulated in 2000 were used for this analysis (Model I).

${ }^{b}$ Degrees of freedom for average mass are: CWD - 2, 64; Location - 1, 64. Degrees of freedom for ratio of males to females and proportion of reproductive females are: CWD - 2, 5; Location - 1, 5 . 
Table 7. Average mass (g), ratio of males to females, and proportion of reproductive females for Peromyscus spp. captured in addition $(\underline{\mathrm{N}}=6)$, removal $(\underline{\mathrm{N}}=6)$, and control $(\underline{\mathrm{N}}=6)$ coarse woody debris manipulation classes and edge $(\underline{\mathrm{N}}=10)$ and interior $(\underline{\mathrm{N}}=$ 8) trapping sites before CWD manipulations on the Camp Dawson Collective Training Area in Preston County, West Virginia during 2000 and 2001. ${ }^{\mathrm{a}}$

\begin{tabular}{|c|c|c|c|c|c|c|c|c|c|c|c|c|c|c|}
\hline \multirow[b]{3}{*}{ Index ${ }^{b}$} & \multicolumn{6}{|c|}{ CWD Manipulation Class } & \multirow[b]{3}{*}{$\underline{F}$} & \multirow[b]{3}{*}{$\underline{P}$} & \multicolumn{4}{|c|}{ Location } & \multirow[b]{3}{*}{$\underline{F}$} & \multirow[b]{3}{*}{$\underline{P}$} \\
\hline & \multicolumn{2}{|c|}{ Addition } & \multicolumn{2}{|c|}{ Removal } & \multicolumn{2}{|c|}{ Control } & & & \multicolumn{2}{|c|}{ Edge } & \multicolumn{2}{|c|}{ Interior } & & \\
\hline & $\underline{x}$ & $\mathrm{SE}$ & $\underline{x}$ & $\mathrm{SE}$ & $\underline{x}$ & $\mathrm{SE}$ & & & $\underline{x}$ & $\mathrm{SE}$ & $\underline{x}$ & $\mathrm{SE}$ & & \\
\hline$\overline{\text { Average mass (g) }}$ & 20.51 & 0.82 & 19.33 & 0.58 & 19.52 & 0.44 & 0.86 & 0.432 & 20.15 & 0.47 & 19.13 & 0.53 & 2.72 & 0.101 \\
\hline $\begin{array}{l}\text { Ratio of males to } \\
\text { females }\end{array}$ & 1.51 & 0.30 & 1.57 & 0.34 & 2.37 & 0.96 & 1.08 & 0.378 & 1.77 & 0.57 & 1.80 & 0.25 & 0.04 & 0.846 \\
\hline
\end{tabular}

${ }^{a}$ Data from 2 trapping sessions from the 12 grids manipulated in 2000 and 4 trapping sessions from the 6 grids manipulated in 2001 were used for this analysis (Model II).

${ }^{\mathrm{b}}$ Degrees of freedom for average mass are: CWD - 2, 189; Location - 1, 189. Degrees of freedom for ratio of males to females and proportion of reproductive females are: CWD - 2, 10; Location - 1, 10. 
Table 8. Average mass (g), ratio of males to females, and proportion of reproductive females for Peromyscus spp. and $\underline{\text { Blarina }}$

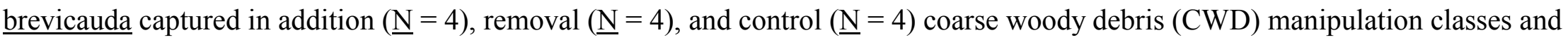
edge $(\underline{\mathrm{N}}=8)$ and interior $(\underline{\mathrm{N}}=4)$ trapping sites after CWD manipulations on the Camp Dawson Collective Training Area in Preston

County, West Virginia during 2000 and 2001. ${ }^{\mathrm{a}}$

\begin{tabular}{|c|c|c|c|c|c|c|c|c|c|c|c|c|c|c|}
\hline \multirow[b]{2}{*}{ Index $^{\mathrm{b}}$} & \multicolumn{2}{|c|}{ Addition } & \multicolumn{2}{|c|}{ Removal } & \multicolumn{2}{|c|}{ Control } & \multirow[b]{2}{*}{$\underline{F}$} & \multirow[b]{2}{*}{$\underline{\mathrm{P}}$} & \multicolumn{2}{|c|}{ Edge } & \multicolumn{2}{|c|}{ Interior } & \multirow[b]{2}{*}{$\underline{F}$} & \multirow[b]{2}{*}{$\underline{\mathrm{P}}$} \\
\hline & $\underline{\mathrm{x}}$ & $\mathrm{SE}$ & $\underline{\mathrm{x}}$ & $\mathrm{SE}$ & $\underline{\mathrm{x}}$ & $\mathrm{SE}$ & & & $\underline{\mathrm{x}}$ & SE & $\underline{\mathrm{x}}$ & $\mathrm{SE}$ & & \\
\hline \multicolumn{15}{|l|}{ Peromyscus spp. } \\
\hline Average mass (g) & 20.51 & 0.25 & 19.26 & 0.31 & 18.74 & 0.25 & 0.00 & 0.996 & 19.95 & 0.22 & 18.84 & 0.22 & 0.25 & 0.633 \\
\hline $\begin{array}{l}\text { Ratio of males to } \\
\text { females }\end{array}$ & 1.25 & 0.14 & 1.06 & 0.10 & 1.52 & 0.29 & 0.53 & 0.614 & 1.12 & 0.09 & 1.58 & 0.28 & 1.32 & 0.294 \\
\hline
\end{tabular}


Table 8. Continued.

\begin{tabular}{|c|c|c|c|c|c|c|c|c|c|c|c|c|c|c|}
\hline \multirow[b]{2}{*}{ Index $^{b}$} & \multicolumn{2}{|c|}{ Addition } & \multicolumn{2}{|c|}{ Removal } & \multicolumn{2}{|c|}{ Control } & \multirow[b]{2}{*}{$\underline{F}$} & \multirow[b]{2}{*}{$\underline{\mathrm{P}}$} & \multicolumn{2}{|c|}{ Edge } & \multicolumn{2}{|c|}{ Interior } & \multirow[b]{2}{*}{$\underline{F}$} & \multirow[b]{2}{*}{$\underline{\mathrm{P}}$} \\
\hline & $\underline{\mathrm{x}}$ & $\mathrm{SE}$ & $\underline{\mathrm{x}}$ & $\mathrm{SE}$ & $\underline{\mathrm{x}}$ & $\mathrm{SE}$ & & & $\underline{\mathrm{x}}$ & SE & $\underline{\mathrm{x}}$ & $\mathrm{SE}$ & & \\
\hline \multicolumn{15}{|l|}{ Blarina brevicauda } \\
\hline Average mass (g) & 15.99 & 0.45 & 16.54 & 0.51 & 15.91 & 0.46 & 0.30 & 0.749 & 16.27 & 0.33 & 15.83 & 0.50 & 0.04 & 0.851 \\
\hline $\begin{array}{l}\text { Ratio of males to } \\
\text { females }\end{array}$ & 0.44 & 0.15 & 0.44 & 0.15 & 0.48 & 0.16 & 0.76 & 0.508 & 0.35 & 0.10 & 0.28 & 0.11 & 2.18 & 0.190 \\
\hline
\end{tabular}

${ }^{a}$ Data from 6 trapping sessions from the 12 grids manipulated in 2000 were used for this analysis (Model I).

${ }^{\mathrm{b}}$ Degrees of freedom for average mass comparisons are: Peromyscus spp. (CWD: $\mathrm{df}=2,573$; E/I: df = 1,573), B. brevicauda (CWD: $\mathrm{df}=2,77 ; \mathrm{E} / \mathrm{I}: \mathrm{df}=1,77)$. Degrees of freedom for ratio of males to females and proportion of reproductive females are: Peromyscus spp. (CWD: $\mathrm{df}=2,71 ; \mathrm{E} / \mathrm{I}: \mathrm{df}=1,71)$, B. brevicauda (CWD: $\mathrm{df}=2,13 ; \mathrm{E} / \mathrm{I}: \mathrm{df}=1,13)$. 
Table 9. Average mass (g), ratio of males to females, and proportion of reproductive females for Peromyscus spp. and northern short-

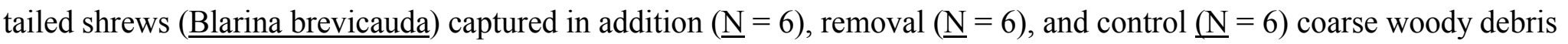
manipulation classes and edge $(\underline{\mathrm{N}}=10)$ and interior $(\underline{\mathrm{N}}=8)$ trapping sites after CWD manipulations on the Camp Dawson Collective Training Area in Preston County, West Virginia during 2000 and 2001. ${ }^{\text {a }}$

\begin{tabular}{|c|c|c|c|c|c|c|c|c|c|c|c|c|c|c|}
\hline \multirow[b]{2}{*}{ Index ${ }^{b c}$} & \multicolumn{2}{|c|}{ Addition } & \multicolumn{2}{|c|}{ Removal } & \multicolumn{2}{|c|}{ Control } & \multirow[b]{2}{*}{$\underline{\mathrm{F}}$} & \multirow[b]{2}{*}{$\underline{\mathrm{P}}$} & \multicolumn{2}{|c|}{ Edge } & \multicolumn{2}{|c|}{ Interior } & \multirow[b]{2}{*}{$\underline{F}$} & \multirow[b]{2}{*}{$\underline{P}$} \\
\hline & $\underline{\mathrm{x}}$ & SE & $\underline{x}$ & SE & $\underline{\mathrm{x}}$ & SE & & & $\underline{\mathrm{x}}$ & SE & $\underline{\mathrm{x}}$ & SE & & \\
\hline \multicolumn{15}{|l|}{ Peromyscus spp. } \\
\hline Average mass (g) & $18.58 \mathrm{ab}$ & 0.29 & $20.03 \mathrm{a}$ & 0.36 & $18.46 \mathrm{~b}$ & 0.37 & $4.38 *$ & $0.040 *$ & 19.32 & 0.29 & 18.84 & 0.27 & 0.09 & 0.770 \\
\hline $\begin{array}{l}\text { Ratio of males to } \\
\text { females }\end{array}$ & 1.25 & 0.19 & 1.09 & 0.12 & 1.06 & 0.15 & 0.40 & 0.677 & 1.18 & 0.15 & 1.09 & 0.10 & 0.08 & 0.787 \\
\hline
\end{tabular}


Table 9. Continued.

\begin{tabular}{|c|c|c|c|c|c|c|c|c|c|c|c|c|c|c|}
\hline \multirow[b]{2}{*}{ Index $^{\text {bc }}$} & \multicolumn{2}{|c|}{ Addition } & \multicolumn{2}{|c|}{ Removal } & \multicolumn{2}{|c|}{ Control } & \multirow[b]{2}{*}{$\underline{F}$} & \multirow[b]{2}{*}{$\underline{P}$} & \multicolumn{2}{|c|}{ Edge } & \multicolumn{2}{|c|}{ Interior } & \multirow[b]{2}{*}{$\underline{\mathrm{F}}$} & \multirow[b]{2}{*}{$\underline{\mathrm{P}}$} \\
\hline & $\underline{\mathrm{x}}$ & SE & $\underline{\mathrm{x}}$ & SE & $\underline{\mathrm{x}}$ & SE & & & $\underline{\mathrm{x}}$ & SE & $\underline{\mathrm{x}}$ & SE & & \\
\hline \multicolumn{15}{|l|}{ Blarina brevicauda } \\
\hline Average mass (g) & 15.20 & 0.53 & 15.40 & 0.70 & 14.96 & 0.44 & 0.15 & 0.862 & 15.45 & 0.50 & 14.96 & 0.40 & 0.02 & 0.885 \\
\hline $\begin{array}{l}\text { Ratio of males to } \\
\text { females }\end{array}$ & 0.23 & 0.12 & 0.36 & 0.20 & 0.36 & 0.17 & 0.10 & 0.908 & 0.40 & 0.19 & 0.26 & 0.09 & 0.67 & 0.438 \\
\hline
\end{tabular}

${ }^{a}$ Data from 2 trapping sessions from the 12 grids manipulated in 2000 and 4 trapping sessions from the 6 grids manipulated in 2001 were used for this analysis (Model II).

${ }^{\mathrm{b}}$ Degrees of freedom for average mass comparisons are as follows: Peromyscus spp. (CWD: $\left.\mathrm{df}=2,395 ; \mathrm{E} / \mathrm{I}: \mathrm{d} . \mathrm{f} .=1,395\right)$, $\underline{\mathrm{B}}$. brevicauda (CWD: $\mathrm{df}=2,43 ; \mathrm{E} / \mathrm{I}: \mathrm{df}=1,43)$. Degrees of freedom for ratio of males to females and proportion of reproductive females are: Peromyscus spp. (CWD: $\mathrm{df}=2,14 ; \mathrm{E} / \mathrm{I}: \mathrm{df}=1,14)$, B. brevicauda (CWD: $\mathrm{df}=2,5 ; \mathrm{E} / \mathrm{I}: \mathrm{df}=1,5)$. Values with different letters represent statistical differences $(\alpha=0.05)$.

${ }^{\mathrm{c}}$ Values with different letters represent statistical differences $(\underline{\mathrm{P}}=0.05)$. 


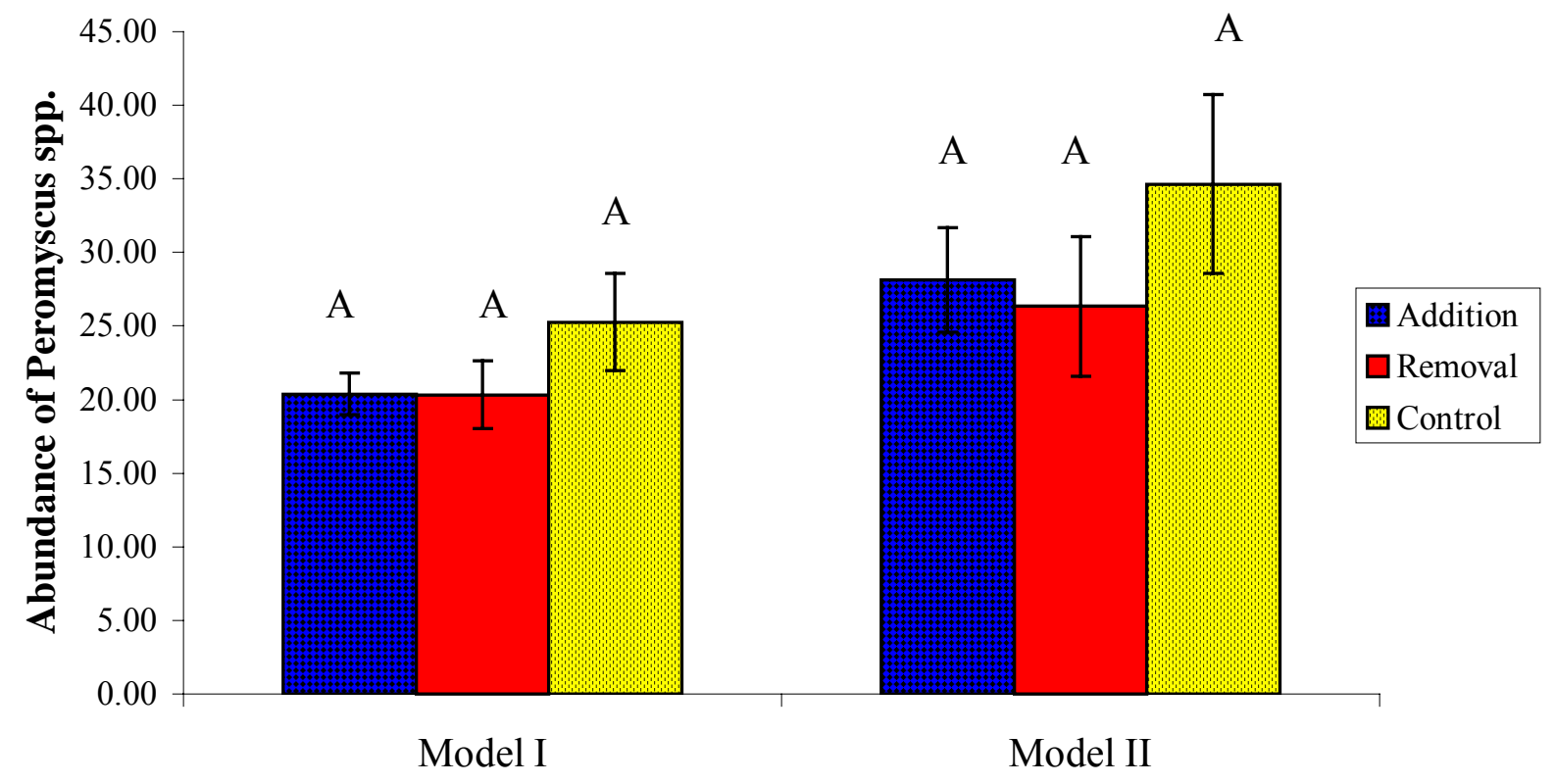

Figure 1. Abundance of Peromyscus spp. on addition, removal and control coarse woody debris manipulation sites in 2 statistical models on the Camp Dawson Collective Training Area in Preston County, West Virginia during 2000 and 2001. Data from 6 trapping sessions from the 12 grids manipulated in 2000 were used for analysis in Model I, and data from 2 trapping sessions from the 12 grids manipulated in 2000 and 4 trapping sessions from the 6 grids manipulated in 2001 were used for analysis in Model II. The same letter above standard error bars indicate no difference for that model $(\underline{\mathrm{P}}>0.05)$. 


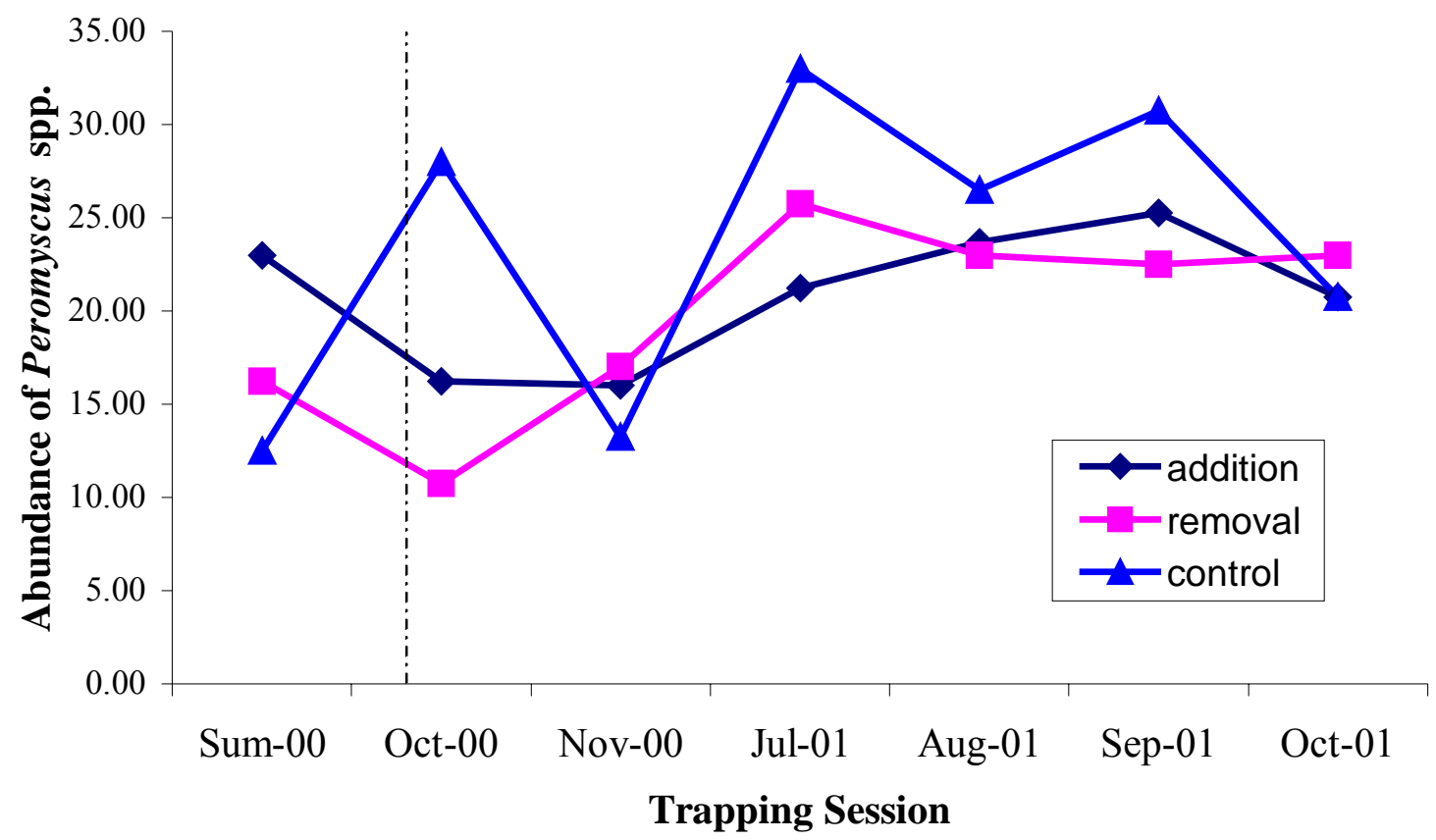

Figure 2. Abundance of Peromyscus spp. by trapping session in addition $(\underline{\mathrm{N}}=4)$, removal $(\underline{\mathrm{N}}=4)$, and control $(\underline{\mathrm{N}}=4)$ coarse woody debris manipulation classes on the Camp Dawson Collective Training Area in Preston County, West Virginia. Trapping session 1 was conducted before manipulations in the summer of 2000 . The line represents the trapping session conducted within 24 hours of manipulations. The other 5 trapping sessions were conducted after manipulations. 


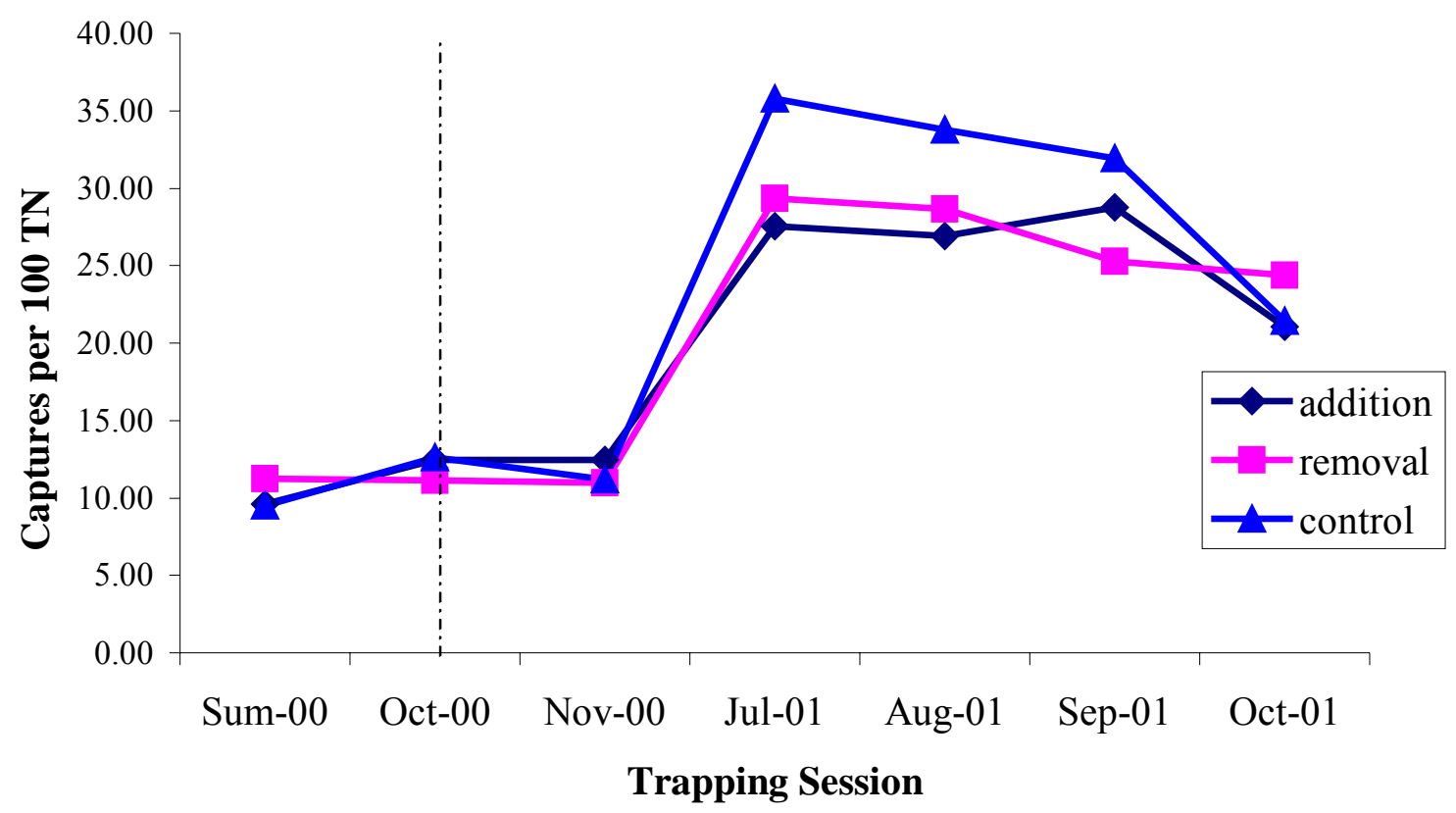

Figure 3. Captures per 100 trap nights $(\mathrm{TN})$ by trapping session in addition $(\underline{\mathrm{N}}=4)$, removal $(\underline{\mathrm{N}}=4)$, and control $(\underline{\mathrm{N}}=4)$ coarse woody debris manipulation classes on the Camp Dawson Collective Training Area in Preston County, West Virginia. Trapping session 1 was conducted before manipulations in the summer of 2000 . The line represents the trapping session conducted within 24 hours of manipulations. The other 5 trapping sessions were conducted after manipulations. 


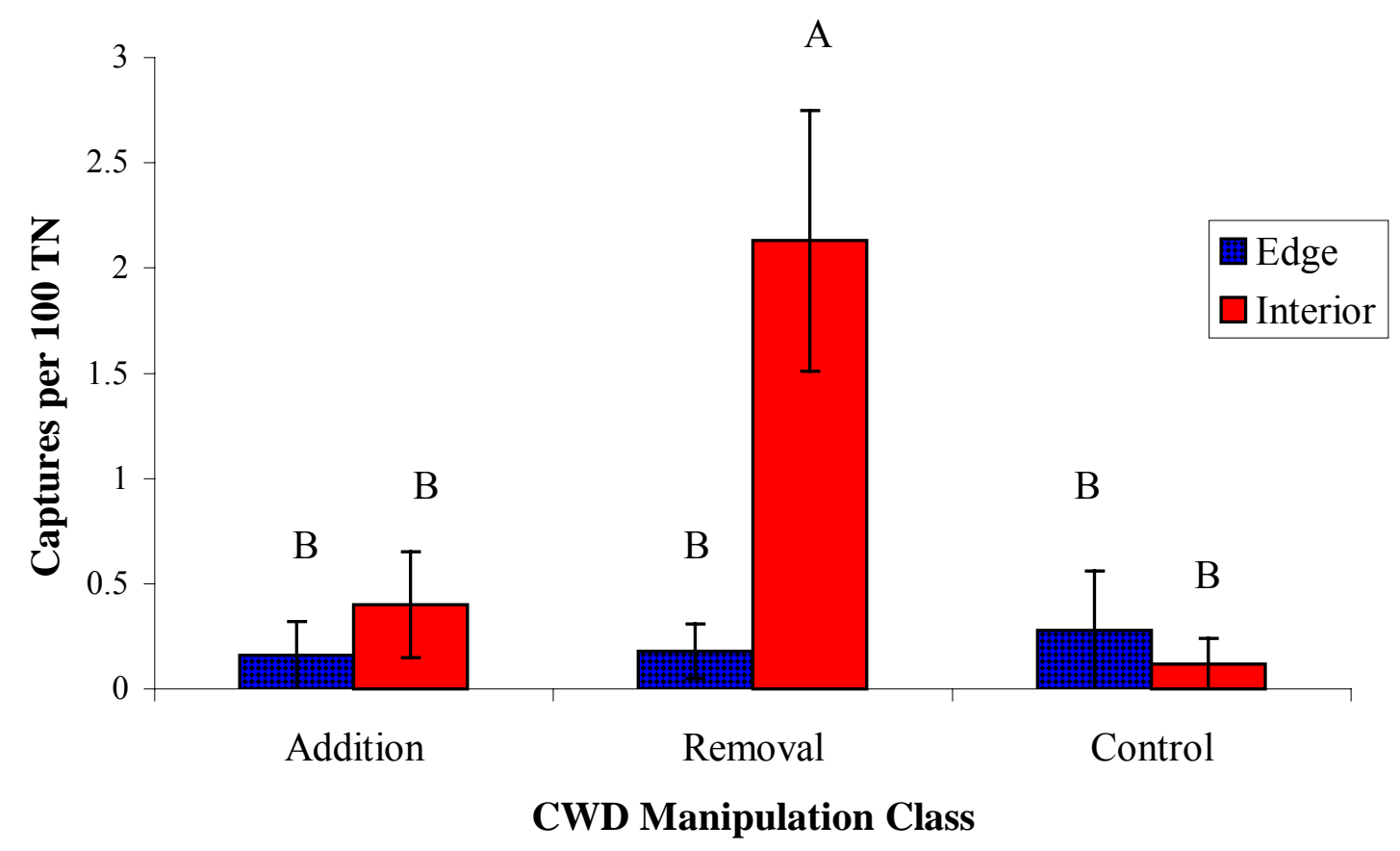

Figure 4. Relative abundance of Southern Red-backed Vole (lethrionomys gapperi) in addition, removal and control coarse woody debris (CWD) manipulation classes of edge and interior forest trapping sites on the Camp Dawson Collective Training Area in Preston County, West Virginia during 2000 and 2001. Different letters above standard error bars indicate different values $(\underline{\mathrm{P}}<0.05)$. 


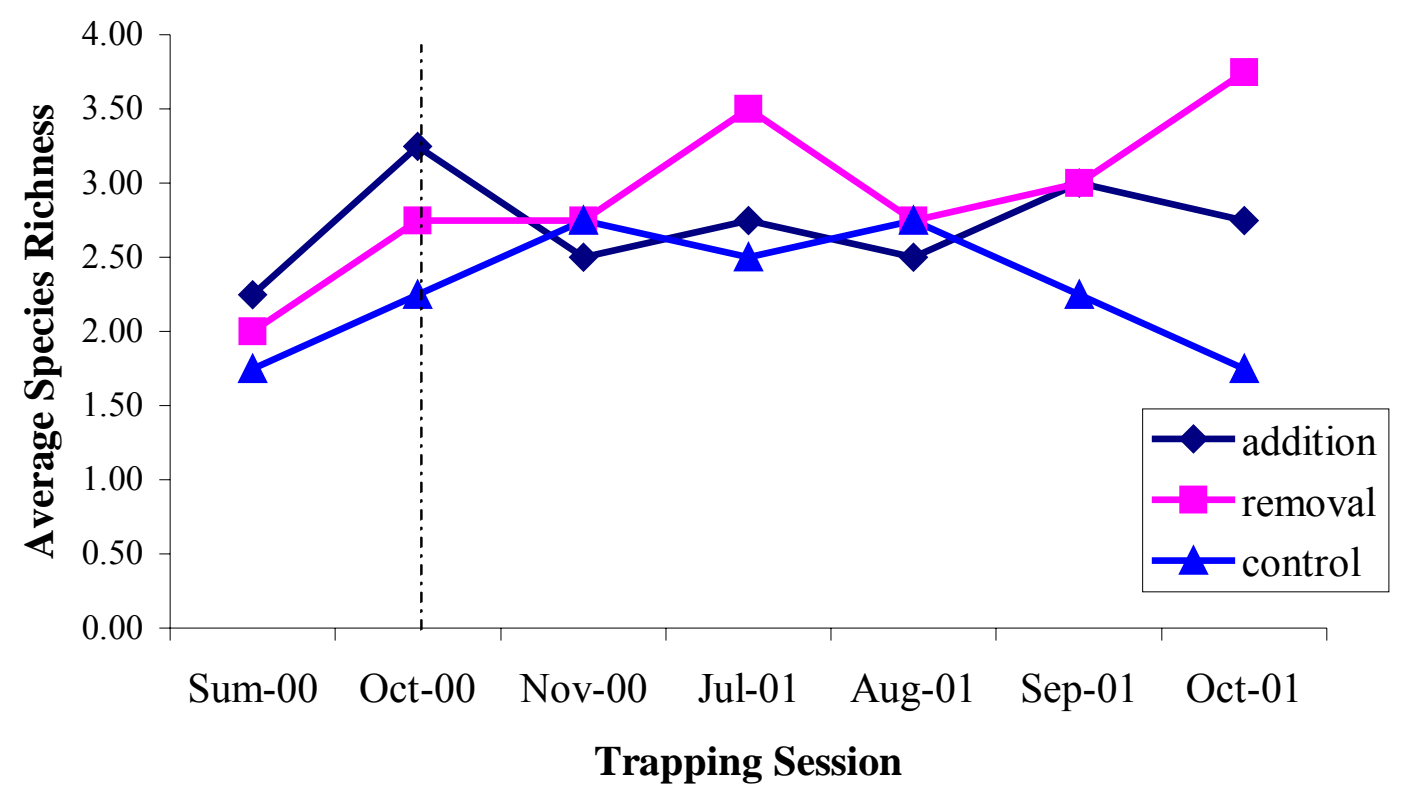

Figure 5. Average species richness by trapping session in addition $(\underline{\mathrm{N}}=4)$, removal $(\underline{\mathrm{N}}=$ 4), and control $(\underline{N}=4)$ coarse woody debris manipulation classes on the Camp Dawson Collective Training Area in Preston County, West Virginia. Trapping session 1 was conducted before manipulations in the summer of 2000. The line represents the trapping session conducted within 24 hours of manipulations. The other 5 trapping sessions were conducted after manipulations. 


\section{CHAPTER III}

\section{EFFECT OF EDGE ON SMALL MAMMAL COMMUNITIES IN RIPARIAN}

\section{AND UPLAND HABITATS}

Abstract: Research on the importance of riparian habitat to small mammals has produced mixed results. In addition, studies have produced varied results when comparing small mammal communities in edge and interior locations. Relative abundance, diversity, and condition of small mammals from pitfall traps were analyzed to test differences between riparian $(<100 \mathrm{~m}$ from water source) and upland ( $\geq 100 \mathrm{~m}$ from water source) habitats in edge ( $<100 \mathrm{~m}$ from habitat edge) and interior ( $\geq 100 \mathrm{~m}$ from habitat edge) locations in northern West Virginia. Shannon diversity was higher in riparian $(\bar{x}=1.79, \mathrm{SE}=0.04)$ than upland $(\bar{x}=1.62, \mathrm{SE}=0.05)$ trapping sites $(P=0.024)$ and also was higher in edge $(\bar{x}=1.74, \mathrm{SE}=0.05)$ than interior $(\bar{x}=1.61, \mathrm{SE}=0.06)$ habitats $(P=0.050)$. Species richness was higher in riparian $(\bar{x}=9.71, \mathrm{SE}=0.31)$ than upland $(\bar{x}=8.71, \mathrm{SE}=0.35)$ trapping locations $(P=0.038)$. Masked shrew (Sorex cinereus) was more abundant in edge $(\bar{x}=4.30, \mathrm{SE}=0.60)$ than interior $(\bar{x}=2.68, \mathrm{SE}=0.41)$ trapping arrays $(P=$ 0.035), while meadow voles (Microtus pennsylvanicus) $(P=0.012)$ and southern bog lemmings (Synaptomys cooperi) $(P=0.001)$ were more abundant in edge than interior sites. Meadow voles $(P=0.021)$ and southern red-backed voles (Clethrionomys gapperi) $(P=0.042)$ were more abundant in upland than riparian habitats. These results suggest that riparian and upland habitats are important in maintaining the highest diversity and healthiest populations of small mammals. Edge habitats should be maintained and enhanced to promote diverse small mammal communities.

JOURNAL OF WILDLIFE MANAGEMENT 00(0):000-000

This chapter written in the style of the Journal of Wildlife Management. 
Key Words: Appalachian, edge, interior, masked shrew, Peromyscus spp., pitfall, riparian, small mammal, trapping, upland

The role of riparian habitat in structuring vertebrate communities has become an important wildlife management issue in human-impacted environments (Knopf et al. 1988, McComb et al. 1993, Thurmond and Miller 1994, Laerm et al. 1997). Many riparian studies have focused on vertebrate groups such as birds and amphibians rather than mammals (Dickson et al. 1995, Thurmond et al. 1995, Whitaker and Montevechhi 1997, Kilgo et al. 1998, Wilkins and Peterson 2000). The value of riparian habitat in maintaining diversity and abundance of small mammals has been documented for some regions (Geier and Best 1980, Doyle 1990, McComb et al. 1993, Thurmond and Miller 1994). However, in the central and southern Appalachians, studies of the relationship between riparian areas and small mammal community structure have produced varied results (Laerm et al. 1997, Ford and Rodrigue 2001). Most studies on small mammalriparian associations have been conducted in pacific northern forests, arid desert regions of the western United States, and southern pine forests (Johnson and Lowe 1985, Doyle 1990, McComb et al. 1993, Thurmond and Miller 1994). Extrapolating the results of studies conducted in the western and southeastern United States in habitat types differing in environmental setting, climate, and species assemblage to central Appalachian forest environments could lead to errant assumptions (Laerm et al. 1997). In addition to the role of riparian zones in the conservation of small mammal community structure, it is important to consider whether riparian zones influence the effective monitoring of small mammal species. If small mammal communities differ between riparian and upland environments in the central Appalachians, monitoring protocols should include sampling 
of both riparian and upland habitats to accurately describe the small mammals assemblages of a region (Laerm et al. 1997, Ford and Rodrigue 2001).

Roads are an obvious necessity for the access and use of land by humans. The quantity and distribution of roads in an area leads to questions of the impact of roads on ecological systems (Richardson et al. 1997, Clevenger and Waltho 2000, Viles and Rosier 2001). Most existing literature associating small mammals and roadways have investigated the effect of roads on small mammal movements (Oxley et al. 1974, Merriam et al. 1989, Richardson et al. 1997, Clark et al. 2001). Fewer studies have investigated small mammal abundance and diversity in roadside versus forest or grassland interior plots (Adams and Geis 1983).

Forest edge has been considered a major factor influencing the structure of biological communities for decades. Leopold (1933) first introduced the concept of edge effects and their influence on the distribution and abundance of some game species. Edge habitat has been described as beneficial to game species, because, within certain limitations, edges often promote higher vegetative diversity and juxtaposition of habitat types for cover, escape, and foraging (Leopold 1933, Yoakum and Dasmann 1969, Pasitschniak-Arts and Messier 1998, Lidicker 1999). Increased habitat fragmentation associated with anthropogenic land uses such as agriculture, urbanization, resource management, and military activity has produced the need for research regarding the effect of human-induced edge on biological diversity (Harris 1988, Heske 1995, Coolinge 1996, Nupp and Swihart 2000). The bulk of research in fragmentation effects has focused on interior species abundances and nest predation/parasitism of songbirds on forest edges (Gates and Geysel 1978, Moller 1989, Pulliam et al. 1992). However, few studies have 
investigated the relationship between small mammal populations and habitat edges in the central Appalachians (Menzel et al. 1999).

Several studies suggested that diversity and abundance measures of small mammals vary according to distance from forest edge (Sekgororoane and Dilworth 1995, Stevens and Husband 1998, Menzel et al. 1999, Nupp and Swihart 2000). However, others have produced results that suggest no significant relationship exists between small mammal communities and distance to forest edge (Heske 1995, Bayne and Hobson 1998). To properly monitor and conserve small mammal populations in the central Appalachians, information is needed on the relationship between habitat edges and small mammal populations (Lidicker 1999). The objectives of this study were to compare abundance, diversity, and condition of small mammal communities between edge and interior forested scrub-shrub habitats and between riparian and upland habitats in northern West Virginia.

\section{STUDY AREA}

This study was conducted on the Camp Dawson Collective Training Area (CDCTA) in Preston County, West Virginia. The CDCTA encompasses 1,665 ha and is comprised of 3 tracts of land: The Cantonment Area (378 ha), the Briery Mountain Training Area (TA) (423 ha), and the Pringle TA (854 ha). All 3 tracts are within 3 km of each other and centered on $39^{\circ} 26^{\prime}$ north latitude and $79^{\circ} 40^{\prime}$ west longitude in the Cheat River Basin. The CDCTA is primarily used for military training by the West Virginia Army Reserve National Guard (WVARNG) and public recreation (WVARNG 2001). 
The primary cover types on the CDCTA are mixed mesophytic forest, mixed montane hardwood forest, successional forest of low elevation plains, old field, and developed areas (Vanderhorst 2001). The primary soils on the study area are loams, silt loams, and rubbly complexes (Bell 2001) (Chapter I).

\section{METHODS}

\section{Trapping}

I collected small mammals from 2 pitfall trap designs targeted at capturing herpetofauna (Bury and Corn 1987, Mengak and Guynn 1987, Greenberg et al. 1994, Spurgeon 2002). The first was a 5-bucket cross-shaped design with a $19 \mathrm{~L}$ bucket in the center and at each end point of the fence (full array). The second design was a straight fence with 1 bucket on each side of each end for a total of 4 buckets per array (transect array). Each fence for both array types consisted of $7.5 \mathrm{~m}$ of silt fence staked and buried 3-4 $\mathrm{cm}$ in the ground.

I determined site locations for pitfall arrays by classifying areas as upland or riparian and edge or interior. I classified riparian sites as $<100 \mathrm{~m}$ from a permanent water body and upland sites as $\geq 100 \mathrm{~m}$ from any type of permanent water source (Laerm et al. 1997). I further stratified by distance to road or forest edge, where edge sites were $<100$ $\mathrm{m}$ from a road or forest edge, and interior sites were located $\geq 100 \mathrm{~m}$ from the road or forest edge. Therefore, I identified each pitfall trapping array as riparian edge (RE), riparian interior (RI), upland edge (UE), or upland interior (UI).

During the first year of trapping (2000), I established 23 arrays with a distribution among treatments of 6 in RE, 2 in RI, 7 in UE, and 8 in UI. During the 2001 trapping season I added 17 new grids for a total of 40 grids and a distribution among treatments of 
8 in RE, 5 in RI, 13 in UE, and 14 in UI. Thus, I designated 13 arrays as riparian and 27 as upland, with 21 of those arrays on edges and 19 at interior sites. I evenly distributed full arrays among riparian (10) and upland (10) habitats with a distribution of 6 in RE, 4 in RI, 5 in UE, and 5 in UI. I evenly split transect arrays among edge (10) and interior (10) trapping locations with a distribution of 2 in RE, 1 in RI, 8 in UE, and 9 in UI.

During the 2000 trapping season pitfalls were open from 5 July 2000 to 27 October 2000. In 2001, pitfall traps were open from 6 April 2001 to 29 October 2001. Pitfall arrays were in continual operation and were generally checked every $24 \mathrm{hrs}$. About $2 \mathrm{~cm}$ of water was placed in the bottom of each bucket to prevent desiccation of amphibians and hasten mammal mortality. All small mammal captures were frozen and later analyzed to determine species, mass (g), sex, and reproductive condition.

\section{Data Analyses}

I calculated relative abundance of small mammals using captures per 100 trap nights (CPU) for each pitfall array (White et al. 1982, Bury and Corn 1987, Sekgororoane and Dilworth 1995). I compared relative abundance values among treatment types for species representing $1 \%$ of all captures and total CPU. I collectively analyzed Whitefooted mice (Peromyscus leucopus) and deer mice (P. maniculatus) as Peromyscus spp. to eliminate bias associated with identification of these species. I calculated species richness (S), Pielou's evenness index (J), and Shannon diversity $(\mathrm{H})$ for each pitfall array using a natural log for the Pielou and Shannon indices (Pielou 1966, Magurran 1988, Krohne 1998). I chose the Shannon diversity index because it gives heavier weight to rare species than common species, which is important when comparing between habitat types (Sekgororoane and Dilworth 1995, Krohne 1998). I calculated ratio of males to 
females per array, proportion of reproductive females at each array, and mean mass (g) per individual per array as measures of condition for each of the 5 most abundant species captured. Each value listed above was a dependent variable analyzed in the statistical model described below.

I used Statistical Analysis System for all statistical analyses (SAS Institute, Cary, North Carolina). I compared abundance, diversity, and condition of small mammals in riparian versus upland and edge versus interior trapping sites with a completely randomized block design Analysis of Variance (ANOVA). The individual pitfall array was the experimental unit about which all dependent variables except mass were averaged. For average mass calculations the individual animal was the experimental unit. The independent variables in the ANOVA model were habitat (riparian and upland), location (edge and interior), and the interaction term between habitat and location. Because I was not concerned with differences in tract of land or year of sampling, tract and year were considered blocks in the ANOVA model (Chapter I). In the event an interaction term produced a significant $F$-value ( $\alpha=0.05$ ), I used the least squares means procedure in SAS to assess differences between RE, RI, UE, and UI trapping locations for the associated variable (Dowdy and Wearden 1991, Zar 1999). I tested assumptions of normality with the univariate procedure in SAS. I used Bartlett's test for homogeneity of variance assumptions. I used square-root and quarter-root transformations to convert dependent variables that did not meet the aforementioned assumptions (Dowdy and Wearden 1991, Zar 1999). 


\section{RESULTS}

Pitfall trapping provided 1,232 individuals of 16 species in 12,972 trap nights in 2000, and 3,316 individuals of 19 different species in 40,794 trap nights in 2001. Thus, pitfall trapping provided 4,548 individuals of 21 small mammal species in 53,766 trap nights during the course of this study (Appendix IIIa). I captured 1,666 small mammals in riparian habitats and 2,882 in upland areas. Edge locations provided 2,235 captures while interior sites produced 2,313 individuals. The distribution of captures among interaction groups was 949 in RE, 717 in RI, 1,286 in UE, and 1,596 in UI. There were 11 species or species groups that each represented $1 \%$ or more of the total number of captures: masked shrew (Sorex cinereus) $(n=1,502,33 \%)$, Peromyscus spp. $(n=773,17$ $\%$ ), smoky shrew (Sorex fumeus) $(n=537,11 \%)$, northern short-tailed shrew (Blarina brevicauda) $(n=504,11 \%)$, woodland jumping mouse (Napaeozapus insignis) $(n=473$, $10 \%$ ), meadow jumping mouse (Zapus hudsonius) $(n=413,9 \%)$, meadow vole (Microtus pennsylvanicus) $(n=210,5 \%)$, southern red-backed vole (Clethrionomys gapperi) $(n=118,3 \%)$, southern bog lemming (Synaptomys cooperi) $(n=64,1 \%)$, eastern chipmunk (Tamias striatus) $(n=46,1 \%)$, and long-tailed shrew (Sorex dispar) $(n$ $=26,1 \%)$.

Mean CPU values for all small mammals combined were similar between locations $\left(F_{1,56}=2.00, P=0.163\right)$ and habitat types $\left(F_{1,56}=3.14, P=0.082\right)($ Table 1$)$. The interaction of habitat and location also was not significant $\left(F_{1,56}=0.03, P=0.863\right)$. The similarity in overall CPU between treatment types was not reflected in the comparisons of mean CPU for all individual species analyzed. Masked shrews were more abundant in interior than edge trapping locations $\left(F_{1,56}=4.66, P=0.035\right)$, while 
meadow voles $\left(F_{1,56}=6.81, P=0.012\right)$ and southern bog lemmings $\left(F_{1,56}=12.94, P=\right.$ 0.001) were more abundant in edge locations. All other species analyzed produced similar abundances in edge and interior trapping locations: Peromyscus spp. $\left(F_{1,56}=\right.$ $0.36, P=0.553)$, smoky shrew $\left(F_{1,56}=1.09, P=0.301\right)$, northern short-tailed shrew $\left(F_{1}\right.$, $\left.{ }_{56}=0.23, P=0.635\right)$, woodland jumping mouse $\left(F_{1,56}=1.34, P=0.251\right)$, meadow jumping mouse $\left(F_{1,56}=0.57, P=0.453\right)$, southern red-backed vole $\left(F_{1,56}=0.28, P=\right.$ $0.599)$, eastern chipmunk $\left(F_{1,56}=1.32, P=0.256\right)$, and long-tailed shrew $\left(F_{1,56}=0.81, P\right.$ $=0.371)$. Meadow voles $\left(F_{1,56}=5.66, P=0.021\right)$ and red-backed voles $\left(F_{1,56}=4.35, P\right.$ $=0.042$ ) were more abundant in upland than riparian habitats. Other species analyzed produced similar $\mathrm{CPU}$ values between habitats: masked shrew $\left(F_{1,56}=0.94, P=0.336\right)$, Peromyscus spp. $\left(F_{1,56}=1.58, P=0.214\right)$, smoky shrew $\left(F_{1,56}=0.02, P=0.887\right)$, northern short-tailed shrew $\left(F_{1,56}=1.21, P=0.276\right)$, woodland jumping mouse $\left(F_{1,56}=\right.$ $0.71, P=0.404)$, meadow jumping mouse $\left(F_{1,56}=1.74, P=0.193\right)$, southern bog lemming $\left(F_{1,56}=1.49, P=0.227\right)$, eastern chipmunk $\left(F_{1,56}=2.96, P=0.091\right)$, and longtailed shrew $\left(F_{1,56}=0.04, P=0.837\right)$. No interactions were observed between habitat and trapping location for species abundances (Appendix IIIb).

Average species richness was higher in riparian than upland sites $\left(F_{1,56}=4.50, P\right.$ $=0.038)$, but similar between edge and interior sites $\left(F_{1,56}=1.23, P=0.271\right)($ Table 1$)$. Pielou's evenness index was similar between habitats $\left(F_{1,56}=1.48, P=0.228\right)$ and locations $\left(F_{1,56}=3.45, P=0.069\right)$. Shannon diversity of small mammals was higher in riparian than upland trapping sites $\left(F_{1,56}=5.38, P=0.024\right)$. Diversity also was higher in edge than interior trapping arrays $\left(F_{1,56}=4.02, P=0.050\right)$. No significant interactions between habitat and location were observed for diversity measures (Appendix IIIb). 
Average mass of smoky shrew was higher in riparian than upland sites $\left(F_{1,506}=\right.$ 6.17, $P=0.013$ ) (Table 1). Mass of other species analyzed was similar between habitats: masked shrew $\left(F_{1,1344}=0.51, P=0.475\right)$, Peromyscus spp. $\left(F_{1,754}=0.33, P=0.567\right)$, northern short-tailed shrew $\left(F_{1,335}=1.06, P=0.304\right)$, and woodland jumping mouse $\left(F_{1}\right.$, $\left.{ }_{453}=0.03, P=0.874\right)$. Average mass of all species analyzed was similar between edge and interior trapping arrays: masked shrew $\left(F_{1,1344}=2.20, P=0.138\right)$, Peromyscus spp. $\left(F_{1,754}=0.33, P=0.564\right)$, smoky shrew $\left(F_{1,506}=1.31, P=0.254\right)$, northern short-tailed shrew $\left(F_{1,335}=2.49, P=0.115\right)$, and woodland jumping mouse $\left(F_{1,453}=3.36, P=0.068\right)$. No significant interactions between habitat and location were observed for species analyzed (Appendix IIIc).

Ratio of males to females was higher in interior than edge sites for the smoky shrew $\left(F_{1,48}=8.00, P=0.007\right)($ Table 1$)$. All other species analyzed produced similar ratio of males to female values in habitat locations: masked shrew $\left(F_{1,56}=1.34, P=\right.$ $0.259)$, Peromyscus spp. $\left(F_{1,52}=1.64, P=0.206\right)$, northern short-tailed shrew $\left(F_{1,51}=\right.$ $1.53, P=0.221)$, and woodland jumping mouse $\left(F_{1,47}=0.07, P=0.799\right)$. The woodland jumping mouse produced higher ratio of male to female values in riparian than upland trapping arrays $\left(F_{1,47}=5.86, P=0.019\right)$. All other species analyzed showed similar ratio of males to females between habitats: masked shrew $\left(F_{1,56}=0.00, P=0.984\right)$, Peromyscus spp. $\left(F_{1,52}=0.07, P=0.799\right)$, smoky shrew $\left(F_{1,48}=1.35, P=0.250\right)$, and northern short-tailed shrew $\left(F_{1,51}=0.84, P=0.364\right)$. Interactions between habitat and location were not significant for ratio of males to females of analyzed species (Appendix IIId). The interaction term between habitat and location was significant for the proportion of reproductive female Peromyscus spp. $\left(F_{1,52}=7.66, P=0.008\right)$. No 
reproductive female Peromyscus spp. were captured in riparian interior sites. Thus, riparian interior sites $(\bar{x}=0.00, \mathrm{SE}=0.00)$ produced lower proportion of reproductive females than riparian edge sites $(\bar{x}=0.14, \mathrm{SE}=0.04)\left(t_{52}=3.47, P=0.001\right)$, upland edge sites $(\bar{x}=0.11, \mathrm{SE}=0.03)\left(t_{52}=3.14, P=0.003\right)$, and upland interior sites $(\bar{x}=$ $0.08, \mathrm{SE}=0.02)\left(t_{52}=2.90, P=0.005\right)$. Proportion of reproductive female Peromyscus spp. was similar between riparian edge and upland edge sites $\left(t_{52}=0.58, P=0.563\right)$, riparian edge and upland interior sites $\left(t_{52}=0.77, P=0.440\right)$, and upland edge and upland interior sites $\left(t_{52}=0.26, P=0.256\right)$. Other species analyzed produced similar proportion of reproductive females values between habitats: masked shrew $\left(F_{1,56}=1.38, P=0.246\right)$, smoky shrews $\left(F_{1,48}=2.01, P=0.163\right)$, northern short-tailed shrew $\left(F_{1,51}=1.74, P=\right.$ $0.193)$, woodland jumping mouse $\left(F_{1,47}=3.94, P=0.053\right)$ (Table 1$)$. These species also produced similar proportion of reproductive females values between edge and interior sites: masked shrew $\left(F_{1,56}=0.74, P=0.393\right)$, smoky shrews $\left(F_{1,48}=0.08, P=0.779\right)$, northern short-tailed shrew $\left(F_{1,51}=0.05, P=0.820\right)$, and woodland jumping mouse $\left(F_{1,47}\right.$ $=0.04, P=0.839)$. Interactions of habitat and location were not significant for proportion of reproductive females values of these species (Appendix IIIe).

\section{DISCUSSION}

Both species richness and diversity were higher in riparian than upland trapping locations indicating more species of small mammals are using riparian areas. Riparian zones generally support moister microclimates, that are preferred by most insectivores and many rodents (Whitaker and Wrigley 1972, Linzey 1983, Owens 1984, Merritt 1987). Riparian areas also may provide better quality habitat than uplands because soils are more suitable for burrowing mammals and insect abundance is generally higher 
(Borror et al. 1981, Doyle 1990). In the southwestern United States, Johnson and Lowe (1985) described the gradient from riparian to upland as a major influence in the structure of small mammal communities (McComb et al. 1993). Doyle (1990) found that abundance, diversity, and richness of small mammals were higher in riparian than upland sites in Oregon. Another study in Oregon showed diversity of small mammals to be higher in riparian than upland sites, but no difference in richness between the 2 habitat types was observed (McComb et al. 1993). In the Midwest, Geier and Best (1980) found small mammal diversity was higher in channelized stream habitats than floodplains and upland areas. However, Laerm et al. (1997) found no difference between species richness, diversity, or evenness between riparian and upland sites in the southern Appalachians. These authors believed lack of difference in general vegetative structure was the cause for their findings. Vegetative structure for my study was relatively similar between riparian and upland sites with the exception of rock volume, which was higher in riparian sites (Spurgeon 2002). Canopy closure, \% herbaceous ground cover, and basal area were slightly higher in riparian than upland sites for my pitfalls, but statistically these measures were similar (Spurgeon 2002). Laerm et al. (1997) used live traps and small 0.91 pitfall cups. It is likely that the pitfall arrays with drift fences used in my study were more efficient in sampling the entire community of small mammals at upland and riparian sites.

Though, overall abundance of small mammals was similar between riparian and upland trapping locations, meadow voles and southern red-backed voles were both more abundant in upland trapping grids. In North Carolina, Laerm et al. (1997) found no difference in small mammal abundance between riparian and adjacent upland habitats. 
The only exception noted by Laerm et al. (1997) was northern short-tailed shrew abundance, which was higher in upland sites than riparian areas. Abundance of northern short-tailed shrews on our study site was similar between riparian and upland habitats, as was abundance of masked shrew and Peromyscus spp. All 3 of these species are habitat generalists tolerating a broad variety of environmental conditions and inhabiting most habitat types in equal abundance (Lackey et al. 1985, George et al. 1986, Merritt 1987).

Optimum habitat for meadow voles is moist fields and grassy lowlands characterized by grasses, sedges, and rushes (Reich 1981, Merritt 1987). However, these microtine rodents are common and widespread inhabiting old field and abandoned agricultural land where available. About $50 \%$ of the upland trapping arrays in this study were set in reclaimed mine fields and old agricultural lands that become moist after heavy rain events (Vanderhorst 2001). These fields were classified as upland because of their distance to a permanent water source. Wet meadows are uncommon in the central Appalachians, and none of the riparian trapping arrays in this study were located in grassy meadows (Vanderhorst 2001, Spurgeon 2002). Thus, meadow voles captured in this study were found in dry, upland fields on reclaimed mine sites and abandoned agricultural land in the floodplain of the Cheat River but $>100 \mathrm{~m}$ from the river itself.

The southern red-backed vole is commonly found in deciduous and mixed forest environments associated with rocky outcroppings (Burt and Grossenheider 1980, Merritt 1987). Most of the upland mature hardwood habitat associated with rocky outcroppings on the study site provides cool climates and extensive fern and moss cover, which is preferred by southern red-backed voles (Merritt 1987, Streets 2001, Vanderhorst 2001). Southern red-backed voles in North Carolina were found to be equally abundant in 
riparian and forested areas with similar vegetative communities (Laerm et al. 1997). However, Darveau et al. (2001) found these rodents were less abundant in the first $20 \mathrm{~m}$ adjacent to streams than further into forested environments. In Oregon, the western redbacked vole (Clethrionomys californicus) was captured more frequently in upslope habitats than streamside areas (McComb et al. 1993).

Average mass of smoky shrews and male to female ratio of woodland jumping mice were both higher in riparian than upland habitats suggesting riparian habitats are providing heavier smoky shrews and being selected by male woodland jumping mice. As mentioned above, riparian areas generally provide higher invertebrate abundance than upland areas (Borror et al. 1981, Doyle 1990). Invertebrates are the main food item for smoky shrews, and the occurrence of heavier shrews in riparian habitats is probably associated with higher abundance of invertebrates in riparian habitats on the study site (Owens 1984, Merritt 1987). Doyle (1990) suggested that riparian sites were a source for small mammal breeding, and adjacent upland areas represented dispersal sinks for juveniles in the Pacific Northwest when he found more reproductively active males in riparian than associated upland sites. No reproductive female Peromyscus spp. were captured in riparian interior sites in my study. This phenomenon could be attributed to Doyle's (1990) theory that reproductively active males exhibit dominance over reproductive females and juveniles thereby securing optimal streamside habitat. The higher male to female ratio of woodland jumping mice in riparian zones on the CDCTA also contributes to this theory.

Though species richness and evenness were similar between edge and interior trapping sites, diversity was higher in edge than interior sites. On average, the same 
number of species was sampled in edge and interior habitats, but less dominance by a few species was observed in edge habitats. Edge habitats generally produce a wider variety of vegetative species for forage and access to multiple habitat types (Leopold 1933, Odum 1959, Lidicker 1999). My findings support results produced by Sekgororoane and Dilworth (1995), who also found species diversity to be higher in forest edges than interior sites in New Brunswick. These authors also observed similar richness values between edge and interior sites. In Tennessee, Johnson et al. (1979) found species richness and diversity were higher in ecotone regions between powerline right-of-ways and adjacent forests than in the associated forest interiors. Many of the forest edges on the CDCTA were adjacent to reclaimed mine land that had succeeded into old field habitat (Vanderhorst 2001).

Masked shrews were more abundant in interior habitats, while meadow voles and southern bog lemmings were more abundant in edge habitats indicating a difference in habitat selection by these species. Masked shrews are typically associated with moist, rocky forested habitat, which is more prevalent in interior than edge sites on the CDCTA (Chapter II) (Merritt 1987). Another reason for higher masked shrew abundance in interior sites may be the influence of predation along forest and road edges (Stevens and Husband 1998). In western North Carolina, masked shrews and southern red-backed voles exhibited higher relative abundances in edge/ecotone regions of the gradient (Menzel et al. 1999), which is contrary to our findings regarding the masked shrew. The study by Menzel et al. (1999) and my study indicate that edge may not be a critical factor in determining habitat selection by masked shrews. Because masked shrews are widespread and abundant in most habitat types, the difference in abundance of masked 
shrews between edge and interior sites in my study could be attributed to some unmeasured factor such as prey availability or predator influence.

Meadow voles and southern bog lemmings generally coexist in wet meadows, powerline right of ways, pastures, and old fields, but both species also can be found in hardwood forests in the Appalachians (Reich 1981, Linzey 1983). As mentioned above, edge habitats provide a variety of early successional plant species and access to different habitat types (Lidicker 1999). Several of the edge sites in this study were located at the junction of forest and open field or scrub-shrub environments. Because meadow voles and southern bog lemmings are found in old fields and forest environments, it is logical that these species were captured more frequently in edge than habitat interior trapping arrays.

Other species analyzed showed similar abundance in edge and interior sites indicating no difference in use of edge and interior sites by these species. In North Carolina, Menzel et al. (1999) found smoky shrews, woodland voles (Microtus pinetorum), white-footed mice, and woodland jumping mice were equally abundant across a gradient from forest interior to wildlife openings. Heske (1995) found no significant difference between abundance of small mammals on interior plots and forestfarm edges in southern Illinois. This author cautioned that site-to-site variability could have impeded his ability to detect differences between edge and interior abundances. Variability in trapping success was low between edge and interior sites in my study.

Average mass of the species analyzed was similar between edge and interior sites, indicating no difference in the size of animals between edge and interior trapping sites. However, the ratio of male to female smoky shrews was higher in interior than edge sites. 
Interior habitats usually provide cooler, moister climates that are preferred by the smoky shrew (Owens 1984, Merritt 1987). Males are most likely the dominant sex in this species and seem to be selecting interior sites as optimal habitat (Owens 1984). Proportion of reproductive females of the species analyzed in this study were similar between edge and interior sites suggesting that an equal amount of reproduction is occurring in edge and interior sites on the study area. Overall, condition of small mammals on the CDCTA appears to be similar between edge and interior sites.

Few studies have focused on small mammal community structure in relation to roadsides or right of ways (ROWs). One comprehensive study of the effects of roads on small mammals by Adams and Geis (1983) evaluated these questions in the southeast, Midwest, and northwest United States. These authors found that both interstate and country roads influenced small mammal density and community structure in different ways. Interstate ROWs contained more small mammal species and higher densities than adjacent habitat, and ROWs along country roads showed lower small mammal densities than adjacent habitat. All of the roads on the CDCTA are unpaved and would be considered country roads. Over $50 \%$ of the edge arrays in my study were at the junction of a road and adjacent habitat. Because diversity of small mammals was higher in edge than interior sites, it appears that early successional vegetation associated with road edges on the CDCTA provides habitat for a more diverse small mammal community than more open interior sites.

\section{MANAGEMENT IMPLICATIONS}

Higher diversity in riparian habitats signifies the need for conservation of riparian habitat in the central Appalachians. Higher abundance of meadow voles and southern 
red-backed voles in upland areas indicates that both riparian and upland habitats should be protected to support the greatest abundance and diversity of small mammal species. Maintenance of riparian strips or designation of riparian management zones would provide protection of streamside environments from activities such as military activity, and logging, which are major impacts on the study area (McComb et al. 1993, WVARNG 2001).

Evidence of edge effect is present in diversity estimates on the CDCTA, and managers should be aware that edge habitats should be protected and maintained to promote a diverse small mammal community. No distinction was made between hard and soft edges or forest and road edges in the analysis of this research. There are many types of edge habitat and different types of edge provide different benefits for various taxa (Ratti and Reese 1988, Yahner 1988, Heske 1995). Hard edges, like road edges and agriculture/forest junctions, are generally considered less beneficial to wildlife than softer edges that provide a gradient from open land to early successional habitat to forest environments (Heske 1995, Lidicker 1999). All the edges analyzed in this study were hard edges at road/habitat and habitat/habitat junctions. Further investigation of small mammal populations in different types of forest edge would provide valuable information on the benefits and drawbacks of specific management practices for promoting beneficial edge habitats for wildlife.

Monitoring programs targeted at small mammals should include sampling in riparian and upland habitats to ensure full-coverage sampling and estimation of local small mammal populations (Doyle 1990, McComb et al. 1993, Ford and Rodrigue 2001). Edge and interior locations also should be considered when monitoring mammalian 
species (Sekgororoane and Dilworth 1995, Menzel 1999). Small mammal populations have been shown to fluctuate from year to year and low to peak levels in somewhat cyclic patterns (Darveau et al. 2001). To ascertain the best information available on the mammalian species of central Appalachian environments, monitoring protocols should be established that incorporate riparian and upland habitats, edge and interior locations, and multiple years of sampling. 


\section{LITERATURE CITED}

Adams, L. W., and A. D. Geis. 1983. Effects of roads on small mammals. Journal of Applied Ecology 20:403-415.

Bayne, E. M., and K. A. Hobson. 1998. The effects of habitat fragmentation by forestry and agriculture on the abundance of small mammals in the southern boreal mixed wood forest. Canadian Journal of Zoology 76:62-69.

Bell, J.W. 2001. Soil survey of Camp Dawson, Preston County, West Virginia. U.S. Department of Agriculture. Natural Resources Conservation Service.

Borror, D. J., D. M. DeLong, and C. A. Triplehorn. 1981. An introduction to the study of insects. Saunders College Publishers, Philadelphia, Pennsylvania, USA.

Burt, W. H., and R. P. Grossenheider. 1998. A field guide to mammals of North America to Mexico: Third Edition. the Peterson Field Guide Series. Houghton Mifflin, New York, USA.

Bury, R. B., and P. S. Corn. 1987. Evaluation of pitfall trapping in northwestern forests: trap arrays with drift fences. Journal of Wildlife Management 51:112-119.

Clark, B. K., B. S. Clark, L. A. Johnson, and M. T. Haynie. 2001. Influence of roads on movements of small mammals. Southwestern Naturalist 46:338-344.

Clevenger, A. P., and N. Waltho. 2000. Factors influencing the effectiveness of wildlife underpasses in Banff National Park, Alberta, Canada. Conservation Biology $14: 47-56$.

Coolinge, S. K. 1996. Ecological consequences of habitat fragmentation: implications for landscape architecture and planning. Landscape and Urban Planning 36:5977. 
Darveau, M., P. Labbe, P. Beauchesne, L. Belanger, and J. Huot. 2001. The use of riparian strips by small mammals in a boreal balsam fir forest. Forest Ecology and Management 143:95-104.

Dickson, J. G., J. H. Williamson, R. N. Conner, and B. Ortego. 1995. Streamside zones and breeding birds in eastern Texas. Wildlife Society Bulletin 23:750-755.

Dowdy, S., and Wearden, S. 1991. Statistics for research. John Wiley and Sons, New York, New York, USA.

Doyle, A. T. 1990. Use of riparian and upland habitats by small mammals. Journal of Mammalogy 71:14-23.

Ford, W. M., and J. L. Rodrigue. 2001. Soricid abundance in partial overstory removal harvests and riparian areas in an industrial forest landscape of the central Appalachians. Forest Ecology and Management 152:159-168.

Gates, J. E., and L. W. Geysel. 1978. Avian nest dispersion and fledgling success in field-forest ecotones. Ecology 59:871-883.

Geier, A. R., and L. S. Best. 1980. Habitat selection by small mammals of riparian communities: evaluating effects of habitat alterations. Journal of Wildlife Management 44:16-24.

George, S. B., J. R. Choate, and H. H. Genoways. 1986. Blarina brevicauda. Mammalian Species 261:1-9.

Greenberg, C. H., D. G. Neary, and L. D. Harris. 1994. A comparison of herpetofaunal sampling effectiveness of pitfall, single-ended, and double-ended funnel traps used with drift fences. Journal of Herpetology 28:319-324. 
Harris, L. D. 1988. Edge effects and conservation of biotic diversity. Conservation Biology 2:330-332.

Heske, E. J. 1995. Mammalian abundances on forest-farm edges versus forest interiors in southern Illinois: Is there an edge effect? Journal of Mammalogy 76:562-568.

Johnson, R. R., and C. H. Lowe. 1985. On the development of riparian ecology. Pages 112-116 in Proceedings of the symposium on riparian ecosystems and their management. United States Department of Agriculture Forest Service General Technical Report RM 120.

Johnson, W. C., R. K. Schreiber, and R. L. Burgess. 1979. Diversity of small mammals in a powerline right-of-way and adjacent forest in east Tennessee. American Midland Naturalist 10:231-235.

Kilgo, J. C., R. A. Sargent, B. R. Chapman, and K. V. Miller. 1998. Effect of stand width and adjacent habitat on breeding bird communities in bottomland hardwoods. Journal of Wildlife Management 62:72-83.

Knopf, F. L., R. R. Johnson, T. Rich, F. B. Samson, and R. C. Szaro. 1988. Conservation of riparian ecosystems in the United States. Wilson Bulletin 100:278-284.

Krohne, D. T. 1998. General ecology. Wadsworth, Belmont, California, USA.

Lackey, J. A., D. G. Huckaby, and B. G. Ormiston. 1985. Peromyscus leucopus. Mammalian Species 247:1-10. 
Laerm, J., M. A. Menzel, D. J. Wolf, and J. R. Welch. 1997. The effect of riparian zones in structuring small mammal communities in the southern Appalachians. Pages 132-145 in J. E. Cook and B. P. Oswald, compilers. Proceedings of the First Biennial North American Forest Ecology Workshop. Society of American Foresters, North Carolina State University, Raleigh, North Carolina, USA.

Leopold, A. 1933. Game management. Charles Scribner's Sons, New York, USA.

Lidicker, W. Z., Jr. 1999. Responses of mammals to habitat edges: an overview. Landscape Ecology 14:333-343.

Linzey, A. V. 1983. Synaptomys cooperi. Mammalian Species 210:1-5.

Magurran, A. E. 1988. Ecological diversity and its measurement. Princeton University Press, Princeton, New Jersey, USA.

McComb, W. C., K. McGarigal, and R. G. Anthony. 1993. Small mammal and amphibian abundance in streamside and upslope habitats of mature Douglas fir stands of western Oregon. Northwest Science 67:7-15.

Mengak, M. T., and D. C. Guynn. 1987. Pitfalls and snap traps for sampling small mammals and herpetofauna. American Midland Naturalist 118:284-288.

Menzel, M. A., W. M. Ford, J. Laerm, and D. Krishon. 1999. Forest to wildlife openings: habitat gradient analysis among small mammals in the southern Appalachians. Forest Ecology and Management 114:227-232.

Merriam, G., M. Kozakiewicz, M. Tsuchiya, and K. Hawley. 1989. Barriers as boundaries for metapopulations and homes of Peromyscus leucopus in farm landscapes. Landscape Ecology 2:227-235. 
Merritt, J. F. 1987. Mammals of Pennsylvania. University of Pittsburgh Press, Pittsburgh, Pennsylvania, USA.

Moller, A. P. 1989. Nest site selection across field-woodland ecotones: the effect of nest predation. Oikos 56:240-246.

Nupp, T. E., and R. K. Swihart. 2000. Landscape-level correlates of small-mammal assemblages in forest fragments of farmland. Journal of Mammalogy 81:512-526.

Odum, E. P. 1959. Fundamentals of ecology. W. B. Saunders, Philadelphia, Pennsylvania, USA.

Oxley, D. J., M. B. Fenton, and G. R. Carmody. 1974. The effects of roads on populations of small mammals. Journal of Applied Ecology 11:51-59.

Owens, J. G. 1984. Sorex fumeus. Mammalian species 215:1-8.

Pasitshcniak-Arts, M., and F. Messier. 1998. Effects of edges and habitats on small mammals in a prairie ecosystem. Canadian Journal of Zoology 76:2020-2025.

Pielou, E. C. 1966. The measurement of diversity in different types of biological collections. Journal of Theoretical Biology 13:131-144.

Pulliam, H. R., J. B. Dunning, Jr., and J. Liu. 1992. Population dynamics in complex landscapes: a case study. Ecological Applications 2:165-177.

Ratti, J. T., and K. P. Reese. 1988. Preliminary test of the ecological trap hypothesis. Journal of Wildlife Management 52:484-491.

Reich, L. M. 1981. Microtus pennsylvanicus. Mammalian Species 159:1-8.

Richardson, J. H., R. F. Shore, and J. R. Treweek. 1997. Are major roads a barrier to small mammals? Journal of Zoology 243:840-846. 
Sekgororoane, G. B., and T. G. Dilworth. 1995. Relative abundance, richness, and diversity of small mammals at induced forest edges. Canadian Journal of Zoology 73:1432-1437.

Spurgeon, A. B. 2002. Comparison of herpetofaunal species' composition and response to edge on the Camp Dawson Collective Training Area, Preston County, West Virginia. Thesis, West Virginia University, Morgantown, West Virginia, USA.

Stevens, S. M., and T. P. Husband. 1998. The influence of edge on small mammals: evidence from Brazilian Atlantic forest fragments. Biological Conservation 85:18.

Streets, B. P. 2001. Floristic inventory of the Camp Dawson Army Training Site, Preston County, West Virginia. Nongame Wildlife and Natural Heritage Program, Wildlife Resources Section, Division of Natural Resources, Elkins, West Virginia.

Thurmond, D. P., and K. V. Miller. 1994. Small mammal communities in streamside management zones. Brimleyana 0:125-130.

Thurmond, D. P., Miller, K. V., and T. G. Harris. 1995. Effect of streamside management zone width on avifauna communities. Southern Journal of Applied Forestry 19:166-169.

Vanderhorst, J. 2001. Plant community classification and mapping of Camp Dawson Collective Training Area, Preston County, West Virginia. Nongame Wildlife and Natural Heritage Program, Wildlife Resources Section, Division of Natural Resources, Elkins, West Virginia, USA. 
Viles, R. L., and D. J. Rosier. 2001. How to use roads in the creation of greenways: Case studies in three New Zealand landscapes. Landscape and Urban Planning 55:15-27.

West Virginia Army Reserve National Guard (WVARNG). 2001. Integrated Natural Resources Management Plan. Camp Dawson, Preston County, West Virginia, USA.

Whitaker, D. M., and W. A. Montevecchi. 1997. Breeding bird assemblages associated with riparian, interior forest, and nonriparian edge habitats in a balsam fir ecosystem. Canadian Journal of Forest Research 27:1159-1167.

Whitaker, J. O., Jr., and R. E. Wrigley. 1972. Napaeozapus insignis. Mammalian Species 14:1-6.

White, G. C., D. R. Anderson, K. P. Burnham, and D. L. Otis. 1982. Capture-recapture and removal methods for sampling closed populations. LA-8787-NERP, Los Alamos National Laboratory, Los Alamos, New Mexico, USA.

Wilkins, R. N., and N. P. Peterson. 2000. Factors related to amphibian occurrence and abundance in headwater streams draining second-growth Douglas-fir forests in southwestern Washington. Forest Ecology and Management 139:79-91.

Wilson, D. E., and D. M. Reeder, editors. 1993. Mammal Species of the World. Smithsonian Institution Press, Washington, D. C., USA.

Yahner, R. H. 1988. Changes in wildlife communities near edges. Conservation Biology 2:333-338. 
Yoakum, J., and W. P. Dasman. 1969. Habitat manipulation practices. Pages 173-231 in R. H. Giles, Jr. editor. Wildlife management techniques. Third edition. The Wildlife Society, Washington, D. C.

Zar, J. H. 1999. Biostatistical analysis. Fourth edition. Prentice Hall, Upper Saddle River, New Jersey, USA. 
Table 1. Average relative abundance in captures per 100 trap nights (CPU), species richness, Pielou's Evenness Index, Shannon Diversity Index, average mass (g), ratio of males to females, and proportion of reproductive females values for small mammal species captured in pitfall traps in riparian and upland habitats and edge and interior trapping locations on the Camp Dawson Collective

Training Area in Preston County, West Virginia during 2000 and 2001.

\begin{tabular}{|c|c|c|c|c|c|c|c|c|}
\hline \multirow[b]{3}{*}{ Species or Index } & \multicolumn{4}{|c|}{ Habitat $^{\mathrm{a}}$} & \multicolumn{4}{|c|}{ Location $^{\mathrm{a}}$} \\
\hline & \multicolumn{2}{|c|}{ Riparian } & \multicolumn{2}{|c|}{ Upland } & \multicolumn{2}{|c|}{ Edge } & \multicolumn{2}{|c|}{ Interior } \\
\hline & $\bar{x}$ & $\mathrm{SE}$ & $\bar{x}$ & $\mathrm{SE}$ & $\bar{x}$ & $\mathrm{SE}$ & $\bar{x}$ & $\mathrm{SE}$ \\
\hline \multicolumn{9}{|l|}{$\overline{\mathrm{CPU}}$} \\
\hline masked shrew & $2.39 \mathrm{a}$ & 0.30 & $3.94 \mathrm{a}$ & 0.51 & $2.68 b$ & 0.41 & $4.30 \mathrm{a}$ & 0.60 \\
\hline Peromyscus spp. & $1.20 \mathrm{a}$ & 0.23 & $2.24 \mathrm{a}$ & 0.27 & $1.63 \mathrm{a}$ & 0.23 & $2.20 \mathrm{a}$ & 0.35 \\
\hline smoky shrew & $0.87 \mathrm{a}$ & 0.11 & $1.27 \mathrm{a}$ & 0.24 & $0.91 \mathrm{a}$ & 0.17 & $1.40 \mathrm{a}$ & 0.30 \\
\hline woodland jumping mouse & $1.56 \mathrm{a}$ & 0.58 & $1.11 \mathrm{a}$ & 0.24 & $0.86 \mathrm{a}$ & 0.20 & $1.73 \mathrm{a}$ & 0.48 \\
\hline northern short-tailed shrew & $0.54 \mathrm{a}$ & 0.09 & $0.90 \mathrm{a}$ & 0.13 & $0.75 \mathrm{a}$ & 0.11 & $0.81 \mathrm{a}$ & 0.15 \\
\hline meadow jumping mouse & $1.56 \mathrm{a}$ & 0.40 & $1.34 \mathrm{a}$ & 0.66 & $1.36 \mathrm{a}$ & 0.39 & $1.47 \mathrm{a}$ & 0.89 \\
\hline meadow vole & $0.35 b$ & 0.12 & $0.73 a$ & 0.18 & $0.80 \mathrm{a}$ & 0.20 & $0.36 \mathrm{~b}$ & 0.14 \\
\hline
\end{tabular}


Table 1. Continued.

\begin{tabular}{|c|c|c|c|c|c|c|c|c|}
\hline \multirow[b]{3}{*}{ Species or Index } & \multicolumn{4}{|c|}{ Habitat $^{\mathrm{a}}$} & \multicolumn{4}{|c|}{ Location $^{\mathrm{a}}$} \\
\hline & \multicolumn{2}{|c|}{ Riparian } & \multicolumn{2}{|c|}{ Upland } & \multicolumn{2}{|c|}{ Edge } & \multicolumn{2}{|c|}{ Interior } \\
\hline & $\bar{x}$ & SE & $\bar{x}$ & SE & $\bar{x}$ & SE & $\bar{x}$ & SE \\
\hline southern red-backed vole & $0.10 \mathrm{~b}$ & 0.03 & $0.35 \mathrm{a}$ & 0.07 & $0.23 \mathrm{a}$ & 0.07 & $0.31 \mathrm{a}$ & 0.07 \\
\hline southern bog lemming & $0.17 \mathrm{a}$ & 0.05 & $0.12 \mathrm{a}$ & 0.03 & $0.21 \mathrm{a}$ & 0.04 & $0.04 \mathrm{~b}$ & 0.02 \\
\hline eastern chipmunk & $0.22 \mathrm{a}$ & 0.11 & $0.08 \mathrm{a}$ & 0.03 & $0.11 \mathrm{a}$ & 0.04 & $0.14 \mathrm{a}$ & 0.08 \\
\hline long-tailed shrew & $0.05 \mathrm{a}$ & 0.03 & $0.05 \mathrm{a}$ & 0.01 & $0.03 \mathrm{a}$ & 0.02 & $0.06 \mathrm{a}$ & 0.02 \\
\hline Total CPU & $9.10 \mathrm{a}$ & 1.45 & $12.23 \mathrm{a}$ & 1.05 & $9.69 \mathrm{a}$ & 0.99 & $12.94 \mathrm{a}$ & 1.43 \\
\hline Species Richness & $9.71 \mathrm{a}$ & 0.31 & $8.71 b$ & 0.35 & $9.24 \mathrm{a}$ & 0.38 & $8.83 \mathrm{a}$ & 0.35 \\
\hline Pielou's Evenness Index & $0.79 \mathrm{a}$ & 0.02 & $0.76 \mathrm{a}$ & 0.02 & $0.79 a$ & 0.02 & $0.74 \mathrm{a}$ & 0.02 \\
\hline Shannon Diversity Index & $1.79 \mathrm{a}$ & 0.04 & $1.62 b$ & 0.05 & $1.74 \mathrm{a}$ & 0.05 & $1.61 b$ & 0.06 \\
\hline
\end{tabular}


Table 1. Continued.

\begin{tabular}{|c|c|c|c|c|c|c|c|c|}
\hline \multirow[b]{3}{*}{ Species or Index } & \multicolumn{4}{|c|}{ Habitat $^{\mathrm{a}}$} & \multicolumn{4}{|c|}{ Location $^{\mathrm{a}}$} \\
\hline & \multicolumn{2}{|c|}{ Riparian } & \multicolumn{2}{|c|}{ Upland } & \multicolumn{2}{|c|}{ Edge } & \multicolumn{2}{|c|}{ Interior } \\
\hline & $\bar{x}$ & $\mathrm{SE}$ & $\bar{x}$ & $\mathrm{SE}$ & $\bar{x}$ & $\mathrm{SE}$ & $\bar{x}$ & SE \\
\hline \multicolumn{9}{|l|}{ Mass } \\
\hline masked shrew & $4.20 \mathrm{a}$ & 0.05 & $4.13 \mathrm{a}$ & 0.03 & $4.11 \mathrm{a}$ & 0.04 & $4.19 \mathrm{a}$ & 0.03 \\
\hline smoky shrew & $7.45 \mathrm{a}$ & 0.13 & $7.19 b$ & 0.09 & $7.16 \mathrm{a}$ & 0.10 & $7.42 \mathrm{a}$ & 0.11 \\
\hline northern short-tailed shrew & $17.25 \mathrm{a}$ & 0.36 & $16.56 \mathrm{a}$ & 0.27 & $17.11 \mathrm{a}$ & 0.31 & $16.50 \mathrm{a}$ & 0.3 \\
\hline Peromyscus spp. & $17.32 \mathrm{a}$ & 0.39 & $17.36 \mathrm{a}$ & 0.24 & $17.28 \mathrm{a}$ & 0.30 & $17.40 \mathrm{a}$ & 0.29 \\
\hline woodland jumping mouse & $18.77 \mathrm{a}$ & 0.33 & $18.79 \mathrm{a}$ & 0.27 & $18.34 \mathrm{a}$ & 0.34 & $19.10 \mathrm{a}$ & 0.27 \\
\hline \multicolumn{9}{|l|}{ Ratio of males to females } \\
\hline masked shrew & $1.28 \mathrm{a}$ & 0.17 & $1.30 \mathrm{a}$ & 0.12 & $1.15 \mathrm{a}$ & 0.14 & $1.47 \mathrm{a}$ & 0.14 \\
\hline smoky shrew & $1.05 \mathrm{a}$ & 0.18 & $1.04 \mathrm{a}$ & 0.16 & $0.74 b$ & 0.14 & $1.38 \mathrm{a}$ & 0.17 \\
\hline northern short-tailed shrew & $1.19 \mathrm{a}$ & 0.40 & $1.15 \mathrm{a}$ & 0.26 & $0.89 \mathrm{a}$ & 0.19 & $1.49 \mathrm{a}$ & 0.41 \\
\hline Peromyscus spp. & $2.24 \mathrm{a}$ & 0.78 & $1.17 \mathrm{a}$ & 0.12 & $1.20 \mathrm{a}$ & 0.17 & $1.96 \mathrm{a}$ & 0.59 \\
\hline
\end{tabular}


Table 1. Continued.

\begin{tabular}{|c|c|c|c|c|c|c|c|c|}
\hline \multirow[b]{3}{*}{ Species or Index } & \multicolumn{4}{|c|}{ Habitat $^{\mathrm{a}}$} & \multicolumn{4}{|c|}{ Location $^{\mathrm{a}}$} \\
\hline & \multicolumn{2}{|c|}{ Riparian } & \multicolumn{2}{|c|}{ Upland } & \multicolumn{2}{|c|}{ Edge } & \multicolumn{2}{|c|}{ Interior } \\
\hline & $\bar{x}$ & $\mathrm{SE}$ & $\bar{x}$ & $\mathrm{SE}$ & $\bar{x}$ & $\mathrm{SE}$ & $\bar{x}$ & $\mathrm{SE}$ \\
\hline woodland jumping mouse & $1.78 \mathrm{a}$ & 0.51 & $0.86 b$ & 0.14 & $1.24 \mathrm{a}$ & 0.34 & $1.09 \mathrm{a}$ & 0.21 \\
\hline \multicolumn{9}{|c|}{ Proportion of reproductive females } \\
\hline masked shrew & $0.07 \mathrm{a}$ & 0.02 & $0.05 \mathrm{a}$ & 0.01 & $0.07 \mathrm{a}$ & 0.02 & $0.04 \mathrm{a}$ & 0.01 \\
\hline smoky shrew & $0.08 \mathrm{a}$ & 0.03 & $0.07 \mathrm{a}$ & 0.02 & $0.07 \mathrm{a}$ & 0.02 & $0.07 \mathrm{a}$ & 0.02 \\
\hline northern short-tailed shrew & $0.08 \mathrm{a}$ & 0.05 & $0.08 \mathrm{a}$ & 0.03 & $0.05 \mathrm{a}$ & 0.02 & $0.12 \mathrm{a}$ & 0.05 \\
\hline Peromyscus spp. & $0.10 \mathrm{a}$ & 0.03 & $0.09 \mathrm{a}$ & 0.02 & $0.12 \mathrm{a}$ & 0.02 & $0.06 \mathrm{a}$ & 0.01 \\
\hline woodland jumping mouse & $0.18 \mathrm{a}$ & 0.06 & $0.08 \mathrm{a}$ & 0.03 & $0.12 \mathrm{a}$ & 0.04 & $0.10 \mathrm{a}$ & 0.04 \\
\hline
\end{tabular}

${ }^{a}$ The same letter following means indicates no significant difference $(P>0.05)$ between habitats or locations. 
Appendix Ia. Mammalian species with range maps overlapping the Camp Dawson Collective

Training Area (CDCTA) in Preston County, West Virginia (Burt and Grossenheider 1980,

Merritt 1987, Wilson and Reeder 1993). Species in bold are listed as rare or endangered by the

West Virginia Division of Natural Resources (2000). Species with an * were observed on the

CDCTA during 2000-2001.

\section{Order Marsupialia}

Family Didelphidae

*Virginia Opossum (Didelphis virginiana)

\section{Order Insectivora}

Family Sorcidae

*Masked Shrew (Sorex cinereus)

Water Shrew (Sorex palustris)

* Smoky Shrew (Sorex fumeus)

*Long-tailed Shrew (Sorex dispar)

* Pygmy Shrew (Sorex hoyi)

*Short-tailed Shrew (Blarina brevicauda)

Least Shrew (Cryptotis parva)

Family Talpidae

*Hairy-tailed Mole (Parascalops breweri)

Eastern Mole (Scalopus aquaticus)

*Star-nosed Mole (Condylura cristata)

\section{Order Chiroptera}

Family Vespertilionidae

*Little Brown Myotis (Myotis lucifugus)

*Northern Long-eared Myotis (Myotis septentrionalis)

Indiana Myotis (Myotis sodalis)

Eastern Small-footed Myotis (Myotis leibii)

Silver-haired Bat (Lasionycteris noctivagans)

*Eastern Pipistrelle (Pipistrellus subflavus)

* Big Brown Bat (Eptesicus fuscus)

*Red Bat (Lasiurus borealis)

*Hoary Bat (Lasiurus cinereus)

Evening Bat (Nycticeius humeralis) 
Appendix Ia. Continued

\section{Order Lagamorpha}

Family Leporidae

*Eastern Cottontail (Sylvilagus floridanus)

New England Cottontail (Sylvilagus transitionalis)

Snowshoe Hare (Lepus americanus)

\section{Order Rodentia}

Family Sciuridae

*Eastern Chipmunk (Tamias striatus)

*Woodchuck (Marmota monax)

*Gray Squirrel (Sciurus carolinensis)

*Fox Squirrel (Sciurus niger)

*Red Squirrel (Tamiasciurus hudsonicus)

*Southern Flying Squirrel (Glaucomys volans)

Northern Flying Squirrel (Glaucomys sabrinus)

Family Castoridae

*Beaver (Castor canadensis)

Family Muridae

* Deer Mouse (Peromyscus maniculatus)

*White-footed Mouse (Peromyscus leucopus)

*Allegheny woodrat (Neotoma magister)

*Red-backed Vole (Clethrionomys gapperi)

*Meadow Vole (Microtus pennsylvanicus)

*Yellownose (Rock) Vole (Microtus chrotorrhinus)

*Woodland (Pine) vole (Microtus pinetorum)

*Southern Bog Lemming (Synaptomys cooperi)

Muskrat (Ondatra zibethicus)

Norway Rat (Rattus norvegicus)

House Mouse (Mus musculus)

Family Dipodidae

*Meadow Jumping Mouse (Zapus hudsonius)

*Woodland Jumping Mouse (Napaeozapus insignis) 
Appendix Ia. Continued

\section{Order Carnivora}

Family Canidae

*Coyote (Canis latrans)

Red Fox (Vulpes vulpes)

Gray Fox (Urocyon cinereoargenteus)

Family Ursidae

*Black Bear (Ursus americanus)

Family Procyonidae

*Raccoon (Procyon lotor)

Family Mustelidae

*Least Weasel (Mustela nivalis)

*Long-tailed Weasel (Mustela frenata)

Mink (Mustela vison)

Eastern Spotted Skunk (Spilogale putorius)

*Striped Skunk (Mephitis mephitis)

Fisher (Martes pennanti)

Northern River Otter (Lontra canadensis)

Family Felidae

*Bobcat (Felis rufus)

\section{Order Artiodactyla}

Family Cervidae

*White-tailed Deer (Odocoileus virginianus) 
Appendix Ib. Total number of mammalian species captured on the Camp Dawson Collective Training Area in Preston County, West Virginia during 2000 and 2001.

\begin{tabular}{|c|c|c|c|c|c|c|c|c|}
\hline \multirow[b]{2}{*}{ Family } & \multirow[b]{2}{*}{ Common Name } & \multirow[b]{2}{*}{ Scientific Name } & \multicolumn{3}{|c|}{2000} & \multicolumn{3}{|c|}{2001} \\
\hline & & & $\mathrm{BM}$ & $\mathrm{CA}$ & $\mathrm{PT}$ & $\mathrm{BM}$ & $\mathrm{CA}$ & $\mathrm{PT}$ \\
\hline$\overline{\text { Didelphiidae }}$ & Virginia Opossum & Didelphis virginianus & 1 & 3 & 1 & 1 & 13 & 7 \\
\hline Soricidae & Masked Shrew & Sorex cinereus & 133 & 105 & 179 & 316 & 179 & 674 \\
\hline Soricidae & Smoky Shrew & Sorex fumeus & 8 & 29 & 32 & 85 & 120 & 309 \\
\hline Soricidae & Long-tailed Shrew & Sorex dispar & 2 & 0 & 5 & 4 & 2 & 13 \\
\hline Soricidae & Pygmy Shrew & Sorex hoyi & 0 & 0 & 0 & 1 & 1 & 1 \\
\hline Soricidae & Short-tailed Shrew & Blarina brevicauda & 21 & 59 & 34 & 46 & 147 & 304 \\
\hline Talpidae & Starnose Mole & Condylura cristata & 0 & 0 & 0 & 1 & 7 & 2 \\
\hline Talpidae & Hairytail Mole & Parascalops breweri & 0 & 0 & 0 & 0 & 3 & 1 \\
\hline Vespertilionidae & Little Brown Myotis & Myotis lucifugus & 0 & 0 & 0 & 0 & 0 & 1 \\
\hline Vespertilionidae & Long-eared Bat & Myotis septentrionalis & 0 & 0 & 0 & 0 & 0 & 3 \\
\hline Vespertilionidae & Eastern Pipistrelle & Pipistrellus subflavus & 0 & 0 & 0 & 0 & 0 & 1 \\
\hline Vespertilionidae & Big Brown Bat & Eptesicus fuscus & 0 & 0 & 0 & 0 & 1 & 0 \\
\hline
\end{tabular}


Appendix Ib. Continued.

\begin{tabular}{|c|c|c|c|c|c|c|c|c|}
\hline \multirow[b]{2}{*}{ Family } & \multirow[b]{2}{*}{ Common Name } & \multirow[b]{2}{*}{ Scientific Name } & \multicolumn{3}{|c|}{2000} & \multicolumn{3}{|c|}{2001} \\
\hline & & & $\mathrm{BM}$ & $\mathrm{CA}$ & $\mathrm{PT}$ & $\mathrm{BM}$ & $\mathrm{CA}$ & $\mathrm{PT}$ \\
\hline Vespertilionidae & Red Bat & Lasiurus borealis & 0 & 0 & 0 & 0 & 0 & 1 \\
\hline Leporidae & Eastern Cottontail & Sylvilagus floridanus & 0 & 0 & 2 & 0 & 2 & 1 \\
\hline Sciuridae & Woodchuck & Marmota monax & 0 & 0 & 0 & 0 & 1 & 0 \\
\hline Sciuridae & Eastern Chipmunk & Tamias striatus & 2 & 25 & 6 & 8 & 27 & 31 \\
\hline Sciuridae & Eastern Fox Squirrel & Sciurus carolinensis & 0 & 0 & 0 & 0 & 2 & 0 \\
\hline Sciuridae & Red Squirrel & Tamiasciurus hudsonicus & 0 & 0 & 0 & 0 & 1 & 4 \\
\hline Sciuridae & Southern Flying Squirrel & Glaucomys volans & 0 & 5 & 4 & 1 & 3 & 12 \\
\hline Muridae & Deer Mouse & Peromyscus maniculatus & 19 & 44 & 95 & 36 & 39 & 443 \\
\hline Muridae & White-footed Mouse & Peromyscus leucopus & 45 & 204 & 171 & 66 & 279 & 779 \\
\hline Muridae & Allegheny Woodrat & Neotoma magister & 0 & 0 & 13 & 0 & 0 & 3 \\
\hline Muridae & Southern Bog Lemming & Synaptomys cooperi & 12 & 5 & 6 & 5 & 9 & 29 \\
\hline Muridae & Red-backed Vole & Clethrionomys gapperi & 6 & 14 & 14 & 23 & 28 & 131 \\
\hline Muridae & Meadow Vole & Microtus pennsylvanicus & 12 & 28 & 21 & 30 & 74 & 64 \\
\hline
\end{tabular}


Appendix Ib. Continued.

\begin{tabular}{|c|c|c|c|c|c|c|c|c|}
\hline \multirow[b]{2}{*}{ Family } & \multirow[b]{2}{*}{ Common Name } & \multirow[b]{2}{*}{ Scientific Name } & \multicolumn{3}{|c|}{2000} & \multicolumn{3}{|c|}{2001} \\
\hline & & & $\mathrm{BM}$ & $\mathrm{CA}$ & $\mathrm{PT}$ & $\mathrm{BM}$ & $\mathrm{CA}$ & $\mathrm{PT}$ \\
\hline Dipodidae & Meadow Jumping Mouse & Zapus hudsonius & 20 & 222 & 23 & 16 & 78 & 60 \\
\hline Dipodidae & Woodland Jumping Mouse & Napaeozapus insignis & 9 & 57 & 111 & 12 & 81 & 235 \\
\hline Mustelidae & Least Weasel & Mustela rixosa & 0 & 0 & 0 & 1 & 1 & 3 \\
\hline Mustelidae & Long-tailed Weasel & Mustela frenata & 1 & 1 & 1 & 1 & 1 & 1 \\
\hline Mustelidae & Striped Skunk & Mephitis mephitis & 0 & 0 & 2 & 0 & 0 & 0 \\
\hline
\end{tabular}


Appendix IIa. Vegetative characteristics measured at Sherman live trapping grids on the Camp Dawson Collective Training Area in Preston County, West Virginia during 2000 and 2001. Coarse Woody Debris (CWD) volumes are reported before and after manipulation of CWD. ( $\mathrm{A}=$ Addition Site, $\mathrm{R}=$ Removal Site, $\mathrm{C}=$ Control site).

\begin{tabular}{|c|c|c|c|c|c|c|c|c|c|}
\hline $\begin{array}{c}\text { Grid } \\
\text { ID }\end{array}$ & $\begin{array}{c}\text { CWD } \\
\text { Manipulation } \\
\text { Category }\end{array}$ & $\begin{array}{l}\text { CWD } \\
\text { Before } \\
\left(\mathrm{m}^{3} / \mathrm{ha}\right)\end{array}$ & $\begin{array}{l}\text { CWD } \\
\text { After } \\
\left(\mathrm{m}^{3} / \mathrm{ha}\right)\end{array}$ & $\begin{array}{c}\text { Basal } \\
\text { Area } \\
\left(\mathrm{m}^{2} / \mathrm{ha}\right)\end{array}$ & $\begin{array}{l}\text { Rock } \\
\text { Volume } \\
\left(\mathrm{cm}^{3}\right)\end{array}$ & $\begin{array}{l}\text { Litter } \\
\text { Depth } \\
(\mathrm{cm})\end{array}$ & $\begin{array}{c}\% \\
\text { Canopy } \\
\text { Cover }\end{array}$ & $\begin{array}{c}\% \\
\text { Herbaceous } \\
\text { Cover }\end{array}$ & $\begin{array}{c}\text { Height } \\
\text { Herbaceous } \\
\text { Veg. }(\mathrm{m})\end{array}$ \\
\hline 1 & $\mathrm{C}$ & 29.90 & 29.90 & 9.18 & 0 & 0.15 & 95.20 & 90.10 & 0.42 \\
\hline 2 & $\mathrm{R}$ & 30.42 & 15.21 & 6.89 & 0 & 0.42 & 89.92 & 83.37 & 0.31 \\
\hline 3 & $\mathrm{R}$ & 17.72 & 8.86 & 9.18 & 220 & 1.69 & 99.45 & 17.88 & 0.13 \\
\hline 6 & A & 42.02 & 63.03 & 18.36 & 0 & 2.36 & 99.01 & 43.27 & 0.21 \\
\hline 9 & $\mathrm{R}$ & 40.92 & 20.46 & 22.96 & 7390 & 1.94 & 97.59 & 34.08 & 0.30 \\
\hline 10 & $\mathrm{C}$ & 21.54 & 21.54 & 22.96 & 16723 & 0.46 & 99.81 & 55.31 & 0.24 \\
\hline 11 & $\mathrm{C}$ & 104.98 & 104.98 & 18.36 & 0 & 1.01 & 99.82 & 61.33 & 0.25 \\
\hline 15 & $\mathrm{C}$ & 103.26 & 103.26 & 22.96 & 2861 & 0.26 & 99.76 & 34.49 & 0.16 \\
\hline 16 & A & 34.60 & 51.90 & 16.07 & 11819 & 0.25 & 99.30 & 28.47 & 0.44 \\
\hline 22 & $\mathrm{R}$ & 46.64 & 23.32 & 9.18 & 35 & 0.24 & 99.01 & 94.18 & 0.35 \\
\hline 23 & A & 145.14 & 217.71 & 16.07 & 5551 & 0.17 & 99.70 & 56.73 & 0.18 \\
\hline 25 & A & 125.00 & 187.50 & 25.25 & 0 & 0.20 & 98.49 & 81.12 & 0.41 \\
\hline 18 & $\mathrm{R}$ & 21.82 & 10.91 & 9.18 & 681 & 1.40 & 97.07 & 60.12 & 0.40 \\
\hline 26 & A & 24.62 & 36.93 & 25.25 & 829 & 0.70 & 99.40 & 71.63 & 0.28 \\
\hline 27 & $\mathrm{C}$ & 16.26 & 16.26 & 13.77 & 805 & 1.35 & 98.31 & 55.41 & 0.27 \\
\hline 28 & A & 16.90 & 25.35 & 25.25 & 53 & 0.80 & 99.26 & 66.94 & 0.22 \\
\hline 29 & $\mathrm{R}$ & 43.90 & 21.95 & 13.77 & 1205 & 0.97 & 98.71 & 59.17 & 0.24 \\
\hline 30 & $\mathrm{C}$ & 11.72 & 11.72 & 18.36 & 2406 & 1.15 & 99.38 & 58.88 & 0.29 \\
\hline
\end{tabular}


Appendix IIb. Captures per 100 trap nights (CPU) for small mammal species captured in sampling grids stratified by addition $(\underline{\mathrm{N}}=6)$, removal $(\underline{\mathrm{N}}=6)$, and control $(\underline{\mathrm{N}}=6)$ coarse woody debris $(\mathrm{CWD})$ manipulation classes, edge $(\underline{\mathrm{N}}=10)$ and interior $(\underline{\mathrm{N}}=8)$ trapping locations, and riparian $(\underline{\mathrm{N}}=9)$ and upland $(\underline{\mathrm{N}}=9)$ habitats.

\begin{tabular}{|c|c|c|c|c|c|c|c|c|c|c|c|c|c|c|}
\hline \multirow{2}{*}{ Scientific Name } & \multicolumn{6}{|c|}{ CWD Manipulation Category } & \multicolumn{4}{|c|}{ Site Location } & \multicolumn{4}{|c|}{ Habitat Type } \\
\hline & \multicolumn{2}{|c|}{ Addition } & \multicolumn{2}{|c|}{ Removal } & \multicolumn{2}{|c|}{ Control } & \multicolumn{2}{|c|}{ Edge } & \multicolumn{2}{|c|}{ Interior } & \multicolumn{2}{|c|}{ Riparian } & \multicolumn{2}{|c|}{ Upland } \\
\hline Didelphis virginiana & 0.07 & 0.05 & 0.15 & 0.09 & 0.00 & 0.00 & 0.13 & 0.06 & 0.00 & 0.00 & 0.11 & 0.06 & 0.04 & 0.04 \\
\hline$\underline{\text { Sorex cinereus }}$ & 0.16 & 0.08 & 0.00 & 0.00 & 0.17 & 0.09 & 0.04 & 0.03 & 0.21 & 0.09 & 0.09 & 0.06 & 0.13 & 0.06 \\
\hline Sorex fumeus & 0.06 & 0.04 & 0.03 & 0.03 & 0.07 & 0.05 & 0.04 & 0.03 & 0.08 & 0.04 & 0.08 & 0.04 & 0.02 & 0.02 \\
\hline$\underline{\text { Tamiasciurus hudsonicus }}$ & 0.10 & 0.08 & 0.04 & 0.04 & 0.04 & 0.04 & 0.00 & 0.00 & 0.14 & 0.07 & 0.07 & 0.05 & 0.05 & 0.04 \\
\hline Glaucomys volans & 0.33 & 0.09 & 0.31 & 0.12 & 0.28 & 0.14 & 0.30 & 0.09 & 0.32 & 0.10 & 0.19 & 0.07 & 0.43 & 0.12 \\
\hline Peromyscus spp. & 18.63 & 1.58 & 21.38 & 2.83 & 21.63 & 2.60 & 18.73 & 1.87 & 23.05 & 1.98 & 16.09 & 1.26 & 25.01 & 2.32 \\
\hline$\underline{\text { Neotoma magister }}$ & 0.00 & 0.00 & 0.00 & 0.00 & 0.07 & 0.05 & 0.02 & 0.02 & 0.03 & 0.03 & 0.02 & 0.02 & 0.03 & 0.03 \\
\hline Zapus hudsonius & 0.00 & 0.00 & 0.03 & 0.03 & 0.03 & 0.03 & 0.03 & 0.02 & 0.00 & 0.00 & 0.02 & 0.02 & 0.02 & 0.02 \\
\hline Napaeozapus insignis & 0.00 & 0.00 & 0.27 & 0.27 & 0.19 & 0.10 & 0.20 & 0.16 & 0.09 & 0.07 & 0.26 & 0.19 & 0.05 & 0.03 \\
\hline Mustela frenata & 0.06 & 0.04 & 0.00 & 0.00 & 0.00 & 0.00 & 0.02 & 0.02 & 0.02 & 0.02 & 0.00 & 0.00 & 0.04 & 0.03 \\
\hline
\end{tabular}


Appendix IIc. Test values for the interaction terms of coarse woody debris (CWD) by location of trapping grid (edge/interior), CWD by trapping session, and CWD by location by trapping session for captures per 100 trap night (CPU) values of the 5 most abundant species, total CPU, and diversity indices of small mammals captured in addition, removal, and control CWD manipulation trapping grids on the Camp Dawson Collective Training Area in Preston County, West Virginia during 2000 and 2001. Data are from 2 different statistical models.

\begin{tabular}{|c|c|c|c|c|c|c|c|c|c|c|c|c|}
\hline \multirow[b]{3}{*}{ Value } & \multicolumn{6}{|c|}{ Model I } & \multicolumn{6}{|c|}{ Model II } \\
\hline & \multicolumn{2}{|c|}{$\begin{array}{l}\text { CWD by } \\
\text { Location }\end{array}$} & \multicolumn{2}{|c|}{$\begin{array}{c}\text { CWD by } \\
\text { Trapping Session }\end{array}$} & \multicolumn{2}{|c|}{$\begin{array}{l}\text { CWD by Location } \\
\text { by Trapping Session }\end{array}$} & \multicolumn{2}{|c|}{$\begin{array}{l}\text { CWD by } \\
\text { Location }\end{array}$} & \multicolumn{2}{|c|}{$\begin{array}{c}\text { CWD by } \\
\text { Trapping Session }\end{array}$} & \multicolumn{2}{|c|}{$\begin{array}{l}\text { CWD by Location } \\
\text { by Trapping Session }\end{array}$} \\
\hline & $\underline{\mathrm{F}}_{2,30}$ & $\underline{\mathrm{P}}$ & $\underline{F}_{10,30}$ & $\underline{\mathrm{P}}$ & $\underline{\mathrm{F}}_{10,30}$ & $\underline{\mathrm{P}}$ & $\underline{F}_{2,14}$ & $\underline{P}$ & $\underline{F}_{6,14}$ & $\underline{\mathrm{P}}$ & $\underline{\mathrm{F}}_{4,14}$ & $\underline{\mathrm{P}}$ \\
\hline Peromyscus spp. & 1.25 & $0 . \overline{352}$ & 0.61 & $0 . \overline{796}$ & 1.45 & $0 . \overline{206}$ & 0.01 & $0 . \overline{986}$ & 2.63 & 0.064 & 2.22 & 0.12 \\
\hline$\underline{\text { Blarina brevicauda }}$ & 2.51 & 0.161 & 1.51 & 0.184 & 1.06 & 0.42 & 0.01 & 0.986 & 1.27 & 0.332 & 0.82 & 0.534 \\
\hline Clethrionomys gapperi & $12.76^{*}$ & $0.007 *$ & 1.76 & 0.114 & 2.04 & 0.064 & 2.35 & 0.142 & 0.83 & 0.564 & 0.97 & 0.456 \\
\hline$\underline{\text { Tamias striatus }}$ & 1.88 & 0.233 & 1.26 & 0.298 & 1.05 & 0.427 & 1.43 & 0.282 & 0.24 & 0.955 & 0.14 & 0.965 \\
\hline Glaucomys volans & 2.69 & 0.147 & 1.38 & 0.236 & 2.03 & 0.066 & 1.04 & 0.387 & 0.07 & 0.998 & 1.52 & 0.25 \\
\hline Total & 1.81 & 0.243 & 0.91 & 0.533 & 2.01 & 0.07 & 0.01 & 0.991 & 1.13 & 0.396 & 0.84 & 0.52 \\
\hline Species Richness (S) & 2.29 & 0.183 & 0.84 & 0.592 & 0.92 & 0.529 & 1.1 & 0.367 & 0.5 & 0.797 & 2.04 & 0.144 \\
\hline Pielou's Index (J) & 0.41 & 0.682 & 0.56 & 0.832 & 0.55 & 0.839 & 0.37 & 0.698 & 0.2 & 0.972 & 0.65 & 0.596 \\
\hline
\end{tabular}


Appendix IIc. Continued.

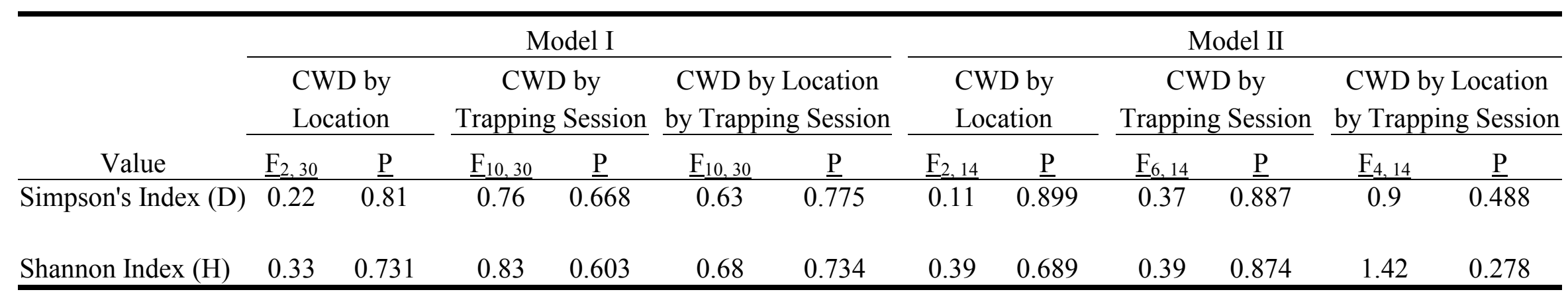


Appendix IId. Test values for the interaction terms of coarse woody debris (CWD) by location of trapping grid (edge/interior), CWD

by trapping session, and CWD by location by trapping session for average mass ( $\mathrm{g}$ ), ratio of males to females, and proportion of

reproductive females of Peromyscus spp. and Blarina brevicauda captured in addition, removal, and control CWD manipulation

trapping grids on the Camp Dawson Collective Training Area in Preston County, West Virginia during 2000 and 2001 . Data are from

2 different statistical models.

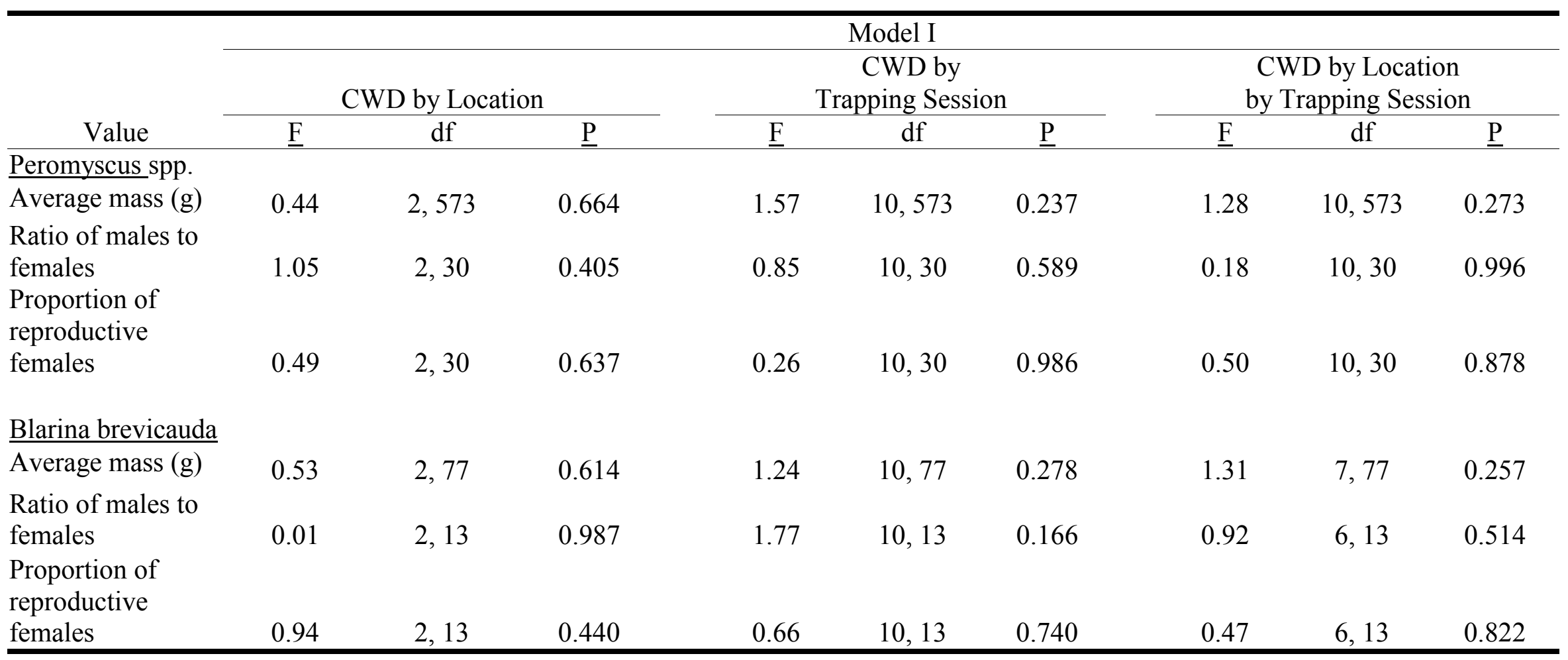


Appendix IId. Continued.

\begin{tabular}{|c|c|c|c|c|c|c|c|c|c|}
\hline \multirow[b]{3}{*}{ Value } & \multicolumn{9}{|c|}{ Model II } \\
\hline & \multicolumn{3}{|c|}{ CWD by Location } & \multicolumn{3}{|c|}{$\begin{array}{c}\text { CWD by } \\
\text { Trapping Session }\end{array}$} & \multicolumn{3}{|c|}{$\begin{array}{l}\text { CWD by Location } \\
\text { by Trapping Session }\end{array}$} \\
\hline & $\underline{F}$ & df & $\underline{\mathrm{P}}$ & $\underline{F}$ & df & $\underline{\mathrm{P}}$ & $\underline{F}$ & df & $\underline{P}$ \\
\hline \multicolumn{10}{|l|}{ Peromyscus spp. } \\
\hline Average mass (g) & 0.93 & 2,395 & 0.424 & 1.99 & 6,395 & 0.096 & 2.03 & 4,395 & 0.089 \\
\hline $\begin{array}{l}\text { Ratio of males to } \\
\text { females }\end{array}$ & 1.44 & 2,14 & 0.278 & 0.20 & 6,14 & 0.970 & 0.12 & 4,14 & 0.975 \\
\hline females & 0.10 & 2,14 & 0.908 & 0.17 & 6,14 & 0.982 & 0.71 & 4,14 & 0.601 \\
\hline \multicolumn{10}{|l|}{$\underline{\text { Blarina brevicauda }}$} \\
\hline Average mass (g) & 0.88 & 2,43 & 0.451 & 1.13 & 6,43 & 0.364 & 1.79 & 1,43 & 0.188 \\
\hline $\begin{array}{l}\text { Ratio of males to } \\
\text { females } \\
\text { Proportion of } \\
\text { reproductive } \\
\text { females }\end{array}$ & 0.15 & 2,5 & 0.863 & 0.25 & 6,5 & 0.942 & 0.47 & 2,5 & 0.648 \\
\hline
\end{tabular}


Appendix IIIa. Average relative abundance in captures per 100 trap nights (CPU) for small mammal species captured in pitfall traps in riparian and upland habitats and edge and interior trapping locations on the Camp Dawson Collective Training Area in Preston County, West Virginia during 2000 and 2001.

\begin{tabular}{|c|c|c|c|c|c|c|c|c|c|}
\hline \multirow[b]{3}{*}{ Common Name } & \multirow[b]{3}{*}{ Scientific Name } & \multicolumn{4}{|c|}{ Habitat } & \multicolumn{4}{|c|}{ Location } \\
\hline & & \multicolumn{2}{|c|}{ Riparian } & \multicolumn{2}{|c|}{ Upland } & \multicolumn{2}{|c|}{ Edge } & \multicolumn{2}{|c|}{ Interior } \\
\hline & & $\mathrm{CPU}$ & SE & $\mathrm{CPU}$ & SE & $\mathrm{CPU}$ & SE & CPU & SE \\
\hline masked shrew & Sorex cinereus & 2.386 & 0.299 & 3.941 & 0.514 & 2.677 & 0.413 & 4.297 & 0.601 \\
\hline smoky shrew & Sorex fumeus & 0.868 & 0.111 & 1.269 & 0.240 & 0.909 & 0.167 & 1.401 & 0.298 \\
\hline long-tailed shrew & Sorex dispar & 0.047 & 0.027 & 0.046 & 0.014 & 0.030 & 0.016 & 0.064 & 0.020 \\
\hline pygmy shrew & Sorex hoyi & 0.000 & 0.000 & 0.013 & 0.008 & 0.002 & 0.002 & 0.017 & 0.012 \\
\hline $\begin{array}{l}\text { northern short-tailed } \\
\text { shrew }\end{array}$ & Blarina brevicauda & 0.538 & 0.088 & 0.900 & 0.126 & 0.754 & 0.109 & 0.810 & 0.153 \\
\hline Hairytail mole & Parascalops breweri & 0.009 & 0.005 & 0.006 & 0.006 & 0.004 & 0.003 & 0.011 & 0.009 \\
\hline star-nosed mole & Condylura cristata & 0.027 & 0.014 & 0.016 & 0.009 & 0.016 & 0.008 & 0.024 & 0.013 \\
\hline eastern cottontail & Sylvilagus floridanus & 0.003 & 0.003 & 0.003 & 0.003 & 0.006 & 0.004 & 0.000 & 0.000 \\
\hline eastern chipmunk & Tamias striatus & 0.223 & 0.109 & 0.079 & 0.026 & 0.114 & 0.036 & 0.142 & 0.078 \\
\hline
\end{tabular}


Appendix IIIa. Continued.

\begin{tabular}{|c|c|c|c|c|c|c|c|c|c|}
\hline \multirow[b]{3}{*}{ Common Name } & \multirow[b]{3}{*}{ Scientific Name } & \multicolumn{4}{|c|}{ Habitat } & \multicolumn{4}{|c|}{ Location } \\
\hline & & \multicolumn{2}{|c|}{ Riparian } & \multicolumn{2}{|c|}{ Upland } & \multicolumn{2}{|c|}{ Edge } & \multicolumn{2}{|c|}{ Interior } \\
\hline & & $\mathrm{CPU}$ & SE & $\mathrm{CPU}$ & SE & CPU & $\mathrm{SE}$ & $\mathrm{CPU}$ & SE \\
\hline southern flying squirrel & Glaucomys volans & 0.003 & 0.003 & 0.001 & 0.001 & 0.004 & 0.003 & 0.000 & 0.000 \\
\hline southern red-backed vole & Clethrionomys gapperi & 0.104 & 0.028 & 0.351 & 0.068 & 0.235 & 0.071 & 0.308 & 0.065 \\
\hline meadow vole & Microtus pennsylvanicus & 0.354 & 0.122 & 0.725 & 0.179 & 0.805 & 0.200 & 0.363 & 0.137 \\
\hline rock vole & Microtus chrotorrhinus & 0.000 & 0.000 & 0.014 & 0.014 & 0.000 & 0.000 & 0.020 & 0.020 \\
\hline woodland vole & Microtus pinetorum & 0.026 & 0.011 & 0.036 & 0.017 & 0.040 & 0.016 & 0.024 & 0.017 \\
\hline southern bog lemming & Synaptomys cooperi & 0.174 & 0.047 & 0.115 & 0.029 & 0.214 & 0.040 & 0.043 & 0.015 \\
\hline Peromyscus spp. & Peromyscus spp. & 1.196 & 0.226 & 2.24 & 0.271 & 1.631 & 0.227 & 2.204 & 0.351 \\
\hline woodland jumping mouse & Napaeozapus insignis & 1.560 & 0.582 & 1.106 & 0.242 & 0.858 & 0.202 & 1.726 & 0.482 \\
\hline meadow jumping mouse & Zapus hudsonius & 1.559 & 0.403 & 1.337 & 0.658 & 1.360 & 0.392 & 1.472 & 0.890 \\
\hline least weasel & Mustela nivalis & 0.000 & 0.000 & 0.010 & 0.007 & 0.011 & 0.008 & 0.002 & 0.002 \\
\hline long-tailed weasel & Mustela frenata & 0.000 & 0.000 & 0.005 & 0.003 & 0.000 & 0.000 & 0.008 & 0.005 \\
\hline
\end{tabular}


Appendix IIIb. Average relative abundance in captures per 100 trap nights (CPU), species richness, Pielou's Evenness Index, and Shannon Diversity Index for small mammal species captured in pitfall traps in riparian edge (RE), riparian interior (RI), upland edge (UE), and upland interior (UI) locations on the Camp Dawson Collective Training Area in Preston County, West Virginia during 2000 and 2001. Test values are for the interaction of habitat (riparian and upland) and location (edge and interior).

\begin{tabular}{|c|c|c|c|c|c|c|c|c|c|c|}
\hline \multirow[b]{2}{*}{ Index } & \multicolumn{2}{|c|}{ RE } & \multicolumn{2}{|c|}{ RI } & \multicolumn{2}{|c|}{ UE } & \multicolumn{2}{|c|}{ UI } & \multirow[b]{2}{*}{$F_{1,56}$} & \multirow[b]{2}{*}{$P$} \\
\hline & mean & SE & mean & SE & mean & SE & mean & SE & & \\
\hline masked shrew & 2.12 & 0.31 & 2.92 & 0.64 & 3.07 & 0.66 & 3.74 & 0.75 & 0.05 & 0.831 \\
\hline Peromyscus spp. & 0.97 & 0.25 & 1.65 & 0.43 & 2.09 & 0.31 & 2.38 & 0.44 & 0.34 & 0.563 \\
\hline smoky shrew & 0.74 & 0.10 & 1.12 & 0.26 & 1.03 & 0.27 & 1.49 & 0.38 & 0.47 & 0.497 \\
\hline woodland jumping mouse & 1.07 & 0.41 & 2.54 & 1.55 & 0.71 & 0.19 & 1.47 & 0.42 & 0.28 & 0.598 \\
\hline northern short-tailed shrew & 0.50 & 0.12 & 0.62 & 0.13 & 0.93 & 0.16 & 0.87 & 0.20 & 0.49 & 0.487 \\
\hline meadow jumping mouse & 1.63 & 0.48 & 1.42 & 0.79 & 1.17 & 0.58 & 1.49 & 1.16 & 0.06 & 0.813 \\
\hline meadow vole & 0.48 & 0.17 & 0.09 & 0.05 & 1.03 & 0.31 & 0.45 & 0.18 & 0.05 & 0.831 \\
\hline southern red-backed vole & 0.09 & 0.03 & 0.13 & 0.07 & 0.34 & 0.11 & 0.36 & 0.08 & 0.11 & 0.742 \\
\hline
\end{tabular}


Appendix IIIb. Continued.

\begin{tabular}{|c|c|c|c|c|c|c|c|c|c|c|}
\hline \multirow[b]{2}{*}{ Index } & \multicolumn{2}{|c|}{ RE } & \multicolumn{2}{|c|}{ RI } & \multicolumn{2}{|c|}{ UE } & \multicolumn{2}{|c|}{ UI } & \multirow[b]{2}{*}{$F_{1,56}$} & \multirow[b]{2}{*}{$P$} \\
\hline & mean & $\mathrm{SE}$ & mean & SE & mean & $\mathrm{SE}$ & mean & SE & & \\
\hline southern bog lemming & 0.23 & 0.06 & 0.05 & 0.03 & 0.20 & 0.05 & 0.04 & 0.02 & 0.10 & 0.749 \\
\hline eastern chipmunk & 0.14 & 0.06 & 0.39 & 0.31 & 0.10 & 0.05 & 0.06 & 0.03 & 0.86 & 0.356 \\
\hline long-tailed shrew & 0.05 & 0.04 & 0.04 & 0.04 & 0.02 & 0.01 & 0.07 & 0.02 & 1.27 & 0.264 \\
\hline Total CPU & 8.10 & 1.47 & 11.09 & 3.27 & 10.79 & 1.31 & 13.53 & 1.59 & 0.03 & 0.863 \\
\hline Species Richness & 9.93 & 0.38 & 9.29 & 0.52 & 8.75 & 0.57 & 8.68 & 0.43 & 0.60 & 0.443 \\
\hline Pielou's Evenness Index & 0.80 & 0.02 & 0.78 & 0.02 & 0.79 & 0.02 & 0.73 & 0.03 & 0.18 & 0.672 \\
\hline Shannon Diversity Index & 1.82 & 0.06 & 1.74 & 0.07 & 1.68 & 0.07 & 1.56 & 0.08 & 0.06 & 0.805 \\
\hline
\end{tabular}


Appendix IIIc. Average mass (g) of the 5 most abundant species captured in pitfall traps in riparian edge (RE), riparian interior (RI), upland edge (UE), and upland interior (UI) locations on the Camp Dawson Collective Training Area in Preston County, West Virginia during 2000 and 2001. Test values are for the interaction of habitat (riparian and upland) and location (edge and interior).

\begin{tabular}{|c|c|c|c|c|c|c|c|c|c|c|c|}
\hline \multirow[b]{2}{*}{ Common Name } & \multicolumn{2}{|c|}{$\mathrm{RE}$} & \multicolumn{2}{|c|}{ RI } & \multicolumn{2}{|c|}{ UE } & \multicolumn{2}{|c|}{ UI } & \multirow[b]{2}{*}{$F$} & \multirow[b]{2}{*}{$d f$} & \multirow[b]{2}{*}{$P$} \\
\hline & mean & SE & mean & SE & mean & SE & mean & SE & & & \\
\hline masked shrew & 4.10 & 0.06 & 4.32 & 0.07 & 4.11 & 0.05 & 4.13 & 0.04 & 0.04 & 1,1344 & 0.838 \\
\hline smoky shrew & 7.28 & 0.17 & 7.63 & 0.19 & 7.06 & 0.13 & 7.29 & 0.13 & 0.61 & 1,506 & 0.436 \\
\hline northern short-tailed shrew & 17.79 & 0.49 & 16.59 & 0.52 & 16.69 & 0.39 & 16.43 & 0.36 & 1.57 & 1,335 & 0.211 \\
\hline Peromyscus spp. & 17.40 & 0.54 & 17.25 & 0.56 & 17.23 & 0.35 & 17.47 & 0.34 & 0.01 & 1,754 & 0.933 \\
\hline woodland jumping mouse & 18.44 & 0.45 & 19.07 & 0.48 & 18.23 & 0.50 & 19.09 & 0.31 & 0.00 & 1,453 & 0.993 \\
\hline
\end{tabular}


Appendix IIId. Ratio of males to females for the 5 most abundant small mammals captured in pitfall traps in riparian edge (RE), riparian interior (RI), upland edge (UE), and upland interior (UI) locations on the Camp Dawson Collective Training Area in Preston County, West Virginia during 2000 and 2001. Test values are for the interaction of habitat (riparian and upland) and location (edge and interior).

\begin{tabular}{|c|c|c|c|c|c|c|c|c|c|c|c|}
\hline \multirow[b]{2}{*}{ Common Name } & \multicolumn{2}{|c|}{$\mathrm{RE}$} & \multicolumn{2}{|c|}{ RI } & \multicolumn{2}{|c|}{ UE } & \multicolumn{2}{|c|}{ UI } & \multirow[b]{2}{*}{$F$} & \multirow[b]{2}{*}{$d f$} & \multirow[b]{2}{*}{$P$} \\
\hline & mean & SE & mean & $\mathrm{SE}$ & mean & SE & mean & $\mathrm{SE}$ & & & \\
\hline masked shrew & 1.26 & 0.22 & 1.32 & 0.25 & 1.07 & 0.17 & 1.51 & 0.16 & 0.65 & 1,56 & 0.424 \\
\hline smoky shrew & 0.82 & 0.18 & 1.53 & 0.35 & 0.67 & 0.21 & 1.32 & 0.21 & 1.36 & 1,48 & 0.250 \\
\hline $\begin{array}{l}\text { northern short-tailed } \\
\text { shrew }\end{array}$ & 0.63 & 0.17 & 2.22 & 1.01 & 1.07 & 0.30 & 1.22 & 0.43 & 1.24 & 1,51 & 0.271 \\
\hline Peromyscus spp. & 1.24 & 0.29 & 4.58 & 2.36 & 1.17 & 0.23 & 1.17 & 0.12 & 0.13 & 1,52 & 0.715 \\
\hline woodland jumping mouse & 1.81 & 0.71 & 1.73 & 0.68 & 0.81 & 0.24 & 0.90 & 0.18 & 0.88 & 1,47 & 0.353 \\
\hline
\end{tabular}


Appendix IIIe. Proportion of reproductive females and test values for the 5 most abundant small mammals captured in pitfall traps in riparian edge (RE), riparian interior (RI), upland edge (UE), and upland interior (UI) locations on the Camp Dawson Collective

Training Area in Preston County, West Virginia during 2000 and 2001. Test values are for the interaction of habitat (riparian and

upland) and location (edge and interior). Different letters represent statistical difference for that comparison $(\alpha=0.05)$.

\begin{tabular}{|c|c|c|c|c|c|c|c|c|c|c|c|}
\hline \multirow[b]{2}{*}{ Common Name } & \multicolumn{2}{|c|}{$\mathrm{RE}$} & \multicolumn{2}{|c|}{ RI } & \multicolumn{2}{|c|}{ UE } & \multicolumn{2}{|c|}{ UI } & \multirow[b]{2}{*}{$F$} & \multirow[b]{2}{*}{$d f$} & \multirow[b]{2}{*}{$P$} \\
\hline & mean & SE & mean & $\mathrm{SE}$ & mean & $\mathrm{SE}$ & mean & SE & & & \\
\hline masked shrew & 0.08 & 0.03 & 0.05 & 0.03 & 0.07 & 0.02 & 0.04 & 0.01 & 0.10 & 1,56 & 0.749 \\
\hline smoky shrew & 0.08 & 0.04 & 0.08 & 0.03 & 0.06 & 0.03 & 0.07 & 0.03 & 0.07 & 1,48 & 0.789 \\
\hline northern short-tailed shrew & 0.05 & 0.03 & 0.14 & 0.14 & 0.05 & 0.02 & 0.11 & 0.06 & 0.52 & 1,51 & 0.474 \\
\hline Peromyscus spp. & $0.14 \mathrm{a}$ & 0.04 & $0.00 \mathrm{~b}$ & 0.00 & $0.11 \mathrm{a}$ & 0.03 & $0.08 \mathrm{a}$ & 0.02 & $7.66^{*}$ & 1,52 & $0.008^{*}$ \\
\hline woodland jumping mouse & 0.24 & 0.09 & 0.07 & 0.03 & 0.04 & 0.02 & 0.11 & 0.06 & 1.81 & 1,47 & 0.185 \\
\hline
\end{tabular}

